\title{
Reevaluation of 1999 Health-Based Environmental Screening Levels (HBESLs) for Chemical Warfare Agents
}

May 2007

Prepared by

Toxicology and Hazard Assessment Group

Environmental Sciences Division
A. P. Watson ${ }^{1}$
F. G. Dolislager ${ }^{2}$
${ }^{1}$ Distinguished Research Scientist
${ }^{2}$ Senior Research Associate

Approved for public release; distribution is unlimited

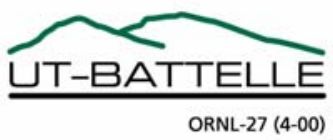




\section{DOCUMENT AVAILABILITY}

Reports produced after January 1, 1996, are generally available free via the U.S. Department of Energy (DOE) Information Bridge.

Web site http://www.osti.gov/bridge

Reports produced before January 1, 1996, may be purchased by members of the public from the following source.

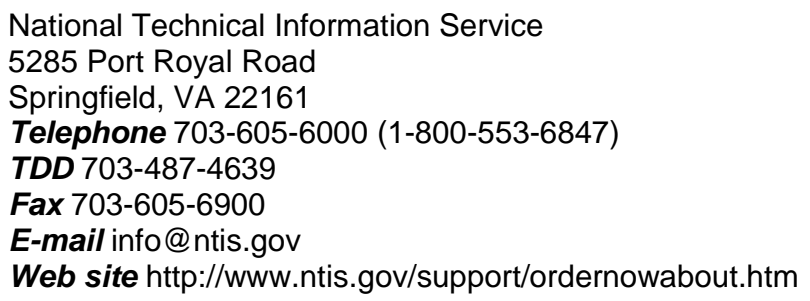

Reports are available to DOE employees, DOE contractors, Energy Technology Data Exchange (ETDE) representatives, and International Nuclear Information System (INIS) representatives from the following source.

Office of Scientific and Technical Information

P.O. Box 62

Oak Ridge, TN 37831

Telephone 865-576-8401

Fax 865-576-5728

E-mail reports@osti.gov

Web site http://www.osti.gov/contact.html

This report was prepared as an account of work sponsored by an agency of the United States Government. Neither the United States Government nor any agency thereof, nor any of their employees, makes any warranty, express or implied, or assumes any legal liability or responsibility for the accuracy, completeness, or usefulness of any information, apparatus, product, or process disclosed, or represents that its use would not infringe privately owned rights. Reference herein to any specific commercial product, process, or service by trade name, trademark, manufacturer, or otherwise, does not necessarily constitute or imply its endorsement, recommendation, or favoring by the United States Government or any agency thereof. The views and opinions of authors expressed herein do not necessarily state or reflect those of the United States Government or any agency thereof. 
Environmental Sciences Division

\title{
REEVALUATION OF 1999 HEALTH-BASED ENVIRONMENTAL SCREENING LEVELS (HBESLS) FOR CHEMICAL WARFARE AGENTS
}

\author{
A. P. Watson \\ Environmental Sciences Division \\ Oak Ridge National Laboratory \\ F. G. Dolislager \\ The Institute for Environmental Modeling \\ University of Tennessee \\ Knoxville, Tennessee
}

May 2007

Prepared for the

U.S. Department of the Army

Under

DOE Proposal No. 2207-M135-A1

\author{
U.S. Army Project Officer: V. Haushchild \\ Directorate of Occupational and Environmental Medicine \\ U.S. Army Center for Health Promotion and Preventive Medicine \\ Aberdeen Proving Ground, Maryland \\ Prepared by \\ OAK RIDGE NATIONAL LABORATORY \\ Oak Ridge, Tennessee 37831-6283 \\ managed by \\ UT-BATTELLE, LLC \\ for the \\ U.S. DEPARTMENT OF ENERGY \\ under contract DE-AC05-00OR22725
}





\section{CONTENTS}

Page

LIST OF TABLES

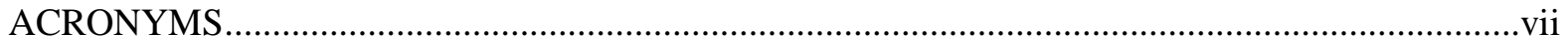

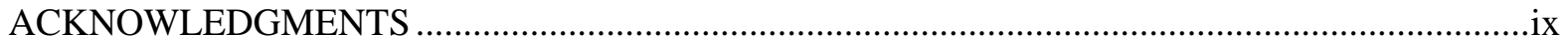

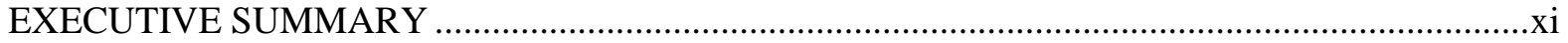

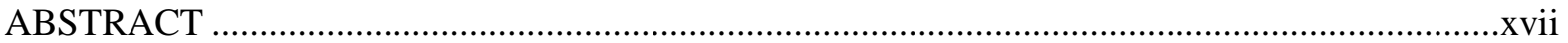

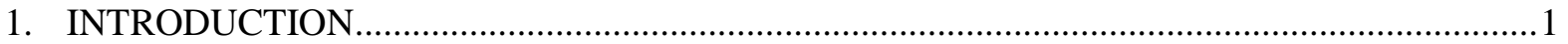

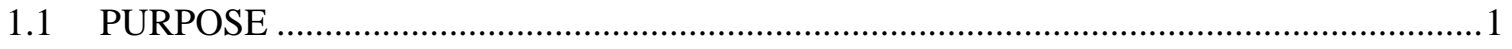

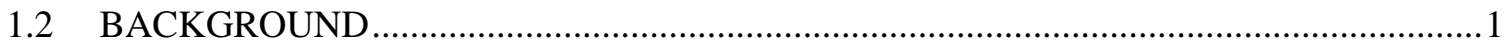

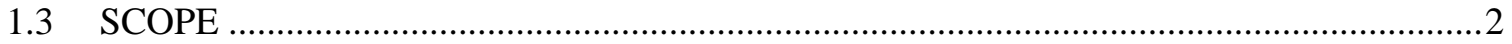

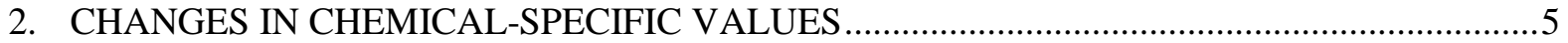

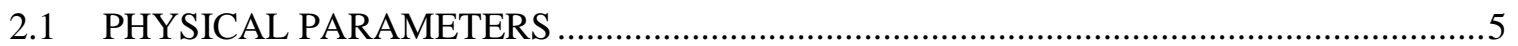

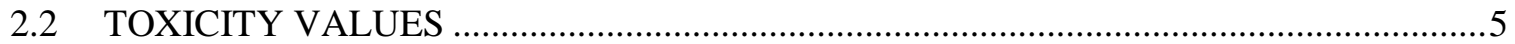

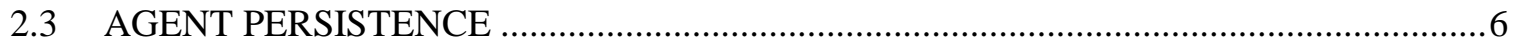

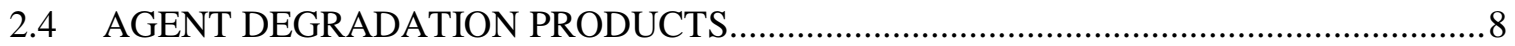

3. CHANGES TO EPA EXPOSURE PARAMETERS AND MODELS …...............................13

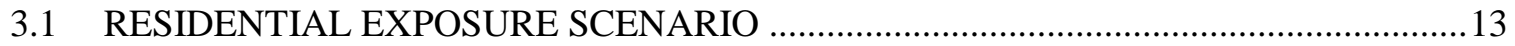

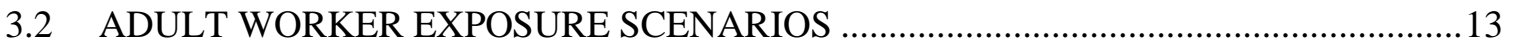

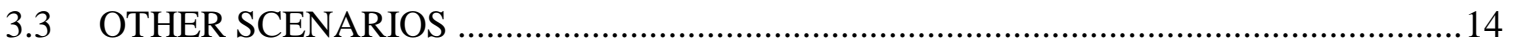

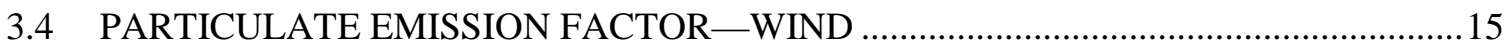

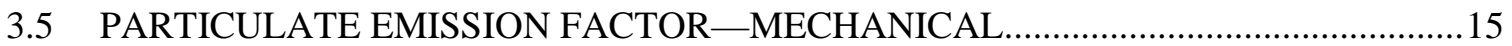

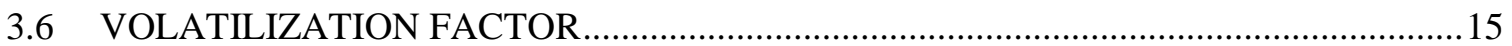

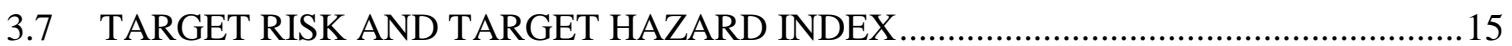

4. COMPARISON OF RESULTING SCREENING VALUES WITH 1999 HBESLS ...................17

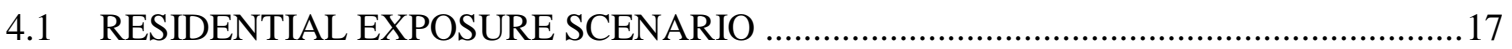

4.2 ADULT WORKER EXPOSURE SCENARIOS …......................................................... 17

5. PRESENTATION OF DEGRADATION PRODUCT SCREENING LEVEL ESTIMATES .....21

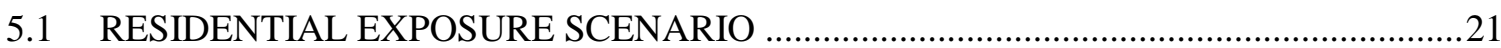

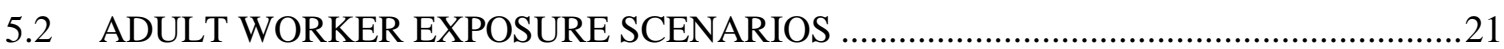

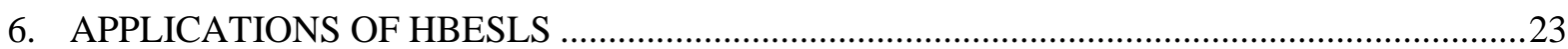

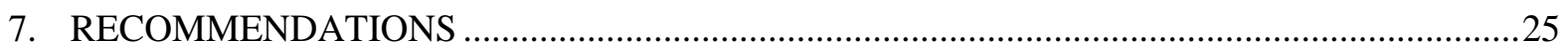

7.1 RECOMMENDATIONS REGARDING EPA CHEMICAL PRG EQUATIONS ..............25

7.2 RECOMMENDATIONS OF 1999 HBESLS OVER THE 2007 SCREENING LEVEL

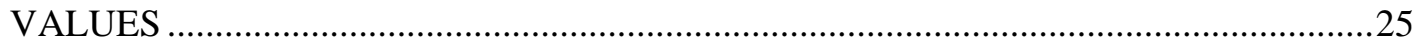

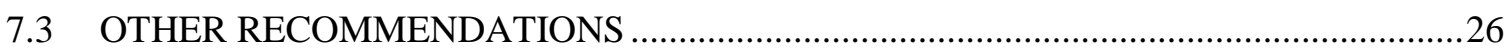

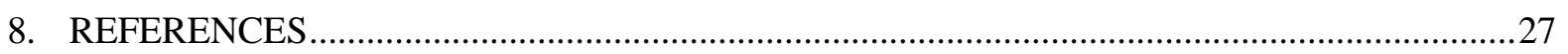

Appendix A. 1999 REGIONAL, OSWER, AND HBESL SCREENING VALUES .......................A-1

Appendix B. FIELD DRINKING WATER CRITERIA AND AIR EXPOSURE GUIDELINE

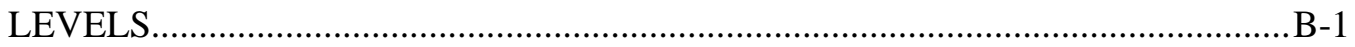

Appendix C. AGENT AND DEGRADATION PRODUCT PHYSICAL, CHEMICAL, AND ENVIRONMENTAL PARAMETERS ………....................................................

Appendix D. LAND USE EQUATIONS AND EXPOSURE PARAMETERS ............................... 



\section{LIST OF TABLES}

Table

Page

ES.1 1999 USACHPPM Region IX PRG Health-Based Environmental Screening Levels (HBESLs) compared to current recalculated screening values ...........................................ii

ES.2 Key CWA breakdown products and associated toxicity and screening levels.................xiii

$1 \quad$ Comparison of 1999 to $2007 \mathrm{CW}$ toxicity values ........................................................ 3

2 Principal chemical warfare agent degradation products of concern, with associated

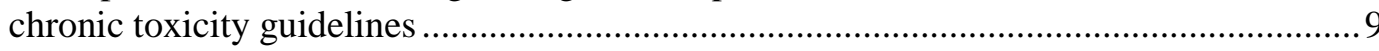

3 Proposed arsenic soil screening level estimates for cancer and noncancer following

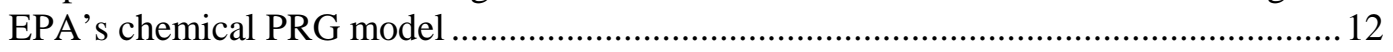

$4 \quad$ Summary of residential soil screening level estimates................................................. 17

$5 \quad$ Summary of outdoor worker soil screening level estimates........................................... 18

$6 \quad$ Summary of indoor worker soil screening level estimates........................................... 18

$7 \quad$ Summary of residential soil screening level estimates...............................................2 21

$8 \quad$ Summary of outdoor worker soil screening level estimates.......................................21

$9 \quad$ Summary of indoor worker soil screening level estimates.........................................22

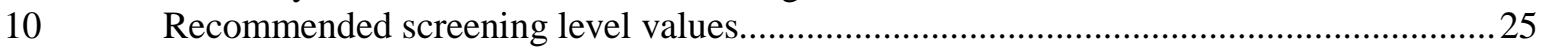

A.1 Summary of previous screening level values ..................................................... A-3

B.1 DOD and international military potable field water quality standards ......................... B-3

B.2 Comparison of chemical warfare Acute Exposure Guideline Levels (AEGLs) with

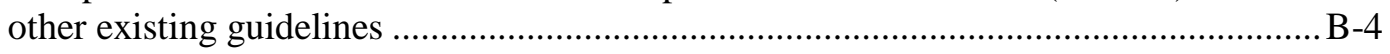

C.1 Physical, chemical, and environmental properties of chemical warfare agents .............. C-3

C.2 Some physical properties of selected chemical warfare agent degradation products ...... C-5

D.1 Residential soil exposure parameters …..................................................................

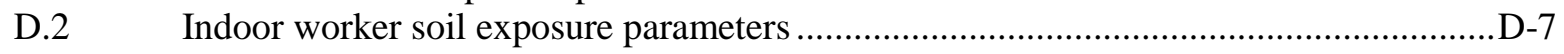

D.3 Outdoor worker soil exposure parameters ................................................................

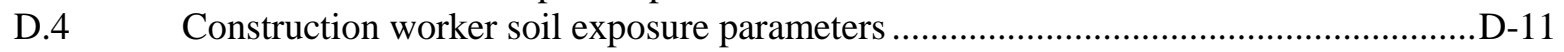

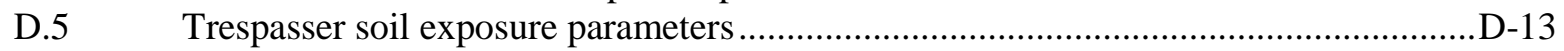

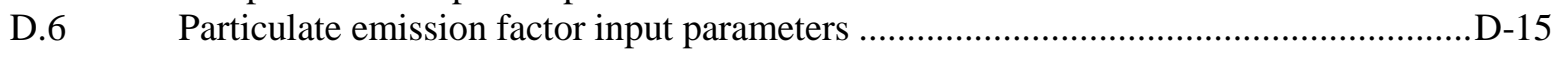

D.7 Volatilization factor input parameters ................................................................... 



\section{ACRONYMS}

ATSDR

CDC

$\mathrm{COPC}$

CSEPP

CWA

DESH

DHHS

DA

EA 2192

ED

EMPA

EPA

FUDS

GA

GB

GC/MS

GD

GF

GPL

HBESL

HD

HQDA

IMPA

IRIS

IUR

L

MPA

NRC

ORNL

OSWER

OTSG

PEF

PRG

RAGS

RAIS

RBC

RfC

RfD

$\mathrm{RfD}_{\mathrm{e}}$

SF

SSL
Agency for Toxic Substances and Disease Registry (USDHHS)

Centers for Disease Control and Prevention (USDHHS)

Contaminants of Potential Concern (Committee of the World Trade Center

Indoor Task Force Working Group)

Chemical Stockpile Emergency Preparedness Program (a joint program of

FEMA and U.S. Department of the Army)

chemical warfare agent(s)

diisopropylaminoethyl mercaptoamine (a degradation product of nerve agent VX)

U.S. Department of Health and Human Services

U.S. Department of the Army

O-Ethyl-S-(diisopropylaminoethyl)methylphosphonothioate (a degradation product of nerve agent VX)

exposure duration (years)

ethyl methyl phosphonic acid (a degradation product of nerve agent VX)

U.S. Environmental Protection Agency

formerly used defense sites

tabun; a nerve agent (CAS No. 77-81-6)

sarin; a nerve agent (CAS No. 107-44-8)

gas chromatographic mass spectrometry

soman; a nerve agent (CAS No. 96-64-0)

cyclosarin, a nerve agent (CAS No. 329-99-7)

general population levels $\left(\mathrm{mg} / \mathrm{m}^{3}\right)(\mathrm{DHHS} / \mathrm{CDC})$

Health-Based Environmental Screening Level

sulfur mustard; a vesicant agent (CAS No. 505-60-2)

headquarters, U.S. Department of the Army

isopropyl methylphosphonic acid (degradation product of nerve agent GB)

Integrated Risk Information System (EPA)

inhalation unit risk (inverse units; per $\mu \mathrm{g} / \mathrm{m}^{3}$ or similar)

Lewisite; an organic arsenical vesicant agent (CAS No. 541-25-3)

methyl phosphonic acid (a degradation product of nerve agents GB, GD, and $\mathrm{VX}$ )

National Research Council

Oak Ridge National Laboratory (Oak Ridge, Tennessee)

Office of Solid Waste and Emergency Response (EPA)

Office of the (Army) Surgeon General

particulate emission factor $\left(\mathrm{PEF}_{\mathrm{w}}\right.$ for wind-driven; $\mathrm{PEF}_{\mathrm{m}}$ for mechanically

driven; EPA)

preliminary remediation goal (EPA Region IX)

Risk Assessment Guidance (EPA)

Risk Assessment Information System (EPA)

risk-based concentration (EPA Region III)

reference concentration $\left(\mathrm{mg} / \mathrm{m}^{3} / \mathrm{d} ; \mathrm{EPA}\right)$

reference dose $(\mathrm{mg} / \mathrm{kg} / \mathrm{d}$ or $\mu \mathrm{g} / \mathrm{kg} / \mathrm{d}$; EPA)

estimated reference dose $(\mathrm{mg} / \mathrm{kg} / \mathrm{d}$ or $\mu \mathrm{g} / \mathrm{kg} / \mathrm{d})$

slope factor (inverse units; per $\mathrm{mg} / \mathrm{kg} / \mathrm{d}$ )

soil screening level (EPA OSWER) 
USACHPPM U.S. Army Center for Health Promotion and Preventive Medicine (HQ at Aberdeen Proving Ground, Maryland)

USAF U.S. Air Force

VF

volatilization factor (EPA)

$\mathrm{VX}$

a nerve agent (CAS No. 50782-69-9) 


\section{ACKNOWLEDGMENTS}

This work was prepared under U.S. Department of Energy Proposal No. 2207-M135-A1 with the U.S. Army Center for Health Promotion and Preventive Medicine (USACHPPM) of Aberdeen Proving Ground, Maryland. The Oak Ridge National Laboratory (ORNL) is managed and operated by UT-Battelle, LLC, for the U.S. Department of Energy under contract DE-AC05-00OR22725.

The authors wish to acknowledge the contributory authorship provided by Veronique Hauschild of the USACHPPM. The authors further acknowledge the sound technical advice, review, and analyses provided by Dennis Opresko of the Environmental Sciences Division of Oak Ridge National Laboratory; Matthew McAtee and Joleen Johnson of USACHPPM; and Debra Stewart of the University of Tennessee Institute for Environmental Modeling in Knoxville, Tennessee.

The views expressed in this document do not necessarily represent official Federal agency position or policy. Mention of trade names or commercial products does not constitute endorsement or recommendation of use. 



\section{EXECUTIVE SUMMARY}

\section{PURPOSE}

The purpose of this report is to determine whether new information and updated scientific models require that changes be made to previously published health-based environmental screening levels (HBESLs) and associated environmental fate/breakdown information for chemical warfare agents (CWAs); soil (USACHPPM 1999). Specifically, the present evaluation describes changes that have been made since 1999 to U.S. Environmental Protection Agency (EPA) risk assessment models, EPA exposure assumptions, as well as to specific CWA parameters (e.g., toxicity values), and compares recalculated screening value estimates to the 1999 HBESLs.

The HBESLs for sulfur mustard (HD), Lewisite (L), Tabun (GA), Sarin (GB), Soman (GD), and VX were documented in the USACHPPM's 1999 report Derivation of Health-Based Environmental Screening Levels for Chemical Warfare Agents (USACHPPM 1999). The USACHPPM (1999) report was endorsed by the Headquarters of the Department of the Army as the current state of science and Army standard practice for investigation and assessment of environmental media potentially contaminated with CWA (HQDA 1999).

The HBESLs are similar to soil screening levels developed by the EPA for industrial chemicals and radionuclides [e.g., EPA Region IX Preliminary Remediation Goals (PRGs); see http://www.epa.gov/region09/waste/sfund/prg/index.html]. Screening levels are used to evaluate whether or not potentially contaminated soils need to be remediated or a site-specific risk evaluation should be performed. They may also be used to determine if an area has been adequately cleaned. These screening levels are based on general assumptions (such as for a residential scenario or an area limited to adult workers i.e., "industrial scenario") and therefore do not reflect site-specific exposure conditions.

\section{FINDINGS}

With the exception of HD for the resident and Lewisite for the indoor worker, the recalculated (2007) values do not vary by more than an order of magnitude from the previously published (1999) HBESLs (Table ES.1). This is particularly true for the recalculated residential soil values for nerve agents GA, GB, GD/GF, and VX, which are essentially identical to the 1999 residential (PRG-based) HBESLs for the same agents (see Table ES.1). The variation seen in residential HD values is the result of an updated inhalation unit risk toxicity value. The variation seen in residential Lewisite values is a result of EPA changes in dermal assessment exposure parameters.

The variation seen in Lewisite values between the 2007 indoor and outdoor worker scenarios is due to omission of the dermal route for the indoor worker in current EPA models. The new EPA approach to worker scenarios is to provide two separate models - one for indoor workers and one for outdoor workers. The 1999 worker (industrial) HBESLs fall within the range of the worker values calculated using these separate indoor and outdoor worker scenario models. The range of values between the 2007 indoor and outdoor worker scenarios is generally within an order of magnitude, a difference within the defined confidence level of the underlying toxicity values. As indicated in USACHPPM (1999), at such estimated Lewisite exposure levels for the indoor worker, the potential for acute effects is a concern. Therefore, the previous (USACHPPM 1999) HBESLs for Lewisite are considered to be more appropriate and protective screening criteria. 
Table ES.1. 1999 USACHPPM Region IX PRG Health-Based Environmental Screening Levels (HBESLs) compared to current recalculated screening values ${ }^{a}$ (two significant figures)

\begin{tabular}{llccccc}
\hline Agent & CAS No. & $\begin{array}{c}\mathbf{1 9 9 9} \\
\text { Residential } \\
\text { soil PRG } \\
\text { HBESL } \\
(\mathbf{m g} / \mathbf{k g})\end{array}$ & $\begin{array}{c}\mathbf{2 0 0 7} \\
\text { Residential } \\
\text { soil } \\
\text { calculation } \\
(\mathbf{m g} / \mathbf{k g})\end{array}$ & $\begin{array}{c}\mathbf{1 9 9 9} \\
\text { Industrial } \\
\text { (outdoor } \\
\text { worker) soil } \\
\text { PRG HBESL } \\
(\mathbf{m g} / \mathbf{k g})\end{array}$ & $\begin{array}{c}\text { 2007 Indoor } \\
\text { worker soil } \\
\text { calculation } \\
(\mathbf{m g} / \mathbf{k g})\end{array}$ & $\begin{array}{c}\text { 2007 Outdoor } \\
\text { worker soil } \\
\text { calculation } \\
\text { (mg/kg) }\end{array}$ \\
\hline HD & $\mathbf{5 0 5 - 6 0 - 2}$ & $\mathbf{0 . 0 1}$ & $0.19^{c}$ & $\mathbf{0 . 3 ^ { b }}$ & $1.4^{c}$ & $1.4^{c}$ \\
L & $\mathbf{5 4 1 - 2 5 - 3}$ & $\mathbf{0 . 3}$ & 0.45 & $\mathbf{3 . 7}$ & 204 & 2.9 \\
GA & $\mathbf{7 7 - 8 1 - 6}$ & $\mathbf{2 . 8}$ & 2.9 & $\mathbf{6 8}$ & 79 & 39 \\
GB & $\mathbf{1 0 7 - 4 4 - 8}$ & $\mathbf{1 . 3}$ & 1.4 & $\mathbf{3 2}$ & 40 & 19 \\
GD/GF & $\mathbf{9 6 - 6 4 - 0}$ & $\mathbf{0 . 2 2}$ & 0.25 & $\mathbf{5 . 2}$ & 8.1 & 3.2 \\
VX & $\mathbf{5 0 7 8 2 - 6 9 - 9}$ & $\mathbf{0 . 0 4 2}$ & 0.043 & $\mathbf{1 . 1}$ & 1.2 & 0.60 \\
\hline
\end{tabular}

${ }^{a}$ The USACHPPM (1999) report included HBESLs calculated from three different EPA risk models: EPA Region III risk-based concentrations (RBCs), EPA Region IX PRGs, and Office of Solid Waste and Emergency Response (OSWER) soil screening levels (SSLs). Currently the EPA has moved toward a single 'national' risk model similar to the EPA Region IX PRG model. The "national" PRG model, developed by the National Screening Table Working Group, is used in the new (2007) level screening HBESL estimates summarized above. This model is currently implemented for radiation exposure estimates and is under active consideration for application in chemical exposure assessments.

${ }^{b} 1999$ PRG estimates were based on cancer endpoint; HD inhalation unit risk utilized in 1999 was $8.5 \times 10^{-2}$ per $\mu \mathrm{g} / \mathrm{m}^{3}$ (from EPA 1991a) with associated inhalation SF of 300 per $\mathrm{mg} / \mathrm{kg} / \mathrm{d}$; target cancer risks were $10^{-5}$ for residential and $10^{-4}$ for industrial and workers.

${ }^{c} 2007$ PRG estimates include results of derivations assuming noncancer endpoints. With an updated HD inhalation unit risk of $4.1 \times 10^{-3}$ per $\mu \mathrm{g} / \mathrm{m}^{3}$ (from USACHPPM 2000a) and associated inhalation SF of $14.35 \mathrm{per} \mathrm{mg} / \mathrm{kg} / \mathrm{d}$ (USACHPPM 2000a; NRC 2003); target cancer risks were $10^{-5}$ for residential and $10^{-4}$ for industrial workers. The resulting "cancer" PRG estimates were $0.185 \mathrm{mg} / \mathrm{kg}$ for resident, $5.1 \mathrm{mg} / \mathrm{kg}$ for indoor worker, and $5.06 \mathrm{mg} / \mathrm{kg}$ for outdoor worker. The resulting noncancer PRG estimates were $0.233 \mathrm{mg} / \mathrm{kg}$ for the resident child, $1.44 \mathrm{mg} / \mathrm{kg}$ for indoor worker, and $1.36 \mathrm{mg} / \mathrm{kg}$ for outdoor worker. The most protective estimates are presented in Table ES.1 (e.g., for sulfur mustard agent, cancer estimate for resident, noncancer estimates for workers).

The 2007 screening value evaluation followed standard EPA protocol and incorporated exposure assumptions for the EPA standard equations. For residential cancer estimates, the EPA standard equation employs an age-adjusted protocol that incorporates exposure assumptions for child and adult; it is noted that the only carcinogens present in the current analysis were the vesicant agent HD and the arsenic degradation product of vesicant agent Lewisite; both cancer and noncancer screening values were calculated for HD and arsenic. For residential noncancer estimates, the EPA standard equation employs a protocol of exposure assumptions for the child only, which EPA has defined as a protective assumption for noncancer screening estimation [see Eqs. (1) and (2) of Appendix D]. Results assuming exposure to a child resident (noncancer) and age-adjusted resident (cancer) are those presented in summary tables of the present report. For sulfur mustard and arsenic, which possess both carcinogenic and non-carcinogenic properties, the most protective exposure estimate has been selected (see Tables ES.1 and ES.2).

The current evaluation does not significantly change key findings about CWA persistence or key CWA breakdown products as described in the USACHPPM (1999) report. Specifically, the primary CWA breakdown products of potential significance during environmental investigations remain the same. There are some modifications to the recommended toxicity criteria for these breakdown products, based on recent literature (Table ES.2). 
Table ES.2. Key CWA breakdown products and associated toxicity and screening levels

\begin{tabular}{|c|c|c|c|c|c|c|c|}
\hline Agent & $\begin{array}{c}\text { Key } \\
\text { breakdown } \\
\text { product(s) }\end{array}$ & $\begin{array}{c}\text { Current } \\
\text { estimated } \\
\text { oral RfD } \\
(\mathbf{m g} / \mathbf{k g} / \mathbf{d})\end{array}$ & $\begin{array}{c}\text { Current } \\
\text { estimated } \\
\text { inhalation } \\
\text { RfD } \\
(\mathrm{mg} / \mathrm{kg} / \mathrm{d})^{\mathbf{a}}\end{array}$ & $\begin{array}{c}\text { Current } \\
\text { estimated } \\
\text { inhalation } \\
\text { RfC } \\
\left(\mathbf{m g} / \mathbf{m}^{3}\right)\end{array}$ & $\begin{array}{c}\text { Estimated } \\
\text { residential } \\
\text { soil screening } \\
\text { level } \\
(\mathrm{mg} / \mathrm{kg})\end{array}$ & $\begin{array}{c}\text { Estimated } \\
\text { outdoor } \\
\text { worker/adult } \\
\text { soil screening } \\
\text { level } \\
(\mathrm{mg} / \mathrm{kg})\end{array}$ & $\begin{array}{c}\text { Estimated } \\
\text { indoor } \\
\text { worker/ } \\
\text { adult soil } \\
\text { screening } \\
\text { level (mg/kg) }\end{array}$ \\
\hline HD & Thiodiglycol & $4.0 \times 10^{-1^{b}}$ & $1.3 \times 10^{-1}$ & $4.7 \times 10^{-1} b$ & $2.4 \times 10^{4}$ & $6.0 \times 10^{4}$ & $8.2 \times 10^{5}$ \\
\hline \multirow[t]{2}{*}{$\mathrm{L}$} & $\begin{array}{l}\text { Lewisite } \\
\text { oxide }\end{array}$ & $1.0 \times 10^{-4^{c}}$ & $3.1 \times 10^{-5}$ & $1.1 \times 10^{-4^{c}}$ & $6.1 \times 10^{0}$ & $1.5 \times 10^{1}$ & $2.0 \times 10^{2}$ \\
\hline & Arsenic & $3.0 \times 10^{-4^{d}}$ & None & None & $3.9 \times 10^{0^{e}}$ & $1.8 \times 10^{2^{f}}$ & $3.8 \times 10^{2^{f}}$ \\
\hline GA & None & & & & & & \\
\hline GB & IMPA & $1.0 \times 10^{-1^{c}}$ & $3.1 \times 10^{-2}$ & $1.1 \times 10^{-1^{c}}$ & $6.1 \times 10^{3}$ & $1.5 \times 10^{4}$ & $2.0 \times 10^{5}$ \\
\hline $\begin{array}{l}\mathrm{GB}, \mathrm{GD}, \\
\mathrm{VX}\end{array}$ & MPA & $2.0 \times 10^{-2^{c}}$ & $6.9 \times 10^{-3}$ & $2.4 \times 10^{-2^{c}}$ & $1.2 \times 10^{3}$ & $3.0 \times 10^{3}$ & $4.1 \times 10^{4}$ \\
\hline \multirow[t]{2}{*}{ VX } & EMPA & $2.8 \times 10^{-2^{c}}$ & $9.7 \times 10^{-3}$ & $3.4 \times 10^{-2^{c}}$ & $1.7 \times 10^{3}$ & $4.2 \times 10^{3}$ & $5.7 \times 10^{4}$ \\
\hline & EA-2192 & $6.0 \times 10^{-7^{c}}$ & $2.0 \times 10^{-7}$ & $7.0 \times 10^{-7^{c}}$ & $4.7 \times 10^{-2}$ & $6.8 \times 10^{-1}$ & $1.2 \times 10^{0}$ \\
\hline
\end{tabular}

${ }^{a}$ Derived from estimated inhalation RfC (USACHPPM 1999; Appendix F, Table 3, p. F-18) and the conversion formula RfD ${ }_{i}$ $(\mathrm{mg} / \mathrm{kg} / \mathrm{d})=\mathrm{RfC}_{\mathrm{i}}\left(\mathrm{mg} / \mathrm{m}^{3}\right) /\left(70 \mathrm{~kg} / 20 \mathrm{~m}^{3}\right)(\mathrm{EPA} 1989 ; \mathrm{EPA} 1991 \mathrm{c})$. Estimated inhalation $\mathrm{RfD}_{\mathrm{i}}$ for TDG derived from current estimated RfD of $0.4 \mathrm{mg} / \mathrm{kg} / \mathrm{da}$ (Reddy et al. 2005) and conversion formula $\mathrm{RfC}_{\mathrm{i}}\left(\mathrm{mg} / \mathrm{m}^{3}\right)=(\mathrm{RfD} \mathrm{mg} / \mathrm{kg} / \mathrm{d} \times 70 \mathrm{~kg}) /\left(20 \mathrm{~m}{ }^{3} \times \mathrm{UF}\right.$ of 3) from USACHPPM (1999; Appendix F, p. F-8).

${ }^{b}$ From Reddy et al. 2005.

${ }^{c}$ From USACHPPM (1999; Appendix F, Table 3, p. F-18).

${ }^{d}$ EPA (2005a; IRIS).

${ }^{e}$ Target cancer risks were $10^{-5}$ for residential. The resulting arsenic cancer PRG soil screening estimate was $3.89 \mathrm{mg} / \mathrm{kg}$ for resident child while the arsenic noncancer PRG soil screening estimate was $21.6 \mathrm{mg} / \mathrm{kg}$ for resident child. The most protective PRG soil screening estimate is for cancer in the resident child and is presented in Table ES.2 above.

${ }^{f}$ Target cancer risks were $10^{-4}$ for workers. For indoor adult workers, the resulting arsenic cancer PRG soil screening estimate was $380 \mathrm{mg} / \mathrm{kg}$, while the arsenic noncancer PRG soil screening estimate was $613 \mathrm{mg} / \mathrm{kg}$. The most protective indoor worker PRG soil screening estimate is thus for cancer and is presented in Table ES.2 above. For outdoor adult workers, the resulting arsenic cancer PRG soil screening estimate was $177 \mathrm{mg} / \mathrm{kg}$, while the arsenic noncancer PRG soil screening estimate was $284 \mathrm{mg} / \mathrm{kg}$. The most protective outdoor worker PRG soil screening estimate is thus for cancer and is presented in Table ES.2 above.

Finally, as emphasized in the USACHPPM 1999 report, HBESLs are based on an assumption of long- term continuous (chronic) exposures. The risk assessor should consider the likelihood of CWA persistence in the environmental setting, as the use of chronic CWA toxicity values and resulting screening levels such as these soil HBESL estimates is not always scientifically supported for every environmental scenario. For some CW agents such as Sarin (GB), volatility and overall environmental degradation is so rapid that long-term exposures are not generally considered to be a realistic concern. That said, while few situations might truly present a chronic CWA exposure, the use of HBESLs to assess limited soil/concrete samples [in conjunction with air monitoring and possible other samples (e.g., wipe samples)] has been documented as a reasonable strategy to provide public assurance that there are no residual hazards with potential to cause some long-term, low-level risk.

\section{CONCLUSIONS AND RECOMMENDATIONS}

The combined effect of updates and/or changes to EPA risk models, EPA default exposure parameters, and certain CWA toxicity criteria does not result in significant alteration to the USACHPPM (1999) HBESL estimates for nerve agents GA, GB, GD/GF, and VX or the vesicant agents HD and L. Given that EPA's final position on separate Tier 1 screening levels for indoor and outdoor worker screening assessments has not yet been released as of May 2007, the authors find that the 1999 HBESL 
estimates shown in Table ES.1 are still appropriate and protective for screening residential as well as nonresidential sites. As such, risk management decisions made on the basis of USACHPPM (1999) recommendations do not require reconsideration. While the 1999 HBESL values are appropriate for continued use as general screening criteria, the updated "2007" estimates (presented below) that follow new EPA protocols currently under development are also protective. When EPA finalizes and documents a position on the matter of indoor and outdoor worker screening assessments, site-specific risk assessments should make use of modified models and criteria.

Specifically, outdoor worksites involving heavy vehicular activity in or around soil or dust as well as indoor worksites downwind from heavy vehicular activity over soil may require site-specific evaluation. To assist in assessing such difficult sites, EPA (2002) presents methods to calculate a mechanical-driven particulate emission factor $\left(\mathrm{PEF}_{\mathrm{m}}\right)$, dermal assessment methods are presented in EPA (2004), and an "inhalation expression" is presented in EPA (2000b). A region-specific PEF $\mathrm{m}_{\mathrm{m}}$ is typically used in conjunction with the site-specific outdoor construction worker. This EPA scenario assumes site activity with heavy equipment to be actively resuspending soil. The 2007 screening estimates presented in this document do not include the construction worker due to the highly variable and site-specific inputs required to appropriately calculate $\mathrm{PEF}_{\mathrm{m}}$. It is highly recommended that incorporation of the $\mathrm{PEF}_{\mathrm{m}}$ be considered for contaminated sites with large areas requiring an anticipated lengthy period of remediation.

The current EPA indoor worker model omits the dermal pathway. However, it is plausible that an indoor worksite may be downwind from a heavy construction area, and contaminated dust may infiltrate the indoor worksite. In the event of dust infiltration, the dermal route should be applied to the indoor worker screening equation. Further, the indoor worker activities may more closely resemble residential activity patterns rather than those of an outdoor worker. Sensitivity analysis for the vesicant agent $L$ results in an increase in the worker screening level estimate by two orders of magnitude (to $204 \mathrm{mg} \mathrm{L} / \mathrm{kg}$ soil for indoor worker) when compared to the 1999 HBESL estimate [which incorporated dermal absorption to derive the (outdoor) worker HBESL estimate of $3.7 \mathrm{mg}$ $\mathrm{L} / \mathrm{kg}$ soil]. By employing the 2007 EPA protocol (of no dermal component), indoor worker skin exposure to soil at the estimated HBESL of $204 \mathrm{mg} \mathrm{L} / \mathrm{kg}$ soil poses an increased risk of vesicant skin damage. As a consequence, the present assessment added consideration of the dermal route to the indoor worker evaluation by inclusion of the residential dermal exposure parameters.

The "inhalation expression" divides the time a receptor spends outdoors from that spent indoors and applies an indoor air dilution factor to the time spent indoors. Though use of the inhalation expression is currently not employed in EPA chemical PRGs, it is understood that the "inhalation expression" is a scientifically defensible and plausible assessment tool that may be warranted for certain site-specific scenarios. This 2007 evaluation follows current EPA chemical PRG protocol and final values thus do not incorporate the inhalation expression. However, and for completeness, this evaluation has quantified incorporation of the "inhalation expression" to evaluate its potential impact on screening level estimates. The resulting screening value estimates were less protective and are thus not presented as default screening levels in this evaluation.

Screening values such as HBESLs may be used to assess soil or other porous media to determine whether CWA contamination is present as part of initial site investigations (whether due to intentional or accidental releases), and to determine whether weather/decontamination has adequately mitigated the presence of CWA residual to below levels of concern. However, despite the availability of scientifically supported health-based criteria, significant resources are involved that should be considered during sample planning. In particular, few analytical laboratories are likely to be able to meet these screening levels. Analyses will take time and usually have limited confidence at these concentrations. Therefore, and particularly for the more volatile agents, soil/destructive samples of 
porous media should be limited and instead enhanced with headspace monitoring and presenceabsence wipe sampling.

Samples taken for CWA analyses and comparison to HBESLs should also include analyses for the key associated breakdown products as described in Table ES.2. 



\begin{abstract}
This report evaluates whether new information and updated scientific models require that changes be made to previously published health-based environmental soil screening levels (HBESLs) and associated environmental fate/breakdown information for chemical warfare agents (USACHPPM 1999). Specifically, the present evaluation describes and compares changes that have been made since 1999 to U.S. Environmental Protection Agency (EPA) risk assessment models, EPA exposure assumptions, as well as to specific chemical warfare agent parameters (e.g., toxicity values). Comparison was made between screening value estimates recalculated with current assumptions and earlier health-based environmental screening levels presented in 1999.

The chemical warfare agents evaluated include the G-series and VX nerve agents and the vesicants sulfur mustard (agent HD) and Lewisite (agent L). In addition, key degradation products of these agents were also evaluated.

Study findings indicate that the combined effect of updates and/or changes to EPA risk models, EPA default exposure parameters, and certain chemical warfare agent toxicity criteria does not result in significant alteration to the USACHPPM (1999) health-based environmental screening level estimates for the G-series and VX nerve agents or the vesicant agents HD and L. Given that EPA's final position on separate Tier 1 screening levels for indoor and outdoor worker screening assessments has not yet been released as of May 2007, the study authors find that the 1999 screening level estimates (see Table ES.1) are still appropriate and protective for screening residential as well as nonresidential sites. As such, risk management decisions made on the basis of USACHPPM (1999) recommendations do not require reconsideration. While the 1999 HBESL values are appropriate for continued use as general screening criteria, the updated "2007" estimates (presented below) that follow the new EPA protocols currently under development are also protective. When EPA finalizes and documents a position on the matter of indoor and outdoor worker screening assessments, site-specific risk assessments should make use of modified models and criteria.
\end{abstract}

Screening values such as those presented in this report may be used to assess soil or other porous media to determine whether chemical warfare agent contamination is present as part of initial site investigations (whether due to intentional or accidental releases) and to determine whether weather/decontamination has adequately mitigated the presence of agent residual to below levels of concern. However, despite the availability of scientifically supported health-based criteria, there are significant resources needs that should be considered during sample planning. In particular, few analytical laboratories are likely to be able to meet these screening levels. Analyses will take time and usually have limited confidence at these concentrations. Therefore, and particularly for the more volatile agents, soil/destructive samples of porous media should be limited and instead enhanced with headspace monitoring and presence-absence wipe sampling. 



\section{INTRODUCTION}

\subsection{PURPOSE}

The purpose of this report is to determine whether new information and updated scientific models require that changes be made to previously published health-based environmental screening levels (HBESLs) and associated environmental fate/breakdown information for chemical warfare agents (CWA). The HBESLs for sulfur mustard (HD), Lewisite (L), Tabun (GA), Sarin (GB), Soman (GD) and VX were documented in the USACHPPM's 1999 report Derivation of Health-Based Environmental Screening Levels for Chemical Warfare Agents (USACHPPM 1999). The USACHPPM (1999) report was endorsed by the Headquarters of the Department of the Army as the current state of science and Army standard practice for investigation and assessment of environmental media potentially contaminated with CWA (HQDA 1999).

This document describes changes made since 1999 to U.S. Environmental Protection Agency (EPA) risk assessment models, EPA exposure assumptions, and specific chemical warfare agent (CWA) input parameters (e.g., toxicity values) and recalculates HBESL estimates accordingly. This report also presents current information about agent persistence, key CWA breakdown products, and HBESL applications. All estimates are presented to two significant figures.

\subsection{BACKGROUND}

USACHPPM (1999) evaluated available CWA data as well as EPA Region III risk-based concentrations (RBCs), EPA Region IX preliminary remediation goals (PRGs) and EPA Office of Solid Waste and Emergency Response (OSWER) soil screening levels (SSLs). HBESLs were presented for residential and industrial land use scenarios for each of the three EPA organizations identified above. Appendix A presents the USACHPPM (1999) HBESL values for reference.

In addition to the calculated HBESLs, key findings presented in the 1999 USACHPPM report included summary of chronic CWA toxicity values, other chemical and physical properties, an appraisal of potential groundwater contamination by CWAs, principal agent degradation products of interest during environmental investigations and their chronic toxicity values, and consideration of alternate exposure scenarios (e.g., trespasser, agricultural/grazing, etc.).

Since 1999, some of the underlying CWA toxicity values used in the calculations have undergone additional evaluation, and some changes have resulted. In particular, new general population limits (GPLs) were promulgated by the U.S. Department of Health and Human Services (DHHS), Centers for Disease Control and Prevention (CDC) in 2003 and 2004. In addition, the cancer SF and unit risk values for sulfur mustard agent have undergone additional evaluation (USACHPPM 2000a, 2004).

Furthermore, changes to the EPA risk models have occurred. Within the EPA Office of Superfund (Science and Policy Branch, Assessment and Remediation Division) preliminary remediation goals (PRGs) are presented and developed for both chemicals and radionuclides. In the majority of cases, PRG equations agree on use of the latest risk assessment guidance such as Risk Assessment Guidance for Superfund (RAGS) Parts A through E and Supplemental Soil Screening Levels (SSLs). However, differences do exist in equations for the inhalation exposure route between the chemical and radionuclide PRGs in the use of what is dubbed the "inhalation expression" for residents and indoor workers. The "inhalation expression" divides the time a receptor spends outdoors from that spent indoors, and applies an indoor air dilution factor to the time spent indoors. Though use of the inhalation expression is currently not employed in EPA chemical PRGs, it is understood that the 
"inhalation expression" is a scientifically defensible and plausible assessment tool that may be warranted for certain site-specific scenarios. This 2007 evaluation follows current EPA chemical PRG protocol, and final values thus do not incorporate the inhalation expression. However, and for completeness, this evaluation has quantified incorporation of the "inhalation expression" to evaluate its potential impact on screening level estimates. The resulting screening value estimates were less protective and are thus not presented as default screening levels in this evaluation. Widely published radionuclide PRGs incorporating the "inhalation expression" are readily found on the Internet at the following sites:

http://epa-prgs.ornl.gov/radionuclides/

http://epa-dccs.ornl.gov/

http://rais.ornl.gov/rad_start.shtml.

Because of EPA regional differences, Superfund has established a National Screening Table Working Group for chemical PRGs and is working to find consensus between Regions III, VI, and IX PRG tables and the remaining EPA regions. The PRG websites for EPA Regions III, VI, and IX are

http://www.epa.gov/reg3hwmd/risk/human/index.htm http://www.epa.gov/earth1r6/6pd/rcra_c/pd-n/screen.htm http://www.epa.gov/region09/waste/sfund/prg/index.html.

Release of the Superfund National Screening Table website is anticipated in 2007. A website with a working calculator of the new PRG models is the Risk Assessment Information System (RAIS 2007; http://rais.ornl.gov/prg/prg_document.shtml). Not only does the RAIS provide its own calculation of PRGs, the RAIS provides links to all the websites mentioned. Further, the RAIS (2007) provides PRG equations for agriculture and recreational/trespasser scenarios, which are also discussed in this current screening level evaluation.

\subsection{SCOPE}

This updated analysis of health-based environmental screening levels includes reconsideration of previous assumptions and the rationale used to justify any changes. Recalculated values were then compared with the previously published (USACHPPM 1999) HBESLs that were developed using the Region IX PRG methodology. EPA guidance released since USACHPPM (1999) presents the evaluation of two industrial worker scenarios [indoor worker plus outdoor worker; in contrast to previous EPA guidance that addressed only one industrial (outdoor worker) scenario] as well as a modified residential model. Evaluation of an outdoor construction worker is optional and sitespecific. Current EPA guidance also provides new default exposure parameters for the worker scenarios and updated toxicity values incorporated into the equations.

Widely published PRG models incorporating the separate worker scenarios as developed by EPA (2004) are readily found on the Internet at the following sites:

http://epa-prgs.ornl.gov/radionuclides/

http://epa-dccs.ornl.gov/

http://www.epa.gov/earth1r6/6pd/rcra_c/pd-n/screen.htm

http://rais.ornl.gov/index.shtml

http://rais.ornl.gov/rad_start.shtml.

Points of contact are provided on the individual websites. 
It is assumed that soil sampling will be accompanied with air monitoring. Air samples should be compared with established air criteria (see Table 1). Other sampling performed may include surface (wipe) criteria for which there are presently no established risk assessment models. Therefore, the current surface sampling decision criterion is to use "no detection" based on an analytical extraction and analyses with GC/MS technology. As for drinking water, USACHPPM (1999) evaluated the potential for ground water contamination from CWA and determined the scenario was not plausible. In addition, the long-term contamination of large bodies of water with CWA for an extended period of time was also considered implausible due to agent hydrolysis, degradation, and dilution. Therefore, it is recommended that evaluation of water be focused on the acute hazard (i.e., exposures lasting less than $7 \mathrm{~d}$ ). The military has established field drinking water criteria for these agents (DA 2005a, addressed in Appendix B).

Table 1. Comparison of 1999 to $2007 \mathrm{CW}$ toxicity values

\begin{tabular}{|c|c|c|c|c|c|c|c|c|}
\hline Agent & $\begin{array}{l}\text { 1999/2007 } \\
\text { Oral RfD } \\
(\mathrm{mg} / \mathrm{kg} / \mathrm{d})\end{array}$ & $\begin{array}{c}\text { 1999/2007 } \\
\text { Oral SF } \\
(\mathrm{mg} / \mathrm{kg} / \mathrm{d})^{-1}\end{array}$ & $\begin{array}{c}1999 \\
\text { Inhalation } \\
\text { SF } \\
(\mathrm{mg} / \mathrm{kg} / \mathrm{d})^{-1}\end{array}$ & $\begin{array}{c}2007 \\
\text { Inhalation } \\
\text { SF } \\
(\mathrm{mg} / \mathrm{kg} / \mathrm{d})^{-1}\end{array}$ & $\begin{array}{c}1999 \\
\text { General } \\
\text { public } \\
\text { air } \\
\text { exposure } \\
\text { limit } \\
\left(\mathrm{mg} / \mathrm{m}^{3}\right)^{b}\end{array}$ & $\begin{array}{c}1999 \\
\text { Inhalation } \\
\text { RfD }^{c} \\
(\mathbf{m g} / \mathbf{k g} / \mathbf{d})\end{array}$ & $\begin{array}{c}2003 \text { and } \\
2004 \\
\text { General } \\
\text { public } \\
\text { air exposure } \\
\text { limit } \\
\left(\mathrm{mg} / \mathrm{m}^{3}\right)^{d}\end{array}$ & $\begin{array}{c}2007 \\
\text { Inhalation } \\
\text { RfD }^{e} \\
(\mathrm{mg} / \mathrm{kg} / \mathrm{d})\end{array}$ \\
\hline HD & $7 \times 10^{-6}$ & $7.7^{f}$ & $300^{g}$ & $14.35^{h}$ & $1 \times 10^{-4}$ & $3 \times 10^{-5}$ & $2 \times 10^{-5}$ & $5.7 \times 10^{-6}$ \\
\hline $\mathrm{L}$ & $1 \times 10^{-4}$ & $\mathrm{NC}$ & $\mathrm{NC}$ & $\mathrm{NC}$ & $3 \times 10^{-3}$ & $8.6 \times 10^{-4}$ & $3 \times 10^{-3}$ & $8.6 \times 10^{-4}$ \\
\hline GA & $4 \times 10^{-5}$ & $\mathrm{NC}$ & $\mathrm{NC}$ & $\mathrm{NC}$ & $3 \times 10^{-6}$ & $9 \times 10^{-7}$ & $1 \times 10^{-6}$ & $2.9 \times 10^{-7}$ \\
\hline GB & $2 \times 10^{-5}$ & $\mathrm{NC}$ & $\mathrm{NC}$ & $\mathrm{NC}$ & $3 \times 10^{-6}$ & $9 \times 10^{-7}$ & $1 \times 10^{-6}$ & $2.9 \times 10^{-7}$ \\
\hline GD/GF & $4 \times 10^{-6}$ & $\mathrm{NC}$ & $\mathrm{NC}$ & $\mathrm{NC}$ & $1 \times 10^{-6}$ & $3 \times 10^{-7}$ & $1 \times 10^{-6}$ & $3 \times 10^{-7}$ \\
\hline VX & $6 \times 10^{-7}$ & $\mathrm{NC}$ & $\mathrm{NC}$ & $\mathrm{NC}$ & $3 \times 10^{-7^{i}}$ & $9 \times 10^{-8}$ & $6 \times 10^{-7}$ & $1.7 \times 10^{-7}$ \\
\hline
\end{tabular}

$\mathrm{NC}=$ No cancer SF available.

${ }^{a}$ OTSG 2000; Opresko et al. (2001). No change between 1999 and 2007.

${ }^{b}$ DHHS (1988); DA (1990, 1991).

${ }^{c}$ Estimated from the air exposure limits documented in DHHS 1988; DA 1990, 1991 using an inhalation rate of $20 \mathrm{~m}^{3} / \mathrm{d}$ and a body weight of $70 \mathrm{~kg}$.

${ }^{d}$ DHHS (2003, 2004); DA (2004); no change in air exposure limits for L or GD and GF.

${ }^{e}$ Estimated from the air exposure limits documented in DHHS $(2003,2004)$ using an inhalation rate of $20 \mathrm{~m}^{3} / \mathrm{d}$ and a body weight of $70 \mathrm{~kg}$ for conversion to an inhalation RfD.

${ }^{f}$ Geometric mean of estimated oral SFs; see USACHPPM (1999; Sect. 1.2.4) for derivation; recommended in OTSG (2000). ${ }^{g}$ DA (1996); derived from an inhalation unit risk of $8.5 \times 10^{-2}$ per $\mu \mathrm{g} \mathrm{HD} / \mathrm{m}^{3}$ [EPA 1991a; see EPA (1991b) for method]. ${ }^{h}$ From HD inhalation unit risk of $4.1 \times 10^{-3}$ per $\mu \mathrm{g} / \mathrm{m}^{3}$ (from USACHPPM 2000a) and associated inhalation SF of 14.35 per $\mathrm{mg} / \mathrm{kg} / \mathrm{d}$.

${ }^{i}$ In 1999, the CDC and Army-endorsed general population air limit for VX was $3 \times 10^{-6} \mathrm{mg} \mathrm{VX} / \mathrm{m}^{3}$. At the time of USACHPPM (1999) publication, CDC communications indicated that a potentially updated general population exposure limit for VX would be $3 \times 10^{-7} \mathrm{mg} \mathrm{VX} / \mathrm{m}^{3}$. Hence, the potential CDC value of $3 \times 10^{-7} \mathrm{mg} \mathrm{VX} / \mathrm{m}^{3}$ was used in the $1999 \mathrm{HBESL}$ assessment. The final value published by CDC in DHHS (2003) was $6 \times 10^{-7} \mathrm{mg} \mathrm{VX} / \mathrm{m}^{3}$. 



\section{CHANGES IN CHEMICAL-SPECIFIC VALUES}

\subsection{PHYSICAL PARAMETERS}

Appendix C (Table C.1) compares the physical, chemical, and environmental parameters used in USACHPPM (1999) with those used in this report. Minimal changes were made to update the agentspecific information summarized in 1999, primarily due to inclusion of recent compilations published since 1999 (DA 2005b; NRC 2003; Talmage et al. 2007a,b; Bartelt-Hunt et al. 2006). Chemical and physical properties for principal degradation products have also been included in Appendix C (see Table C.2).

\subsection{TOXICITY VALUES}

Several agent-specific toxicity values have been finalized and published since 1999, when toxicity value updates were in progress (see Table 1 for comparison). No oral reference doses (RfDs) changed, and the oral slope factor (SF) for HD is unchanged. Inhalation RfDs have been updated for all agents except Lewisite and the nerve agents GD/GF, which remain unchanged from USACHPPM (1999) (DHHS 2003, 2004). The inhalation SF for HD was updated with recent recommendations for inhalation unit risk (USACHPPM 2000a, NRC 2003).

Review of the oral slope factor analysis for agent HD included consideration of previous recommendations published by NRC (1999; oral SF of 1.6 per mg HD/kg/d) and USACHPPM (1999; geometric mean SF of 7.7 per $\mathrm{mg} \mathrm{HD} / \mathrm{kg} / \mathrm{d})$. Of these two oral SF estimates, the NRC-recommended SF for HD of 1.6 per $\mathrm{mg} / \mathrm{kg} / \mathrm{d}$ is a less conservative estimate and considers HD to be of lower carcinogenic potency than previous Army values or the USACHPPM (1999) value. Given obvious uncertainties and ongoing evaluation of alternative methods for estimating cancer SFs, the Army Office of the Surgeon General is currently recommending use of the sulfur mustard oral SF value of 7.7 per $\mathrm{mg} \mathrm{HD} / \mathrm{kg} / \mathrm{d}$ (OTSG 2000) as an appropriately protective estimate of the ingestion cancer potency of HD. Thus, the oral SF of 7.7 per $\mathrm{mg} / \mathrm{kg} / \mathrm{d}$ is retained in the current analysis.

Review of agent HD inhalation unit risk was performed in USACHPPM (2000a) and incorporated estimates and input from several investigators in the field. The resulting geometric mean inhalation unit risk of $4.1 \times 10^{-3}$ per $\mu \mathrm{g} \mathrm{HD} / \mathrm{m}^{3}$ was derived using contemporary accepted methods and is considered robust and reflective of the current body of knowledge on the carcinogenicity of airborne sulfur mustard agent (NRC 2003). Consequently, the inhalation unit risk estimate of $4.1 \times 10^{-3}$ per $\mu \mathrm{g} \mathrm{HD} / \mathrm{m}^{3}$ from USACHPPM (2000a) and the associated inhalation SF of $14.35 \mathrm{per} \mathrm{mg} \mathrm{HD} / \mathrm{kg} / \mathrm{d}$ are now substituted for the former values used to develop the 1999 HBESL values [e.g., inhalation unit risk of $8.5 \times 10^{-2}$ per $\mu \mathrm{g} \mathrm{HD} / \mathrm{m}^{3}$ from EPA (1991a) with the associated inhalation SF of 300 per $\mathrm{mg} \mathrm{HD} / \mathrm{kg} / \mathrm{d}]$.

Recent EPA toxicity profiles released by IRIS present inhalation reference concentrations (RfCs) and inhalation unit risks (IURs) rather than inhalation RfDs and inhalation SF, respectively (EPA 2005b). Also note that EPA programs are currently recommending the use of RfCs and IURs in their screening tables and guidance documents (EPA 2007). In this evaluation, the effect on the HBESL equations of using IURs or SFs is analyzed.

To convert from an IUR to a SF requires multiplication of the IUR (per $\mathrm{mg} / \mathrm{m}^{3}$ ) by the body weight (70-kg default) divided by the inhalation rate (20- $\mathrm{m}^{3} / \mathrm{d}$ default). To convert from a RfD to a RfC requires multiplication of the $\mathrm{RfD}(\mathrm{mg} / \mathrm{kg} / \mathrm{d})$ by the body weight $(\mathrm{kg})$ divided by the inhalation rate $\left(\mathrm{m}^{3} / \mathrm{d}\right)$. The net effect of using RfDs or SFs rather than RfCs or IURs is zero (because the model 
equations using RfCs or IURs do not contain body weight or inhalation rate) (EPA 1989; EPA 1991c).

Review of estimated reference doses for CWAs was published by the NRC Committee on Toxicology Subcommittee on Chronic Reference Doses for Selected Chemical Warfare Agents (NRC 1999) and finalized by the Office of the Army Surgeon General in 2000 (OTSG 2000; Opresko et al. 2001). General public air exposure limits under review by the Department of Health and Human Services in 1999 were finalized by publication in the Federal Register in 2003 (for nerve agents GA, GB, and VX; DHHS 2003) and 2004 (for sulfur mustard agent HD; DHHS 2004). The DHHS did not revisit values previously established in 1988 for the vesicant agent Lewisite or the nerve agents GD and GF; thus, values for these three agents remain unchanged since 1988 (DHHS 1988). The current GD and GF general public exposure limits of $1 \times 10^{-6} \mathrm{mg} / \mathrm{m}^{3}$ were confirmed by the Office of the Assistant Secretary of the Army (Installations and Environment) in 2004 (DA 2004). Accordingly, and with the exception of Lewisite and GD/GF, inhalation RfDs for all other agents have been revised for the 2007 estimates performed during the present analysis.

Dermal absorption values used for resident and workers are presented in Appendix D and are the same as those employed in USACHPPM (1999).

\subsection{AGENT PERSISTENCE}

With the exception of recent data published for VX persistence on concrete (Williams et al. 2005; Wagner et al. 2001), there has been little change regarding basic knowledge of agent persistence since USACHPPM (1999), which contains a good summary of main points. More recent summaries of agent persistence under various environmental conditions include Bartelt-Hunt et al. (2006) and Talmage et al. (2007a,b).

Hydrolysis remains an important fate and degradation pathway for all chemical warfare agents examined in this analysis. According to Bartelt-Hunt et al. (2006), mathematical modeling of CW agent fate (including the G-series nerve agents, nerve agent VX, and vesicant agents HD and L) under municipal landfill conditions indicates that many of the examined CWAs "were completely transformed by hydrolysis within 1 year," with rapid hydrolysis occurring in the first days and weeks after simulated release.

Chemical and physical properties of the CW agents and principal degradation products are summarized in Appendix C.

\section{$\underline{\text { Sulfur mustard }}$}

Agent HD is considered an environmentally persistent CWA. Chemically, HD is a thioether; its physical state at ambient temperatures is an oily liquid. The vapor pressure is low, $0.11 \mathrm{~mm} \mathrm{Hg}$ at $25^{\circ} \mathrm{C}$ (Samuel et al. 1983), but sufficient for mustard to be in the air immediately surrounding droplets of the liquid. The primary dissipation mechanism for HD from soil is evaporation. Sulfur mustard vapor is 5.5 times heavier than air, and evaporation or volatilization from surfaces or soils is projected to require days at temperatures above its freezing point of $13-14^{\circ} \mathrm{C}$ (DA 2005b). Below its freezing temperature, HD is a solid, and evaporation as well as hydrolysis is slower. Small (1984), in reviewing experimental studies available at the time, estimated that HD maintains a vapor hazard for several hours to several weeks after initial contamination of soil. HD may persist in soil or under undisturbed water for longer periods of time. 
Once dissolved, HD undergoes rapid hydrolysis (Bartlett and Swain 1949). However, the overall process of hydrolytic destruction is limited by the very low water solubility of HD.

\section{Lewisite}

In water or aqueous solutions, Lewisite is considered nonpersistent due to its very rapid hydrolysis ("immediate" or "instantaneous," DA 2005b; Buswell et al. 1944) to Lewisite oxide (2-chlorovinyl arsenious oxide, $\mathrm{C}_{2} \mathrm{H}_{2} \mathrm{AsClO}$ ), which is a solid. Lewisite oxide is slow to dissolve in water and is thus considered more persistent than Lewisite. Lewisite oxide retains the trivalent arsenic (of L).

\section{$\underline{\text { Nerve agent VX }}$}

Under normal environmental conditions, VX is relatively resistant to hydrolysis (Franke 1982). VX hydrolysis in the environment is dependent on environmental $\mathrm{pH}$, and the hydrolysis rate increases as the $\mathrm{pH}$ increases (Epstein 1974). With a limited source of moisture, reactions in the environment occur slowly, as dissolved VX forms an acid solution.

VX can be hydrolyzed by two pathways (see Munro et al. 1999). In both acid and alkaline conditions, cleavage of the P-S bond predominates. In a solution of $0.01 \mathrm{M}$ VX and aqueous $0.1 \mathrm{M} \mathrm{NaOH}, \mathrm{VX}$ was hydrolyzed to ethyl methylphosphonic acid (EMPA, $\mathrm{C}_{3} \mathrm{H}_{9} \mathrm{PO}_{3}$ ) and $O$-ethyl-S-

(2-diisopropylaminoethyl) methylphosphonothioate (EA 2192, $\mathrm{C}_{9} \mathrm{H}_{22} \mathrm{NSPO}_{2}$ ) ions in a ratio of $87 \%$ to $13 \%$, respectively. Under these conditions, the half-life of VX was $31 \mathrm{~min}$ (Szafraniec et al. 1990; Yang et al. 1993).

In a recent experimental study, trace amounts of VX on concrete surfaces (a neutral to alkaline surface) degraded with a half-life of 2-3 h at room temperature. Degradation was by cleavage of the P-S and S-C bonds, with the major degradation product being diisopropylaminoethyl mercaptoamine (DESH; Williams et al. 2005). This result is consistent with alkaline hydrolysis within water films associated with the concrete surface.

When VX droplets are applied to (aged) concrete chunks, two-step kinetics are exhibited (Wagner et al. 2001). An initial hydrolysis reaction with an approximate 2-h half-time consumed $12 \%$ of the applied VX, while a second hydrolysis reaction with a 28-d half-time followed. Only DESH and ethyl methyphosphonic acid (EMPA) were detected during both phases of hydrolysis; no "parent" VX or toxic EA 2192 were ever observed during the entire period of study (Wagner et al. 2001).

\section{$\underline{\text { Nerve agent GA }}$}

Agent GA present in the environment is subject to evaporation and hydrolysis. The vapor pressure is $0.07 \mathrm{~mm} \mathrm{Hg}$ at $25^{\circ} \mathrm{C}$, making agent GA more volatile than VX. GA rapidly dissolves in water. Hydrolysis is more rapid under acidic and basic solutions than at neutral $\mathrm{pH}$. Even under acidic and basic conditions, laboratory studies show that GA would persist with a half-life of hours (summarized in Munro et al. 1999). Persistence in the environment may be even longer under certain weather conditions such as extreme cold.

\section{$\underline{\text { Nerve agent GB }}$}

GB is considered nonpersistent in the environment as it is volatile, soluble in water, and subject to acidic and basic hydrolysis. The evaporation rate of GB approximates that of water (Rosenblatt et al. 1995). Hydrolysis rates are dependent on temperature, $\mathrm{pH}$, and water quality, and estimated half-lives under ambient conditions are in the range of several days (Munro et al. 1999). 
The persistence of GB on surfaces has been studied. At $25^{\circ} \mathrm{C}$ and a loading of $3.33 \mathrm{mg} / \mathrm{m}^{2}$, GB persisted on concrete for only $2 \mathrm{~h}$ (Cooper 1990). GB essentially disappeared from pulverized or intact concrete in $\leq 30$ min (Carpenter and Hill 1988).

\section{$\underline{\text { Nerve agent GD }}$}

GD is more persistent than GB. The vapor pressure of $0.40 \mathrm{~mm} \mathrm{Hg}$ at $25^{\circ} \mathrm{C}$ (Samuel et al. 1983) is lower than that of GB (but higher than that of GA), and volatilization is expected to take several hours (Small 1984). GD evaporates at about one-fourth the rate of water (Rosenblatt et al. 1995).

Under field conditions, the measured decay of GD is rapid (McGuire et al. 1993). The Chemical and Biological Defense Establishment at Porton Down (UK) conducted outdoor experiments in which GD was deposited on $1-\mathrm{m}^{2}$ plots of soil at an areal concentration of $10 \mathrm{~g} / \mathrm{m}^{2}$ (McGuire et al. 1993).

Samples were collected immediately (Day 0) and during the following $3 \mathrm{~d}$. The initial decomposition was from hydrolysis of the P-F bond as evidenced in the Day 0 samples. The phosphonate partial ester and MPA peaked in the Day 1 samples and declined subsequently.

Short-term field trials have been performed with GD droplets applied to silica sand at $5.21 \mathrm{~g} / \mathrm{m}^{2}$, and laboratory experiments have been conducted with GD liquid applied to soil (USAF 2003; Murdock et al. 2004). These studies have demonstrated potential for GD off-gassing due to volume displacement following actual and simulated rain events within hours after initial agent application. With repeated and simulated rain events, GD, via off-gassing from soil, declined to nondetectable concentrations at 73.3-h postapplication (following five simulated rain events).

\subsection{AGENT DEGRADATION PRODUCTS}

Samples taken for CWA analyses and comparison to HBESLs should also include analyses for the key associated breakdown products as identified and characterized below.

Agent degradation reactions and conditions are largely unchanged from those summarized in USACHPPM (1999). Additional details of agent degradation reactions and products can be found in Talmage et al. (2007a,b), Munro et al. (1999), and Bartelt-Hunt et al. (2006), and are briefly described below.

Agent degradation products that are considered relatively persistent in the environment and/or potentially toxic are summarized in Table 2, which has been updated from that presented in USACHPPM (1999) by information from recent publications estimating a reference dose for thiodiglycol (Reddy et al. 2005) and inclusion of degradation product persistence and pertinent chemical and physical properties.

\section{Sulfur mustard}

Once dissolved, HD undergoes rapid hydrolysis (Bartlett and Swain 1949). However, the overall process of hydrolytic destruction is limited by the very low water solubility of HD. In the presence of insufficient water to initially dissolve all available $\mathrm{HD}$, several sulfonium ion aggregates are formed at the water-HD interface. These aggregates hinder HD transport into solution and retard hydrolysis. Thus, bulk-released amounts of HD can undergo "encapsulation" within an inert polymeric coating formed by HD hydrolysis products (Rosenblatt 1995). The presence of encapsulated HD in soil has been associated in the field with continuous sources of sulfur mustard, that is, with buried, leaking, bulk containers. 
Table 2. Principal chemical warfare agent degradation products of concern, with associated chronic toxicity guidelines ${ }^{a}$

\begin{tabular}{|c|c|c|c|c|}
\hline $\begin{array}{l}\text { Agent/synonyms } \\
\text { (CAS No.) }\end{array}$ & $\begin{array}{l}\text { Degradation } \\
\text { process }\end{array}$ & $\begin{array}{c}\text { Degradation product or impurity } \\
\text { (CAS No. })^{a}\end{array}$ & $\begin{array}{c}\text { Persistence and notable chemical-physical } \\
\text { properties }{ }^{b}\end{array}$ & $\begin{array}{l}\text { Chronic toxicity values of } \\
\text { degradation products }^{c}\end{array}$ \\
\hline $\begin{array}{l}\text { Sulfur mustard (H, HD) } \\
(505-60-2)\end{array}$ & Hydrolysis & $\begin{array}{c}\text { Thiodiglycol } \\
(111-48-8)\end{array}$ & $\begin{array}{l}\text { Moderate } \\
\text { Nonvolatile, miscible with water } \\
\text { Resistant to hydrolysis, biodegradable }\end{array}$ & $\begin{array}{l}\text { est. RfD: } 4.0 \times 10^{-1} \mathrm{mg} / \mathrm{kg} / \mathrm{d}^{d} \\
\text { est. RfC: } 4.67 \times 10^{-1} \mathrm{mg} / \mathrm{m}^{3}\end{array}$ \\
\hline $\begin{array}{l}\text { Dichloro-(2-chlorovinyl)arsine; Lewisite } \\
(541-25-3)\end{array}$ & $\begin{array}{l}\text { Hydrolysis, } \\
\text { dehydration }\end{array}$ & $\begin{array}{l}\text { Lewisite oxide }^{e} \\
(3088-37-7)\end{array}$ & $\begin{array}{l}\text { High } \\
\text { Water insoluble } \\
\text { Potential oxidation in soil }\end{array}$ & $\begin{array}{l}\text { est. RfD: } 1.0 \times 10^{-4} \mathrm{mg} / \mathrm{kg} / \mathrm{d} \\
\text { est. RfC: } 1.1 \times 10^{-4} \mathrm{mg} / \mathrm{m}^{3}\end{array}$ \\
\hline $\begin{array}{l}O \text {-Ethyl- } S \text {-[2-diisopropylaminoethyl] } \\
\text { methylphosphonothioate; VX } \\
(50782-69-9)\end{array}$ & Hydrolysis & $\begin{array}{l}\text { EA } 2192^{f} \\
(73207-98-4) \\
\text { Ethyl methylphosphonic acid; EMPA } \\
(1832-53-7) \\
\\
\text { Methyl phosphonic acid; MPA } \\
(993-13-5)\end{array}$ & $\begin{array}{l}\text { Moderate } \\
\text { Low volatility } \\
\text { High water solubility } \\
\text { Resistant to hydrolysis } \\
\text { Moderate } \\
\text { Low volatility } \\
\text { Water soluble } \\
\text { Resistant to hydrolysis } \\
\text { Biodegradable } \\
\text { High } \\
\text { Low volatility } \\
\text { Resistant to photolysis } \\
\text { Resistant to hydrolysis } \\
\text { High water solubility } \\
\text { Mobile in soils } \\
\text { Resistant to biodegradation }\end{array}$ & $\begin{array}{l}\text { est. RfD: } 6.0 \times 10^{-7} \mathrm{mg} / \mathrm{kg} / \mathrm{d} \\
\text { est. RfC: } 7.0 \times 10^{-7} \mathrm{mg} / \mathrm{m}^{3} \\
\text { est. RfD: } 2.8 \times 10^{-2} \mathrm{mg} / \mathrm{kg} / \mathrm{d} \\
\text { est. RfC: } 3.4 \times 10^{-2} \mathrm{mg} / \mathrm{m}^{3} \\
\\
\text { est. RfD: } 2.0 \times 10^{-2} \mathrm{mg} / \mathrm{kg} / \mathrm{d}^{h} \\
\text { est. RfC: } 2.4 \times 10^{-2} \mathrm{mg} / \mathrm{m}^{3}\end{array}$ \\
\hline $\begin{array}{l}\text { GA; Tabun; Ethyl } \\
N, N \text {-dimethylphosphoramidocyanidate } \\
(77-81-6)\end{array}$ & Hydrolysis & None of potential concern & NA & NA \\
\hline $\begin{array}{l}\text { GB; Sarin; Isopropyl } \\
\text { methylphosphonofluoridate (107-44-8) }\end{array}$ & Hydrolysis & $\begin{array}{l}\text { Isopropyl methylphosphonic acid; } \\
\text { IMPA } \\
\text { (1832-54-8) } \\
\text { Methyl phosphonic acid; MPA } \\
(993-13-5)\end{array}$ & $\begin{array}{l}\text { High } \\
\text { Low vapor pressure } \\
\text { Water soluble } \\
\text { Resistant to hydrolysis } \\
\text { Resistant to biodegradation } \\
\text { High } \\
\text { Low volatility } \\
\text { Resistant to photolysis } \\
\text { Resistant to hydrolysis } \\
\text { High water solubility } \\
\text { Mobile in soils } \\
\text { Resistant to biodegradation }\end{array}$ & $\begin{array}{l}\text { est. RfD: } 1.0 \times 10^{-1} \mathrm{mg} / \mathrm{kg} / \mathrm{d} \\
\text { est. RfC: } 1.1 \times 10^{-1} \mathrm{mg} / \mathrm{m}^{3} \\
\text { est. RfD: } 2.0 \times 10^{-2} \mathrm{mg} / \mathrm{kg} / \mathrm{d}^{h} \\
\text { est. RfC: } 2.4 \times 10^{-2} \mathrm{mg} / \mathrm{m}^{3}\end{array}$ \\
\hline
\end{tabular}


Table 2. (continued)

\begin{tabular}{|c|c|c|c|c|}
\hline $\begin{array}{c}\text { Agent/Synonyms }{ }^{a} \\
\text { (CAS No.) }\end{array}$ & $\begin{array}{l}\text { Degradation } \\
\text { process }\end{array}$ & $\begin{array}{l}\text { Degradation product or impurity } \\
\text { (CAS No.) }\end{array}$ & $\begin{array}{c}\text { Persistence and notable chemical-physical } \\
\text { properties }^{b}\end{array}$ & $\begin{array}{l}\text { Chronic toxicity values of } \\
\text { degradation products }\end{array}$ \\
\hline $\begin{array}{l}\text { GD; Soman; Pinacolyl } \\
\text { methylphosphonofluoridate } \\
(96-64-0)\end{array}$ & Hydrolysis & $\begin{array}{l}\text { Methyl phosphonic acid; MPA } \\
\text { (993-13-5) }\end{array}$ & $\begin{array}{l}\text { High } \\
\text { Low volatility } \\
\text { Resistant to photolysis } \\
\text { Resistant to hydrolysis } \\
\text { High water solubility } \\
\text { Mobile in soils } \\
\text { Resistant to biodegradation }\end{array}$ & $\begin{array}{l}\text { est. RfD: } 2.0 \times 10^{-2} \mathrm{mg} / \mathrm{kg} / \mathrm{d}^{h} \\
\text { est. RfC: } 2.4 \times 10^{-2} \mathrm{mg} / \mathrm{m}^{3}\end{array}$ \\
\hline
\end{tabular}

${ }^{a}$ Primary degradation products presented were selected on the basis of environmental persistence and/or toxicity. Production and yield of each product is dependent on site-specific chemical and physical parameters present both at the time, and throughout the duration, of agent release (e.g., temperature, $\mathrm{pH}$, etc.). Known chemical and physical properties of these degradation products are summarized in Table C.2, Appendix C; see Table C.2 for water and soil persistence of parent CW compounds.

${ }^{b}$ Persistence depends on environmental conditions; in general, moderate persistence indicates weeks to months, and high persistence indicates months to years.

cEstimated by Bausum et al. (1999), unless otherwise noted. "est. RfD” is an estimated Reference Dose; "est. RfC" is an estimated Reference Concentration. RfC estimate derived by assuming inhalation rate of $20 \mathrm{~m}^{3} / \mathrm{d}$, body weight of $70 \mathrm{~kg}$, and extrapolation UF of 3 (method of USACHPPM 1999, Appendix F).

${ }^{d}$ Reddy et al. (2005) for RfD estimate; RfC estimate derived by assuming inhalation rate of $20 \mathrm{~m}^{3} / \mathrm{d}$, body weight of $70 \mathrm{~kg}$, and extrapolation UF of 3 (method of USACHPPM 1999, Appendix F).

${ }^{e}$ Under continually moist conditions, the hydrolysis product 2-chlorovinyl arsonous acid (CVA; CAS \# 85090-33-1), a probable vesicant, may also be present. When Lewisite oxide or 2-chlorovinyl arsonous acid is known to be present in the environmental medium of concern, application of the estimated RfD for Lewisite is recommended (Opresko et al.

2001). Otherwise, the RfD for inorganic arsenic $\left(3.0 \times 10^{-4} \mathrm{mg} / \mathrm{kg} / \mathrm{d}\right)$ may be applied (U.S. EPA 2005a; because Lewisite in environmental media is eventually degraded to inorganic arsenic).

Retains the toxic mechanism of action of the parent CW agent, but is less toxic by approximately 6× (oral exposure; Michel et al. 1962). EA 2192 is a solid and poses no inhalation risk.

${ }^{g}$ Disappearance from soil may be due to a combination of hydrolysis and biodegradation.

${ }^{h}$ Quantitative structure-activity relationship estimate (USACHPPM 1999).

$\mathrm{NA}=$ Not available 
The overall hydrolysis reaction of HD yields thiodiglycol, which is practically nontoxic (Munro et al. 1999).

\section{$\underline{\text { Lewisite }}$}

Lewisite exhibits very low volatility. Based on its ultraviolet (UV) absorption band (Rewick et al. 1986), some photodegradation may take place in the atmosphere. Hydrolysis may also occur in the gas phase (MacNaughton and Brewer 1994).

According to Rosenblatt et al. (1975), solubility data for Lewisite are meaningless due to rapid hydrolysis resulting in formation of the water-soluble dihydroxy arsine or 2-chlorovinyl arsonous acid. Lewisite in solution quickly becomes essentially 100\% 2-chlorovinyl arsonous acid (Major 1998).

With the removal of water, 2-chlorovinyl arsonous acid forms Lewisite oxide (2-chlorovinyl arsenious oxide), a solid. Formation of Lewisite oxide and polymerized Lewisite oxide is essentially a dehydration reaction. Once formed, Lewisite oxide and polymerized Lewisite oxide are relatively insoluble in water. Once dry, the oxide will probably not readily redissolve or form the acid in the environment.

Lewisite is easily hydrolyzed by soil moisture, and minerals present in the soil would speed the process (Cooper 1990). Alkaline soils would neutralize Lewisite. Depending on environmental conditions, various inorganic arsenic compounds can be formed in the course of complete Lewisite mineralization. It is noted that inorganic arsenic compounds are found in areas of past Lewisite releases, although the limited quantity of Lewisite present in the United States would suggest limited areas of risk. Even if Lewisite were completely degraded, the toxic element arsenic (combined with metals or as salts) would remain.

As an ingestion exposure guideline, the estimated RfD for Lewisite $\left(1 \times 10^{-4} \mathrm{mg} / \mathrm{kg} / \mathrm{d}\right)$ is appropriate when Lewisite, 2-chlorovinyl arsonous acid, or Lewisite oxide is known to be present in the environmental medium of concern (Opresko et al. 2001). Otherwise, the RfD for inorganic arsenic $\left(3.0 \times 10^{-4} \mathrm{mg} / \mathrm{kg} / \mathrm{d}\right)$ may be applied (U.S. EPA 2005a) because Lewisite in environmental media is eventually degraded to inorganic arsenic.

Table 3 summarizes the calculated inorganic arsenic values for scenarios and equations described in this report. Arsenic is presented below as a detailed example of the screening level analyses performed for each of the CW agent degradation products identified in Table 2; results of this screening level evaluation are summarized in Table ES.2 and Sect. 5.

\section{Nerve agents}

The nerve agents are alkylphosphonic acid esters in which the phosphorus is bonded to a hydrocarbon group. This C-P bond is resistant to hydrolysis. V-agents such as VX contain a sulfur atom; GA contains a cyanide group; while GB and GD each contain a fluorine substituent group. Although the C-P bond is resistant to hydrolysis, the CN-P and F-P bonds of the G-agents are readily hydrolyzed.

When relatively pure, the nerve agents are viscous, clear liquids. Agent VX is the least volatile (vapor pressure $0.0007 \mathrm{~mm} \mathrm{Hg}$ at $20^{\circ} \mathrm{C}$ ), while $\mathrm{GB}$ (vapor pressure $2.10 \mathrm{~mm} \mathrm{Hg}$ at $20^{\circ} \mathrm{C}$ ) is the most volatile of these standard threat nerve agents (Munro et al. 1999 and others). The primary mode of nerve agent degradation in the environment is by rapid hydrolysis to the corresponding alkyl 
Table 3. Proposed arsenic soil screening level estimates for cancer and noncancer following EPA's chemical PRG model ${ }^{a}$

\begin{tabular}{|l|c|c|c|}
\hline \multicolumn{1}{|c|}{$\begin{array}{c}\text { Arsenic } \\
\text { estimate }\end{array}$} & $\begin{array}{c}\text { 2007 Age- } \\
\text { adjusted } \\
\text { resident }\end{array}$ & $\begin{array}{c}\text { 2007 Outdoor } \\
\text { worker }\end{array}$ & $\begin{array}{c}\text { 2007 Indoor } \\
\text { worker }\end{array}$ \\
\hline \multicolumn{3}{|c|}{ Cancer } \\
\hline HBESL & $3.9(\mathrm{mg} / \mathrm{kg})$ & $180(\mathrm{mg} / \mathrm{kg})$ & $380(\mathrm{mg} / \mathrm{kg})$ \\
\hline $\begin{array}{c}\text { Region VI } \\
\text { values }\end{array}$ & $3.9(\mathrm{mg} / \mathrm{kg})$ & $180(\mathrm{mg} / \mathrm{kg})$ & $380(\mathrm{mg} / \mathrm{kg})$ \\
\hline
\end{tabular}

\begin{tabular}{|l|c|c|c|c|}
\hline \multicolumn{5}{|c|}{ Noncancer } \\
\hline & $\begin{array}{c}\mathbf{2 0 0 7} \text { Child } \\
\text { resident }\end{array}$ & $\begin{array}{c}\mathbf{2 0 0 7} \text { Adult } \\
\text { resident }\end{array}$ & $\begin{array}{c}\mathbf{2 0 0 7} \text { Outdoor } \\
\text { worker }\end{array}$ & $\begin{array}{c}\text { 2007 Indoor } \\
\text { worker }\end{array}$ \\
\hline HBESL & $22(\mathrm{mg} / \mathrm{kg})$ & $47.0(\mathrm{mg} / \mathrm{kg})$ & $280(\mathrm{mg} / \mathrm{kg})$ & $610(\mathrm{mg} / \mathrm{kg})$ \\
\hline $\begin{array}{c}\text { Region VI } \\
\text { values }\end{array}$ & $22(\mathrm{mg} / \mathrm{kg})$ & NP & $280(\mathrm{mg} / \mathrm{kg})$ & $610(\mathrm{mg} / \mathrm{kg})$ \\
\hline
\end{tabular}

${ }^{a}$ Estimates assume $100 \%$ GI absorption of arsenic and are consistent with ATSDR (2005) and EPA (2004).

${ }^{b}$ Adjusted to match the target cancer risk of the HBESLs (e.g., $10^{-5}$ for residential and $10^{-4}$ for industrial workers).

$\mathrm{NP}=$ Not provided

methylphosphonates (Table 2). VX is hydrolyzed to ethyl methylphosphonic acid (EMPA), and more slowly to methyl phosphonic acid (MPA). GB degrades to isopropyl methylphosphonic acid, and GD is hydrolyzed to pinacolyl methylphosphonic acid. The hydrolytic degradation of GA is $\mathrm{pH}-$ dependent; at $\mathrm{pH}>7$, GA is hydrolyzed by hydroxide anion, producing ethyl dimethylphosphoramidate and cyanide anion as initial products. The initial hydrolysis products can be further hydrolyzed to finally give phosphoric acid. The same products are formed under neutral conditions. At $\mathrm{pH}<5$, GA hydrolyzes to produce ethylphosphoryl cyanidate and dimethylamine. 


\section{CHANGES TO EPA EXPOSURE PARAMETERS AND MODELS}

USACHPPM (1999) presented HBESLs for three EPA organizations that reflected regional and programmatic differences. Since 1999, maintenance of the EPA regional PRG tables has been infrequent, and all EPA regions are currently working with Superfund to fashion a national PRG table that is to supersede the EPA Office of Solid Waste and Emergency Response Soil Screening Levels (SSLs). Because of the EPA current desire for a "national" PRG table based on standardized equations, this report will present updated HBESLs based on current Superfund guidance. The "national" screening table approach is similar to the EPA Region IX PRG model and attempts to unify the risk model differences between EPA Regions III, VI, and IX. In 1999, the three regional tables contained differences in selection of toxicity values, inclusion of various chemicals, route-toroute extrapolation, and update frequency. It is the goal of the EPA's National Screening Table Working Group to resolve these differences and provide updates as new toxicity information becomes available.

This current evaluation of the CWA HBESLs follows the Superfund chemical PRG equations. This analysis also includes evaluation of previous exposure and PRG model assumptions and presentation of the rationale for changes. Recalculated values were then compared with the previously published (1999) HBESL estimates that had been developed using Region IX PRG methodology.

Since publication of USACHPPM (1999), changes have also occurred in the model equations for residential and industrial exposure derivations. Further, many of the default exposure parameters have also changed. EPA programs supporting the Risk Assessment Guidance for Superfund (RAGS): Volume I-Human Health Evaluation Manual (EPA 2004; Part E, Supplemental Guidance for Dermal Risk Assessment) and EPA (2002; Supplemental Guidance for Developing Soil Screening Levels for Superfund Sites) have released new models. In RAGS Part E, EPA (2004) has released new default exposure parameters, and EPA (2002) has divided the former industrial scenario into three separate worker scenarios: indoor worker, outdoor worker, and a site-specific outdoor construction worker. The resulting major changes in equations and exposure parameters are discussed in the following subsections.

\subsection{RESIDENTIAL EXPOSURE SCENARIO}

Prior to the recent EPA (2004) recommendations, soil-to-skin adherence factors of 0.08 and $0.3 \mathrm{mg} / \mathrm{cm}^{2}$ were used for resident adult and children, respectively, and appropriately incorporated into estimates presented in USACHPPM (1999). EPA (2004) now recommends use of 0.07 and $0.2 \mathrm{mg} / \mathrm{cm}^{2}$ for the adult and child, respectively.

Equations (1) and (2) of Appendix D, and the table of exposure parameters (Table D.1), evaluate the new equations and input parameters for residential exposure to soil. Of key interest is the following change:

- updated soil adherence factors [as presented in EPA (2004)].

\subsection{ADULT WORKER EXPOSURE SCENARIOS}

Prior to publication of the EPA (2004) recommendations, a soil-to-skin adherence factor of $0.08 \mathrm{mg} / \mathrm{cm}^{2}$ was used for all adults in USACHPPM (1999). EPA (2002) divides the traditional worker scenario into indoor and outdoor worker groups as well as a site-specific construction worker. This separation of worker scenarios has affected the ingestion, dermal, and inhalation route exposure 
estimates for each of the three scenarios. Ingestion rates of 50,100, and $330 \mathrm{mg} / \mathrm{d}$ are now used for the indoor, outdoor, and construction worker, respectively (EPA 2002). Further, EPA (2002) does not assess the dermal route for the indoor worker. For the outdoor worker and the construction worker, soil-to-skin adherence factors of 0.2 and $0.3 \mathrm{mg} / \mathrm{cm}^{2}$, respectively, are now used (EPA 2002). Exposure frequencies of 250 and $225 \mathrm{~d} /$ year are now used for the indoor and outdoor worker assessments, respectively. EPA now recommends that many of the exposure parameters for the construction worker (such as exposure frequency, exposure duration, averaging time, and particulate emission factors) be calculated on a site-specific basis. As a consequence, site-specific construction worker parameters and site-specific construction worker exposure estimates will not be calculated in the current evaluation.

Equations (3) through (8) of Appendix D, and Tables D.2 through D.4 of corresponding exposure parameters evaluate the EPA chemical PRG equations and input parameters for workers exposed to soil. Of key interest are the following changes since 1999:

- separation of traditional worker into indoor and outdoor categories (as presented in both EPA radionuclide and chemical PRG equations),

- standardization of a site-specific outdoor construction worker scenario (as presented in both EPA radionuclide and chemical PRG equations),

- separate soil adherence factors for outdoor and construction workers (as presented in EPA chemical PRG equations),

- $\quad$ separate soil ingestion rates for each worker category (as presented in both EPA radionuclide and chemical PRG equations),

- new exposed skin surface areas for each worker category (as presented in EPA chemical PRG equations), and

- use of a mechanical particulate emission factor (PEF) soil suspension factor equation model for the site-specific construction worker (as presented in EPA chemical PRG equations).

\subsection{OTHER SCENARIOS}

A trespasser scenario was evaluated in Appendix C of USACHPPM (1999). At present, EPA Region IV provides some guidance for the assessment of a trespasser scenario in their human health risk assessment bulletins (http://www.epa.gov/region4/waste/ots/healtbul.htm). To the authors' knowledge no other regulatory body presently utilizes trespasser guidance. Equations (9) and (10) of Appendix D, along with Table D.5, present the current equations and input parameters for trespasser exposure to soil. Of key interest are the following differences from a standard resident equation:

- body weight of $45 \mathrm{~kg}$ and

- exposure duration (ED) of 10 years.

An agricultural/grazing scenario was evaluated in Appendix D of USACHPPM (1999). At present, the EPA Superfund program provides some guidance for the assessment of agricultural scenarios in its radionuclide PRG calculator at http://epa-prgs.ornl.gov/radionuclides/prg_guide.shtml. Additional site-specific agricultural scenarios are present in the DOE (2000) risk assessment guidance for the Paducah Gaseous Diffusion Plant in Paducah, Kentucky. USACHPPM (2000b) also presents agricultural scenario parameters and sources. These agricultural scenarios are also presented on the Risk Assessment Information System (RAIS). Exposure parameters are presented for

- consumption of produce (fruits and vegetables),

- fish,

- beef and dairy, 
- poultry and eggs, and

- swine.

Note that the EPA Superfund radionuclide soil PRG equation for the default resident includes consumption of produce. However, Regions III, VI, and IX do not include consumption of produce in their default resident soil PRG equations.

\subsection{PARTICULATE EMISSION FACTOR-WIND}

There are no significant changes in the wind-driven particulate emission factor from USACHPPM (1999) to present. However, EPA (2002) presents a method for calculating a region-specific winddriven particulate emission factor $\left(\mathrm{PEF}_{\mathrm{w}}\right)$. Users can choose from 29 climatic zones and 6 different site areas available for calculating a region-specific $\mathrm{PEF}_{\mathrm{w}}$ in EPA (2002). The 2007 screening level values presented in this evaluation are calculated with the most conservative climatic region (Minneapolis) and site area ( 0.5 acres) for screening purposes. This combination of climatic region and site area produces the most amount of wind-generated dust available for inhalation. See Eq. (11) in Appendix D and associated table (Table D.6) for the standard equation. Regional-specific inputs need to be retrieved from EPA (2002) for calculating $\mathrm{PEF}_{\mathrm{w}}$ estimates.

\subsection{PARTICULATE EMISSION FACTOR-MECHANICAL}

EPA (2002) also presents a new method for calculating a mechanical-driven particulate emission factor $\left(\mathrm{PEF}_{\mathrm{m}}\right)$. Users can choose from the 29 climatic zones and 6 different site areas now available for calculating a region-specific $\mathrm{PEF}_{\mathrm{m}}$ in EPA 2002. The $\mathrm{PEF}_{\mathrm{m}}$ is typically used in conjunction with the site-specific outdoor construction worker. This scenario assumes site activity with heavy equipment to be actively resuspending soil. The 2007 screening level values presented in this document do not include the construction worker due to the highly variable and site-specific inputs required to calculate $\mathrm{PEF}_{\mathrm{m}}$. The $\mathrm{PEF}_{\mathrm{m}}$ equation requires inputs of the weights and numbers of vehicles that work on the site and the daily number of vehicular trips across the site. It is highly recommended that, for contaminated sites with large areas with anticipated lengthy remediation, evaluation of the $\mathrm{PEF}_{\mathrm{m}}$ be considered. See Eq. (12) in Appendix D and associated Table D.6 for the current standard approach. Regional-specific inputs must be retrieved from EPA (2002) for calculating $\mathrm{PEF}_{\mathrm{m}}$ estimates.

\subsection{VOLATILIZATION FACTOR}

There are no significant changes in calculation of the volatilization factor (VF) from USACHPPM (1999) to the present. EPA (2002) presents two methods for calculating volatilization factors. Depending on the level of site-specific information available, users can choose from regional defaults or a mass-limit approach. Twenty-nine climatic zones and six different site areas are now available for calculating region-specific wind-driven volatilization factors in EPA (2002). The 2007 screening level values presented in this document are calculated with the most conservative climatic region (Los Angeles) and site area ( 0.5 acres) for screening purposes. This combination of climatic region and site area has the soil characteristics that allow the greatest ease of volatilization and produces vapor of the greatest density. See Eq. (13) in Appendix D and associated Table D.7 for the standard equation. Regional-specific inputs must be retrieved from EPA (2002) for this calculation.

\subsection{TARGET RISK AND TARGET HAZARD INDEX}

Target cancer risk levels dictate the degree of human health protection to be achieved by risk-based cleanup standards. The degree of conservatism incorporated in the selection of applicable target 
cancer risk levels significantly affects cleanup standard calculations and associated remediation action cost. HD is the only CWA with carcinogenic SF. Target cancer risks of $1 \times 10^{-4}$ and $1 \times 10^{-5}$ have been selected for industrial and residential land uses, respectively, in accordance with accepted practice and regulatory precedent as detailed below.

Other screening tables such as EPA Regions III, VI, and IX and Soil Screening Level (SSL) all use a default target cancer risk of $1 \times 10^{-6}$. However a target risk range of $1 \times 10^{-4}$ to $1 \times 10^{-6}$ is codified in the National Contingency Plan (EPA 1990a) as a basis for remediation of Superfund sites. In the World Trade Center Indoor Environment Assessment (EPA 2003), a screening level of $1 \times 10^{-4}$ was selected based on sampling detection limits (EPA 1990b). The EPA Removal Action Level program has also selected $1 \times 10^{-4}$ as its target cancer risk (https://epa-rals.ornl.gov/). Further summarization of the risk range is available at: http://www.epa.gov/OUST/rbdm/sctrlsgw.htm. Thus, the target cancer risks employed in USACHPPM (1999) and the present analysis are the same.

Military munitions facilities located within the boundaries of the State of Maryland have historically stockpiled sulfur mustard agent (Watson and Griffin 1992). As a consequence, the Maryland Department of the Environment has addressed cancer risk assessment for sulfur mustard and other carcinogens by codifying the definition of "insignificant risk concentrations (IRC)" for toxic air pollutants to mean "a concentration of a ...toxic pollutant in an atmosphere that would result in an excess individual lifetime cancer risk of not more than 1 in $100,000\left(1 \times 10^{-5}\right)$," assuming continuous exposure for 70 years (COMAR 2005). The present analysis incorporates a residential target cancer risk of $1 \times 10^{-5}$ consistent with Maryland code and the National Contingency Plan (EPA 1990a) and is further evidence that the residential target cancer risk of $1 \times 10^{-5}$ previously employed in USACHPPM (1999) remains appropriate and protective.

The target hazard index of 1 was employed in USACHPPM (1999) and the present analysis. These target cancer risk and target hazard index values are consistent with other screening tables such as

- $\quad$ EPA Region III (http://www.epa.gov/reg3hwmd/risk/human/index.htm),

- EPA Region VI (http://www.epa.gov/earth1r6/6pd/rcra_c/pd-n/screen.htm),

- EPA Region IX (http://www.epa.gov/region09/waste/sfund/prg/index.html), and

- EPA SSL (http://rais.ornl.gov/calc_start.shtml). 


\section{COMPARISON OF RESULTING SCREENING VALUES WITH 1999 HBESLS}

This section compares the 1999 HBESLs with the newly calculated soil screening level estimates and considers any resulting differences that are a result of the changes outlined in Sect. 3. This section also evaluates the differences between the EPA radionuclide and chemical PRG equations for applicable exposure scenarios.

\subsection{RESIDENTIAL EXPOSURE SCENARIO}

With the exception of cancer toxicity values for sulfur mustard (agent HD), the residential exposure scenario parameters have not changed significantly since 1999. However, the EPA radionuclide and chemical PRG equations do present a difference. See Table 4 for the results of implementing the new models.

Table 4. Summary of residential soil screening level estimates $(\mathrm{mg} / \mathrm{kg}$ soil)

\begin{tabular}{lcc}
\hline Agent & $\begin{array}{c}\text { 1999 HBESL } \\
\text { residential soil }\end{array}$ & $\begin{array}{r}\text { 2007 Estimate: residential soil EPA } \\
\text { chemical PRG equation }\end{array}$ \\
\hline $\mathrm{HD}$ & $0.01^{a}$ & $0.19^{a}$ \\
$\mathrm{~L}$ & 0.3 & 0.45 \\
$\mathrm{GA}$ & 2.8 & 2.9 \\
$\mathrm{~GB}$ & 1.3 & 1.4 \\
$\mathrm{GD} / \mathrm{GF}$ & 0.22 & 0.25 \\
$\mathrm{VX}$ & 0.042 & 0.043 \\
\hline
\end{tabular}

${ }^{a}$ Agent HD is a carcinogen; HBESL values are calculated on the basis of a $10^{-5}$ target cancer risk and compared with the results assuming noncancer endpoints. PRG estimates in 1999 and 2007 were based on the cancer endpoint. The 2007 noncancer screening level estimate for resident, EPA chemical PRG equation is $0.258 \mathrm{mg} / \mathrm{kg}$. The most protective estimate of $0.185 \mathrm{mg} / \mathrm{kg}$ for cancer endpoints is presented above.

Table 4 shows that the 1999 residential HBESL values are more protective than estimates derived from the 2007 EPA chemical PRG equation.

\subsection{ADULT WORKER EXPOSURE SCENARIOS}

The adult outdoor worker exposure scenario parameters have changed significantly since 1999, and calculations following application of the EPA radionuclide and chemical PRG equations do provide different results. Also, the inhalation cancer toxicity values (e.g., unit risk and SF) for HD have changed, resulting in significant differences. See Table 5 for the results of implementing the new models, HD unit risk and SF.

Table 5 shows that, with the exception of HD, all 2007 outdoor worker screening level estimates are approximately $40 \%$ more protective than the 1999 HBESL outdoor worker estimates and are within a factor of 2 of each other. HD, however, exhibited an updated inhalation SF; the resulting HBESL of $1.4 \mathrm{mg} / \mathrm{kg}$ is based on the more protective results of the noncancer model. The 1999 HD HBESL is less protective than the 2007 screening level estimate but is still well within an order of magnitude. This level of difference is within the defined confidence levels of the toxicity values. 
Table 5. Summary of outdoor worker soil screening level estimates (mg/kg soil)

\begin{tabular}{lcc}
\hline Agent & $\begin{array}{c}\text { 1999 HBESL worker } \\
\text { (outdoor) }\end{array}$ & $\begin{array}{c}\text { 2007 Estimate: outdoor worker } \\
\text { superfund chemical and radionuclide } \\
\text { PRG equation }\end{array}$ \\
\hline HD & $0.3^{a}$ & $1.4^{b}$ \\
L & 3.7 & 2.9 \\
GA & 68 & 39 \\
GB & 32 & 19 \\
GD/GF & 5.2 & 3.2 \\
VX & 1.1 & 0.56 \\
\hline
\end{tabular}

${ }^{a}$ Agent HD is a carcinogen; HBESL worker values are calculated on the basis of a $10^{-4}$ target cancer risk and compared with the results assuming noncancer endpoints. 1999 PRG estimates were based on cancer endpoint.

${ }^{b} 2007$ PRG estimates were based on noncancer endpoints. The 2007 cancer screening level estimates for outdoor worker, EPA radionuclide and chemical PRG equation is $5.06 \mathrm{mg} / \mathrm{kg}$. The most protective estimate $(1.36 \mathrm{mg} / \mathrm{kg})$ is for the noncancer endpoint and is presented above.

The adult indoor worker exposure scenario parameters have changed significantly since 1999. Also, the inhalation cancer toxicity values (e.g., inhalation unit risk and SF) for HD have changed, resulting in significant differences. See Table 6 for the results of implementing the EPA chemical PRG models as well as an updated HD inhalation unit risk and SF for the indoor worker. The outcome also provides results of a sensitivity analysis in which the effects of including a residential dermal exposure route were examined. In the event of dust infiltration into an indoor work site, the dermal route should be applied to the indoor worker screening equation.

Table 6. Summary of indoor worker soil screening level estimates (mg/kg soil)

\begin{tabular}{lccc}
\hline Agent & $\begin{array}{c}\text { 1999 HBESL } \\
\text { worker (outdoor) }\end{array}$ & $\begin{array}{c}\text { 2007 Estimate: } \\
\text { indoor worker } \\
\text { w/o dermal }\end{array}$ & $\begin{array}{c}\text { 2007 Estimate: indoor } \\
\text { worker w/residential } \\
\text { dermal (modified EPA } \\
\text { chemical PRG equation) }\end{array}$ \\
\hline HD & $0.3^{a}$ & $1.4^{b}$ & $1.4^{b}$ \\
L & 3.7 & 204 & 7.3 \\
GA & 68 & 79 & 72 \\
GB & 32 & 40 & 36 \\
GD/GF & 5.2 & 8.1 & 6.4 \\
VX & 1.1 & 1.2 & 1.1 \\
\hline
\end{tabular}

$\mathrm{DF}_{\mathrm{i}}=$ Dilution factor

${ }^{a}$ Agent HD is a carcinogen; HBESL values are calculated on the basis of a $10^{-4}$ target cancer risk and compared with the results assuming noncancer endpoints. 1999 PRG estimates were based on cancer endpoint.

${ }^{b} 2007$ PRG estimates were based on noncancer endpoints. The 2007 cancer screening level estimate for indoor worker, EPA chemical PRG equation is $5.1 \mathrm{mg} / \mathrm{kg}$. The 2007 cancer screening level estimate for indoor worker, modified EPA chemical PRG equation is $5.01 \mathrm{mg} / \mathrm{kg}$. The most protective estimates (for the noncancer endpoint) are presented above.

Table 6 shows that all 2007 indoor worker screening level estimates calculated following the EPA chemical PRG equations are less protective than the 1999 HBESL (outdoor) worker estimates. With 
the exception of VX, 2007 indoor worker screening level estimates calculated following the EPA chemical PRG equations are less protective (sometimes by several orders of magnitude) than the 1999 HBESLs for an outdoor worker. HBESL estimates for agent VX are relatively stable and have not changed to any great extent.

Table 6 indicates that following the current EPA chemical PRG equations for the vesicant agent $\mathrm{L}$ results in an increase in the HBESL estimate by approximately 2 orders of magnitude (to $204 \mathrm{mg} / \mathrm{kg}$ soil) when compared to the 1999 HBESL estimate (which incorporated dermal absorption to derive the HBESL estimate of $3.7 \mathrm{mg} / \mathrm{kg}$ soil, which is protective for skin blister injury). By employing the 2007 EPA protocol (of no dermal exposure component), indoor worker skin exposure to soil at the 2007 screening level estimate of $204 \mathrm{mg} / \mathrm{kg}$ soil poses an increased risk of vesicant skin damage. As a consequence, the present assessment tests the addition of the dermal route to the indoor worker evaluation by inclusion of the residential dermal exposure parameters. The present analysis considers that residential dermal exposure parameters for agent $\mathrm{L}$ more closely characterize indoor worker conditions and behavior when compared to outdoor worker dermal exposure parameters for this compound. The resulting 2007 screening level estimate of $7.3 \mathrm{mg} / \mathrm{kg}$ soil is less protective than the $1999 \mathrm{HBESL}$ of $3.7 \mathrm{mg} / \mathrm{kg}$; however, $7.3 \mathrm{mg} / \mathrm{kg}$ soil is protective of acute exposure and resulting vesicant skin damage.

The 1999 worker (industrial) HBESLs fall within the order of magnitude range of values calculated using the two separate 2007 indoor and outdoor worker scenario models currently used in chemical PRGs by EPA. Since this is within the assumed confidence range of the calculated values, the 1999 industrial (i.e., adult worker) scenario HBESLs are still considered appropriate screening criteria. 



\section{PRESENTATION OF DEGRADATION PRODUCT SCREENING LEVEL ESTIMATES}

This section presents the newly calculated soil screening level estimates for critical agent degradation products.

\subsection{RESIDENTIAL EXPOSURE SCENARIO}

See Table 7 for the residential soil screening levels for degradation products.

Table 7. Summary of residential soil screening level estimates (mg/kg soil)

\begin{tabular}{lc}
\hline \multicolumn{1}{c}{ Agent } & $\begin{array}{c}\text { 2007 Estimate: residential soil EPA } \\
\text { chemical PRG equation }\end{array}$ \\
\hline Arsenic & $3.9 \times 10^{0^{a}}$ \\
Thiodiglycol & $2.4 \times 10^{4}$ \\
Lewisite oxide & $6.1 \times 10^{0}$ \\
EA 2192 & $4.7 \times 10^{-2}$ \\
EMPA & $1.7 \times 10^{3}$ \\
MPA & $1.2 \times 10^{3}$ \\
IMPA & $6.1 \times 10^{3}$ \\
\hline
\end{tabular}

${ }^{a}$ Arsenic is a carcinogen; screening level values are calculated on the basis of a residential $10^{-5}$ target cancer risk and compared with the results assuming noncancer endpoints. PRG estimates for elemental arsenic were based on the (most protective) cancer endpoint. The 2007 noncancer arsenic screening level estimate for a child resident is $21.6 \mathrm{mg} \mathrm{As} / \mathrm{kg}$. The most protective estimate of $3.89 \mathrm{mg} \mathrm{As} / \mathrm{kg}$ for cancer endpoints is presented in Table 7 above.

\subsection{ADULT WORKER EXPOSURE SCENARIOS}

See Table 8 for the outdoor worker soil screening levels for degradation products.

Table 8. Summary of outdoor worker soil screening level estimates (mg/kg soil)

\begin{tabular}{lc}
\hline \multicolumn{1}{c}{ Agent } & $\begin{array}{c}\text { 2007 Estimate: outdoor worker soil EPA } \\
\text { chemical PRG equation }\end{array}$ \\
\hline Arsenic & $1.8 \times 10^{2^{a}}$ \\
Thiodiglycol & $6.0 \times 10^{4}$ \\
Lewisite oxide & $1.5 \times 10^{1}$ \\
EA 2192 & $6.8 \times 10^{-1}$ \\
EMPA & $4.2 \times 10^{3}$ \\
MPA & $3.0 \times 10^{3}$ \\
IMPA & $1.5 \times 10^{4}$ \\
\hline
\end{tabular}

${ }^{a}$ Arsenic is a carcinogen; screening level values for workers are calculated on the basis of a $10^{-4}$ target cancer risk and compared with the results assuming noncancer endpoints. PRG estimates for elemental arsenic were based on the (most protective) cancer endpoint. The 2007 noncancer screening level estimate for AN outdoor worker is $284 \mathrm{mg}$ As $/ \mathrm{kg}$. The most protective endpoint estimate for cancer (177 mg As/ $\mathrm{kg}$ ) is presented in Table 8 above. 
See Table 9 for the results of implementing the EPA chemical PRG models for the indoor worker. The outcome also provides results of a sensitivity analysis in which the effects of including a residential dermal exposure route were examined.

Table 9. Summary of indoor worker soil screening level estimates (mg/kg soil)

\begin{tabular}{lcc}
\hline \multicolumn{1}{c}{ Agent } & $\begin{array}{c}\text { 2007 Estimate: indoor } \\
\text { worker w/o dermal }\end{array}$ & $\begin{array}{c}\text { 2007 Estimate: indoor worker w/ } \\
\text { residential dermal (modified EPA } \\
\text { chemical PRG equation) }\end{array}$ \\
\hline Arsenic & $3.8 \times 10^{2^{a}}$ & $3.3 \times 10^{2^{a}}$ \\
Thiodiglycol & $8.2 \times 10^{5}$ & $1.5 \times 10^{5}$ \\
Lewisite oxide & $2.0 \times 10^{2}$ & $3.6 \times 10^{1}$ \\
EA 2192 & $1.2 \times 10^{0}$ & $1.2 \times 10^{0}$ \\
EMPA & $5.7 \times 10^{4}$ & $1.0 \times 10^{4}$ \\
MPA & $4.1 \times 10^{4}$ & $7.3 \times 10^{3}$ \\
IMPA & $2.0 \times 10^{5}$ & $3.6 \times 10^{4}$ \\
\hline
\end{tabular}

${ }^{a}$ Arsenic is a carcinogen; screening level values for workers are calculated on the basis of a $10^{-4}$ target cancer risk and compared with the results assuming noncancer endpoints. PRG estimates for elemental arsenic were based on the (most protective) cancer endpoint. The 2007 noncancer screening level estimate for indoor worker without dermal is $613 \mathrm{mg} \mathrm{As} / \mathrm{kg}$; the most protective endpoint estimate for indoor worker (w/o dermal) is that for cancer ( $380 \mathrm{mg} \mathrm{As} / \mathrm{kg}$ ) and is presented in Table 9 above. The 2007 noncancer screening level estimate for indoor worker using the modified EPA chemical PRG equation with dermal is $539 \mathrm{mg} / \mathrm{kg}$; the most protective endpoint estimate for indoor worker (w/dermal) is that for cancer (334 mg As/kg) and is presented in Table 9 above. 


\section{APPLICATIONS OF HBESLS}

The original and primary objective for development of HBESL values was to address potential longterm or chronic exposures to residual concentrations of $\mathrm{CW}$ agents at Army environmental restoration and Formerly Used Defense (FUD) sites (USACHPPM 1999). This objective remains unchanged and fulfills site assessment needs by use as "action or no-action" criteria. Screening levels are used to evaluate whether or not potentially contaminated soils need to be remediated or a site-specific risk evaluation should be performed. They may also be used to determine if an area has been adequately cleaned. If actual soil concentrations were to fall below an established screening level for a specified scenario, no further "action" would be deemed necessary. If above the designated screening level, various "action" options would be required.

The HBESLs have also been identified as criteria to be used as screening as well as "clearance" criteria in the event of catastrophic CWA releases. For example, HBESLs have specifically been incorporated into planning and response guidance developed for unintentional release from a $\mathrm{CW}$ agent munitions disposal site (Chemical Stockpile Emergency Planning and Preparedness (CSEPP) Recovery Plan Workbook, 2003). In particular, world events since 1999 have drawn attention to the practical need for health-based environmental screening levels for decision-making use in the event of a chemical terrorist event or exercises simulating such events. Such was the case for the TOPOFF 3 Sulfur Mustard Exercise of April 2005, which simulated an attack on civilians and civilian infrastructure with vesicant agent HD (EPA 2005c). In this exercise, HBESL values for HD from USACHPPM (1999) were used to establish the analytical protocol for laboratory assessment and screening of simulated soil and concrete samples removed from the presumptive hot zone; the results of this screening analysis were critical to developing an objective basis for phased civilian reoccupancy of the affected areas. It was noted, however, that the use of HBESLs as screening/clearance criteria for samples of soil and destructive samples of porous media, such as concrete, in this exercise was only part of a broader sampling strategy. In fact, the primary form of sampling described was near-surface air sampling and headspace sampling (e.g., monitoring of any off-gassing of agent from a container of sampled soil). For these types of samples, comparison to established civilian air exposure guidelines was agreed upon (see Appendix B, Table B.2). In addition, surface water and decontamination water needs to be screened against established field drinking water standards (see Appendix B).

Further, advance availability of environmental screening levels developed with currently accepted models and input parameters allows a means to objectively determine adequacy of analytical detection capabilities prior to advent of a crisis. As a consequence, technical improvements and resources can be directed in a systematic and efficient manner so as to maintain focus on the most toxic or significant compounds. This is just one way in which application of screening levels can help optimize resources and minimize unproductive expenditures of time and funds.

Note, however, that screening levels may not be appropriate for all situations because certain technical assumption criteria must be met, and all stakeholders (e.g., state and local regulators, public, and Army personnel) must agree to their appropriate use. Guidance on application of screening levels can be obtained from EPA (1996a, 1989). In addition, example risk assessment applications are provided in USACHPPM (2000). 



\section{RECOMMENDATIONS}

This section presents recommendations resulting from assessing differences and implications of the 2007 screening level estimates using both the EPA chemical PRG and EPA radionuclide equations vs the 1999 HBESLs. Also determined are current recommended and protective screening level values. Applications, procedures, and refinements to screening level derivation and use are also recommended.

\subsection{RECOMMENDATIONS REGARDING EPA CHEMICAL PRG EQUATIONS}

The results of this 2007 evaluation support the finding that EPA chemical PRG equations are preferable to the EPA radionuclide PRG equations in screening level default analysis. The EPA chemical PRG equations were selected because they did not include the "inhalation expression," which provides less protective values. However the "inhalation expression" could be used in certain site-specific scenarios.

\subsection{RECOMMENDATIONS OF 1999 HBESLS OVER THE 2007 SCREENING LEVEL VALUES}

After comparing the 1999 HBESL estimates with current results, this analysis has determined that the 1999 HBESL estimates are still protective for residents and workers. [The 1999 and 2007 residential values are nearly identical and the 1999 worker (industrial) HBESLs fall within the range of values calculated using the indoor and outdoor worker scenario models.] However, the new PRG models and equations presented in this screening level evaluation do allow for site-specific (e.g., unique chemical warfare agent site) assessment using technically sound principles. Further, the present findings offer opportunities for refinement of occupational assessments by separate consideration of indoor and outdoor worker exposure assumptions (see Sects. 3 and 4).

Given that EPA's final position on separate Tier 1 screening levels for indoor and outdoor worker screening assessments has not yet been released as of May 2007, the authors of this assessment find that the 1999 HBESL estimates (USACHPPM 1999) are still appropriate for screening residential as well as nonresidential sites. When EPA finalizes and documents a position on the matter of indoor and outdoor worker screening assessments, site-specific risk assessments should make use of modified models and criteria.

Table 10 presents HBESL values recommended for current use in the absence of site-specific assessment.

Table 10. Recommended screening level values ${ }^{a}$

\begin{tabular}{lcc}
\hline Agent & $\begin{array}{c}\text { Current residential soil } \\
\text { screening levels } \\
(\mathbf{m g} / \mathbf{k g})\end{array}$ & $\begin{array}{c}\text { Industrial soil } \\
\text { screening levels } \\
(\mathbf{m g} / \mathbf{k g})\end{array}$ \\
\hline $\mathrm{HD}$ & 0.01 & 0.3 \\
$\mathrm{~L}$ & 0.3 & 3.7 \\
$\mathrm{GA}$ & 2.8 & 68 \\
$\mathrm{~GB}$ & 1.3 & 32 \\
$\mathrm{GD} / \mathrm{GF}$ & 0.22 & 5.2 \\
$\mathrm{VX}$ & 0.042 & 1.1 \\
\hline
\end{tabular}

${ }^{a}$ Reflects validation of values published in USACHPPM (1999). 


\subsection{OTHER RECOMMENDATIONS}

It is also recommended that

- Air monitoring should accompany any soil sampling. Air samples should be compared with use of established air criteria (see Appendix B);

- Evaluation of drinking water should be focused on the acute hazard (i.e., exposures lasting less than 7 d) (see Appendix C). USACHPPM (1999) evaluated the potential for ground water contamination from $\mathrm{CW}$ and determined that the groundwater contamination scenario was not plausible. In addition, the long-term contamination of large bodies of water with $\mathrm{CW}$ for an extended period of time was also considered implausible due to hydrolysis, degradation, and dilution. No new information since 1999 has altered this finding; and

- Certain scenarios such as the trespasser, agricultural, and site-specific construction worker scenarios should be considered on a site-specific basis using equations in Appendix D. 


\section{REFERENCES}

ATSDR (Agency for Toxic Substances and Disease Registry). 2005. Draft Toxicological Profile for Arsenic. U.S. Department of Health and Human Services. Washington, D.C. http://www.atsdr.cdc.gov/toxprofiles/tp2.pdf

Bartlett, P. D., and C. G. Swain. 1949. "Kinetics of hydrolysis and displacement reactions of $\beta$ - $\beta$ '(dichlordiethyl sulfide, Mustard Gas) and of $\beta$-chloro- $\beta$ 'hydroxidediethyl sulfide (mustard chlorohydrin)." J. Amer. Chem. Soc. 71: 1406-1415.

Bartelt-Hunt, S. L., M. A. Barlaz, D. R. U. Knappe, and P. Kjeldsen. 2006. "Fate of chemical warfare agents and toxic industrial chemicals in landfills." Environ. Sci. Technol. 40: 4219-4225.

Bausum, H. T., G. Reddy, and G. J. Leach. 1999. Suggested interim estimates of the reference dose $(R f D)$ and reference concentration $(R f C)$ for certain key breakdown products of chemical agents. Report to the USACHPPM Chemical Standards Working Group, December 10, 1998. U.S. Army Center for Health Promotion and Preventive Medicine, Aberdeen Proving Ground, MD.

Bossle, P. C., J. J. Martin, E. W. Sarve, and H. Z. Sommer. (1983). "High-performance liquid chromatography analysis of alkyl methylphosphonic acids by derivatization." J. Chromatog. 267, 209-212.

Britton, K. B., and C. L. Grant. 1988. Prediction of Octanol-Water Partition Coefficients of Organophosphates. Evaluation of structure-function relationships. Special Report 88-11, U.S. Army Corps of Engineers Cold Regions Research and Engineering Laboratory, Hanover, NF.

Buswell, A. M., C. C. Price, R. M. Roberts, C. W. Smith, and B. H. Velzen. 1944. The chemistry of certain arsenical chemical warfare agents as water contaminants. Report No. OSRD-4193. Division 9 of the National Defense Research Committee of the Office of Scientific Research and Development. Available from Chemical Biological Information Analysis Center, Aberdeen Proving Ground, MD (CB-109156)(as cited in DA 2005b).

Carpenter, T. J., and T. E. Hill. 1988. Methods for Demolition of Building E5625. U.S. Army Chemical Research, Development and Engineering Center, Aberdeen Proving Ground, MD.

COMAR (Code of Maryland Regulations). 2005. "Definitions, Toxic Air Pollutants." Title 26 (Department of Environment), Part 2, Subtitle 11 (Air Quality), [Title 26.11.15.01.B.(8)]. State of Maryland, Office of Secretary of State, Division of State Documents (Supplement 18 issued September 2005) (www.dsd.state.md.us/comar/26/26.11.15.01.htm).

Cooper, W. A. (1990). A Data Base on Persistent CW Agents on Terrain. AD-B149 283, Chemical Research, Development \& Engineering Center, Aberdeen Proving Ground, MD.

CSEPP (Chemical Stockpile Emergency Preparedness Program). 2003. CSEPP Recovery Plan Workbook, U.S. Army Soldier and Biological Chemical Command, Federal Emergency Management Agency, and CSEPP Reentry and Recovery Working Group. Aberdeen Proving Ground, MD (April 2003).

DA (Department of the Army). 1974. Chemical Agent Data Sheets. Edgewood Arsenal Special Report, EO-SR-74001. Department of the Army, Edgewood Arsenal, Aberdeen Proving Ground, MD.

DA (Department of the Army). 1990. "Occupational health guidelines for the evaluation and control of occupational exposure to mustard agents H, HD, and HT." Pamphlet 40-173, Headquarters, Department of the Army, Washington, D.C.

DA (Department of the Army). 1991. "Occupational health guidelines for the evaluation and control of occupational exposure to nerve agents GA, GB, GD, and VX." Pamphlet 40-8, Headquarters, Department of the Army, Washington, D.C.

DA (Department of the Army). 2004. Implementation guidance policy for revised airborne exposure limits for $G B, G A, G D, G F, V X, H, H D$, and $H T$. Office of the Assistant Secretary (Installations and Environment), Department of the Army, Washington, D.C. (9 June). 
DA (Department of the Army). 2005a. "Sanitary Control and Surveillance of Field Water Supplies." Technical Bulletin (TB) Med 577. Headquarters, Department of the Army, The Pentagon, Washington D.C. (December 2005) (Approved for public release, distribution unlimited).

DA (Department of the Army). 2005b. Potential Military Chemical/Biological Agents and Compounds. Field Manual (FM) 3-11.9. Army, Marine Corps, Navy, Air Force Multiservice Tactics, Techniques and Procedures. Available at Army Knowledge Online, www.us.army.mil (Approved for public release, distribution unlimited).

DHHS (U.S. Department of Health and Human Services). 1988. "Final recommendations for protecting the health and safety against potential adverse effects of long-term exposure to low doses of agents GA, GB, VX, mustard agent (H, HD, T) and Lewisite (L)." Centers for Disease Control. Fed. Reg. 53: 8504-8507.

DHHS (U.S. Department of Health and Human Services). 2003. "Final recommendations for protecting human health from potential adverse effects of exposure to agents GA (Tabun), GB (Sarin), and VX." Centers for Disease Control and Prevention. Fed. Reg. 68: 58348-58351.

DHHS (U.S. Department of Health and Human Services). 2004. "Interim recommendations for airborne exposure limits for chemical warfare agents H and HD (sulfur mustard)," Centers for Disease Control and Prevention. Fed. Reg. 69: 24164-24168.

DOE (U.S. Department of Energy). 2000. Methods for Conducting Risk Assessments and Risk Evaluations at the Paducah Gaseous Diffusion Plant, Paducah, Kentucky. Volume 1. Human Health. DOE/OR/07-1506\&D2. U.S. Department of Energy, Office of Environmental Management, Environmental Management Activities at the Paducah Gaseous Diffusion Plant Paducah, Kentucky.

EPA (U.S. Environmental Protection Agency). 1989. Risk Assessment Guidance for Superfund: Volume I-Human Health Evaluation Manual (Part A). OSWER Directive EPA/540/1-89/002. Office of Emergency and Remedial Response, U.S. Environmental Protection Agency, Washington, D.C., 1989.

EPA (U.S. Environmental Protection Agency). 1990a. "National oil and hazardous substances pollution contingency plan-final rule." Federal Register 55: CFR Part 300:666, Appendix C.

EPA (U.S. Environmental Protection Agency). 1990b. Exposure Factors Handbook. EPA/600/ 8-89/043. Office of Health and Environmental Assessment, Washington, D.C., May 1989 (March 1990).

EPA (U.S. Environmental Protection Agency). 1991a. Upper-bound Quantitative Cancer Risk Estimate for Populations Adjacent to Sulfur Mustard Incineration Facilities. EPA/600/8-91/053. Office of Research and Development, U.S. Environmental Protection Agency, Washington, D.C.

EPA (U.S. Environmental Protection Agency). 1991b. Risk Assessment Guidance for Superfund: Volume I-Human Health Evaluation Manual (Part C, Risk Evaluation of Remedial Alternatives). OSWER Directive 9285.7-01C. Office of Emergency and Remedial Response, U.S. Environmental Protection Agency, Washington, D.C., 1991.

EPA (U.S. Environmental Protection Agency). 1991c. Risk Assessment Guidance for Superfund: Volume I-Human Health Evaluation Manual (Part B, Development of Risk-based Preliminary Remediation Goals). OSWER Directive 9285.7-01B. Office of Emergency and Remedial Response, U.S. Environmental Protection Agency, Washington, D.C., 1991.

EPA (U.S. Environmental Protection Agency). 1996. Soil Screening Guidance: Technical Background Document. Office of Solid Waste and Emergency Response, Washington, D.C., EPA/540/R-95/128 (Publication 9355.4-17A).

EPA (U.S. Environmental Protection Agency). 2000b. Soil Screening Guidance for Radionuclides: Technical Background Document. U.S. Environmental Protection Agency, Office of Radiation and Indoor Air, Office of Solid Waste and Emergency Response, October 2000. Publication 9355.4-16, EPA/540-R-00-006, PB2000 963306. 
EPA (U.S. Environmental Protection Agency). 2002. Supplemental Guidance for Developing Soil Screening Levels for Superfund Sites. U.S. Environmental Protection Agency, Office of Solid Waste and Emergency Response, December 2002. Directive 9355.4-24.

EPA (U.S. Environmental Protection Agency). 2003. World Trade Center Indoor Environmental Assessment: Selecting Contaminants of Potential Concern and Setting Health-Based Benchmarks. Prepared by the Contaminants of Potential Concern (COPC) Committee of the World Trade Center Indoor Task Force Working Group. (May 2003). Available online at www.epa.gov/WTC/copc benchmark.

EPA 2004 (U.S. Environmental Protection Agency). Risk Assessment Guidance for Superfund: Volume I - Human Health Evaluation Manual [Part E, Supplemental Guidance for Dermal Risk Assessment (Final)]. OSWER Directive 9285.7-02EP. Office of Superfund Remediation and Technology Innovation, U.S. Environmental Protection Agency, Washington, D.C., July 2004.

EPA (U.S. Environmental Protection Agency). 2005a. "Arsenic.” IRIS online database. Washington, D.C.: U.S. Environmental Protection Agency. Retrieved February 21, 2005.

EPA (U.S. Environmental Protection Agency). 2005b. Toxicological Review of Phosgene. EPA/635/R-06-001.

EPA (U.S. Environmental Protection Agency). 2005c. (TOPOFF 3) Email sent April 26, 2006, Mark Mjoness, EPA Office of Emergency Management and associated attachments and follow on teleconference: Subject: Interagency Technical Expert Panel-EOC Event Room 1Additional Meeting Documents (establishes the clearance level agreed upon by EPA, OSHA, CDC/NIOSH for the HD TOPOFF Exercise Scenario).

EPA (U.S. Environmental Protection Agency). 2007. "EPA Region 6 Human Health MediumSpecific Screening Levels." http://www.epa.gov/earth1r6/6pd/rcra_c/pd-n/screen.htm. U.S. Environmental Protection Agency, Region 6, Dallas, Texas, February 21, 2007.

Epstein, J. 1974. "Properties of GB in water." J. Am. Water Works Assoc. 66: 31-37.

Franke, S. 1982. Textbook of Military Chemistry, Vol. 1. USAMIIA-HT-039-82, AD B062913. Defense Technical Information Center, Alexandria, Virginia.

HQDA (Headquarters, Department of the Army). 1999. "Derivation of health-based environmental screening levels (HBESL) for chemical warfare agents." Memorandum (28 May 1999). Department of the Army, Office of the Assistant Secretary (Installations, Logistics and the Environment), Army Pentagon, Washington, D.C.

Howard, P. H., and W. M. Meylan (Eds.). (1997). Handbook of Physical Properties of Organic Chemicals. Lewis Publishers, New York.

MacNaughton, M. G., and J. H. Brewer. 1994. Environmental Chemistry and Fate of Chemical Warfare Agents, Final Report, SwRI Project 01-5864, Southwest Research Institute, San Antonio, Texas.

Major, M. (1998). Memorandum for MCHB-TS-EHRARCP (August 5, 1998).

McGuire, R. R., J. S. Haas, and R. J. Eagle. 1993. The Decay of Chemical Weapons Agents under Environmental Conditions. UCRL-ID-114107, Lawrence Livermore National Laboratory Report, Lawrence, California.

Michel, H. O., J. Epstein, R. R. Plapinger, and J. H. Fleisher. (1962). EA 2192: A novel anticholinesterase (U). Report No. CRDLR 3135. Biochemical Research Division, Chemical Corps Research and Development Command, Chemical Research and Development Laboratories, Army Chemical Center, Aberdeen Proving Ground, Maryland.

Munro, N. B., S. S. Talmage, G. D. Griffin, L. C. Waters, A. P. Watson, J. F. King, and V. Hauschild. 1999. "The sources, fate, and toxicity of chemical warfare agent degradation products." Environ. Health Persp., 107: 933-974.

Murdock, P., W. Kilpatrick, and S. Love. 2004. "Technical Note: Response to questions regarding agent fate testing: Effects of water on previously contaminated surfaces." AFRL/HEPC CBD Chemical and Biological Defense Team. 
National Research Council (NRC). 1999. Health risk assessments for oral exposure to six chemicalwarfare agents. Committee on Toxicology, National Research Council, National Academies Press, Washington, D.C.

National Research Council (NRC). 2003. Acute Exposure Guideline Levels for Selected Airborne Chemicals, Vol. 3. "Appendix 1, Nerve agents GA, GB, GD, GF, and VX" (pp. 15-300); "Appendix 2, Sulfur mustard" (pp. 301-383). Committee on Toxicology, National Research Council, National Academies Press, Washington, D.C.

Opresko, D. M., R. A. Young, A. P. Watson, R. A. Faust, S. S. Talmage, R. H. Ross, K. A. Davidson, J. King, and V. Hauschild. (2001). "Chemical warfare agents: Current status of oral reference doses." Rev. Environ. Contam. Toxicol. 172: 65-85.

OTSG (Office of the Army Surgeon General). 2000. "Chronic toxicological criteria for chemical warfare compounds." Memorandum MCHD-CG-PPM. Dept. of the Army, Office of the Surgeon General, Falls Church, VA. (16 Feb. 2000) (signed by BG Lester Martinez-Lopez, Functional Proponent for Preventive Medicine).

RAIS. 2007. “The Risk Assessment Information System.” In progress. University of Tennessee, Knoxville and Oak Ridge National Laboratory, Oak Ridge, TN. http://rais.ornl.gov/

Reddy, G., M. A. Major, and G. J. Leach. 2005. Toxicity assessment of thiodiglycol. International J. Toxicol. 24: 435-442.

Rewick, R. T., M. L. Shumacher, and D. L. Haynes. 1986. The UV absorption spectra of chemical agents and simulants. Appl. Spectroscopy 40: 152-156.

Rosenblatt, D. H., T. A. Miller, J. C. Dacre, I. Muul, and D. R. Cogley. 1975. Problem Definition Studies on Potential Environmental Pollutants. II. Physical, Chemical, Toxicological, and Biological Properties of 16 Substances. Technical Report 7509; AD AO30428. U.S. Army Medical Bioengineering Research and Development Laboratory, Fort Detrick, MD.

Rosenblatt, D. H., M. J. Small, T. A. Kimmell, and A. W. Anderson. 1995. Agent Decontamination Chemistry: Technical Report. U.S. Army Test and Evaluation Command (TECOM) Technical Support, Phase 1. Prepared for Environmental Quality Office, U.S. Army Test and Evaluation Command. Prepared by Argonne National Laboratory.

Samuel, J. B., E. C. Penski, and J. J. Callahan. 1983. Physical Properties of Standard Agents, Candidate Agents, and Related Compounds at Several Temperatures (U), Special Publications ARCSL-SP-83015. Aberdeen Proving Ground, MD: Chemical Systems Laboratory (June).

Small, M. J. 1984. Compounds Formed from the Chemical Decontamination of HD, GB, and VX and Their Environmental Fate. Technical Report 8304, U.S. Army Medical Bioengineering Research and Development Laboratory, Fort Detrick, Frederick, MD; AD A149515.

Szafraniec, L. J., L. L. Szafraniec, W. T. Beaudry, and J. R. Ward. 1990. On the Stoichiometry of Phosphonothiolate Ester Hydrolysis. ADA-250773. Aberdeen Proving Ground, MD: U.S. Army Chemical Research, Development and Engineering Center.

Talmage, S. S., A. P. Watson, V. Hauschild, J. F. King, and N. B. Munro. 2007(a). "Chemical warfare agent degradation and decontamination." Current Organic Chemistry 11: 285-298.

Talmage, S. S., N. B. Munro, A. P. Watson, J. F. King, and V. Hauschild. 2007(b). "The Fate of Chemical Warfare Agents in the Environment," Chapter 4, pp. 89-125 in T. Marrs, R. L. Maynard, and F. R. Sidell (Eds.). Chemical Warfare Agents: Toxicology and Treatment (2nd ed.). John Wiley and Sons, Ltd., Chichester, West Sussex, UK.

Thacker, S. B. 1994. Letter dated 24 June 1994 establishing "Recommended Acute Threshold Effects Levels for Determining Emergency Evacuation Distances in the CSEPP Program" from Dr. S. B. Thacker, Assistant Surgeon General, Acting Director, National Center for Environmental Health, Center for Disease Control and Protection, U.S. Department of Health and Human Services, to Col. J. M. Coverstone, Deputy for Chemical Demilitarization, Office of the Assistant Secretary (I, L \& E), Washington, D.C. 
USACHPPM (U.S. Army Center for Health Promotion and Preventive Medicine). 1999. Derivation of Health-based Environmental Screening Levels for Chemical Warfare Agents, A Technical Evaluation. U.S. Army CHPPM, Aberdeen Proving Ground, MD (March 1999).

USACHPPM (U.S. Army Center for Health Promotion and Preventive Medicine). 2000a. Evaluation of Airborne Exposure Limits for Sulfur Mustard: Occupational and General Population Exposure Criteria. U.S. Army CHPPM, Aberdeen Proving Ground, MD (November 2000).

USACHPPM (U.S. Army Center for Health Promotion and Preventive Medicine). 2000b. Joliet/Midewin Health Risk Assessment Team. Preliminary Remediation Goals for Prairie Workers. Prepared for the Joliet Army Ammunition Plant and Midewin National Tallgrass Prairie, Will County, Illinois. U.S. Army CHPPM, Aberdeen Proving Ground (MD) (September 29, 2000).

USACHPPM (U.S. Army Center for Health Promotion and Preventive Medicine). 2004. Acute Toxicity Estimation and Operational Risk Management of Chemical Warfare Agent Exposures. USACHPPM Report No. 47-EM-5863-04. U.S. Army CHPPM, Aberdeen Proving Ground, MD (May 2004).

USAF (U.S. Air Force). 2003. Fate of Agent: Czech Republic Field Trials: Results from 2000 and 2001, Trial Data, Vol. 2, Wright Patterson Air Force Base, AFRL-HE-WP-TR-2003-0055.

Wagner, G. W., R. J. O'Connor, and L. R Procell. 2001. "Preliminary study on the fate of VX in concrete." Langmuir 17, 4336-4341.

Watson, A. P., and G. D. Griffin. 1992. Toxicity of vesicant agents scheduled for destruction by the chemical stockpile disposal program. Environ. Health Perspect. 98: 259-280.

Williams, J. M., B. Rowland, M. T. Jeffery, G. S. Groenewold, A. D. Appelhans, G. L. Gresham, and J. E. Olson. 2005. Degradation kinetics of VX on concrete by secondary ion mass spectrometry. Langmuir 21, 2386-2390.

Yang, Y.-C., L. L. Szafraniec, W. T. Beaudry, and D. K. Rohrbaugh. 1990. "Oxidative detoxification of phosphonothiolates." J. Am. Chem. Soc. 112: 6621-6627.

Yang, Y.-C., L. L. Szafraniec, and W. T. Beaudry. 1993. "Perhydrolysis of nerve agent VX.” J. Org. Chem., 58: 6964-6965. 

Appendix A

1999 REGIONAL, OSWER, AND HBESL SCREENING VALUES 



\section{Appendix A}

\section{REGIONAL, OSWER, AND HBESL SCREENING VALUES}

This appendix contains the RBC, PRGs, SSLs, and HBESLs as presented in USACHPPM (1999;

Derivation of Health-based Environmental Screening Levels for Chemical Warfare Agents, A Technical Evaluation).

Table A.1. Summary of previous screening level values (from USACHPPM 1999)

\begin{tabular}{|c|c|c|c|c|c|c|c|c|}
\hline & $\begin{array}{l}\text { Region } \\
\text { III } \\
\text { resident } \\
\text { soil } \\
\text { ingestion } \\
\text { RBC }\end{array}$ & $\begin{array}{c}\text { Region } \\
\text { III } \\
\text { industrial } \\
\text { soil } \\
\text { ingestion } \\
\text { RBC }\end{array}$ & $\begin{array}{l}\text { Region } \\
\text { IX } \\
\text { resident } \\
\text { soil total } \\
\text { PRG }\end{array}$ & $\begin{array}{l}\text { Region } \\
\text { IX } \\
\text { industrial } \\
\text { soil total } \\
\text { PRG }\end{array}$ & $\begin{array}{l}\text { OSWER } \\
\text { resident } \\
\text { soil } \\
\text { ingestion } \\
\text { SSL }\end{array}$ & $\begin{array}{c}\text { OSWER } \\
\text { resident } \\
\text { soil } \\
\text { inhalation } \\
\text { of dust } \\
\text { SSL }\end{array}$ & $\begin{array}{c}\text { OSWER } \\
\text { resident } \\
\text { soil } \\
\text { inhalation } \\
\text { of } \\
\text { volatiles } \\
\text { SSL } \\
\end{array}$ & $\begin{array}{c}\text { OSWER } \\
\text { resident soil } \\
\text { migration to } \\
\text { groundwater } \\
\text { SSL }\end{array}$ \\
\hline \multicolumn{9}{|c|}{ Noncancer-derived value $(\mathrm{mg} / \mathrm{kg})$} \\
\hline HD & 0.55 & 14 & 0.4 & 4.5 & 0.55 & $1.4 \times 10^{-5}$ & 5.9 & Site-specific $^{a}$ \\
\hline VX & 0.047 & 1.2 & 0.042 & 1.1 & 0.047 & 410 & 0.3 & Site-specific $^{a}$ \\
\hline GB & 1.6 & 41 & 1.3 & 32 & 1.6 & 4100 & 0.53 & Site-specific $^{a}$ \\
\hline GA & 3.1 & 82 & 2.8 & 68 & 3.1 & 4100 & 0.8 & Site-specific $^{a}$ \\
\hline GD & 0.31 & 8.2 & 0.22 & 5.2 & 0.31 & 4100 & 0.18 & Site-specific ${ }^{a}$ \\
\hline $\mathrm{L}$ & 7.8 & 200 & 0.3 & 3.7 & 7.8 & $4.1 \times 10^{-6}$ & $\mathrm{NA}^{b}$ & $\mathrm{NA}^{c}$ \\
\hline \multicolumn{9}{|c|}{ Cancer-derived value $(\mathrm{mg} / \mathrm{kg})$} \\
\hline HD & 0.83 & 74 & 0.01 & 0.3 & 0.83 & 378 & 0.016 & Site-specific $^{a}$ \\
\hline VX & $\mathrm{NC}$ & $\mathrm{NC}$ & $\mathrm{NC}$ & $\mathrm{NC}$ & $\mathrm{NC}$ & $\mathrm{NC}$ & $\mathrm{NC}$ & $\mathrm{NC}$ \\
\hline GB & $\mathrm{NC}$ & $\mathrm{NC}$ & $\mathrm{NC}$ & $\mathrm{NC}$ & $\mathrm{NC}$ & $\mathrm{NC}$ & $\mathrm{NC}$ & $\mathrm{NC}$ \\
\hline GA & $\mathrm{NC}$ & $\mathrm{NC}$ & $\mathrm{NC}$ & $\mathrm{NC}$ & $\mathrm{NC}$ & $\mathrm{NC}$ & $\mathrm{NC}$ & $\mathrm{NC}$ \\
\hline GD & $\mathrm{NC}$ & $\mathrm{NC}$ & $\mathrm{NC}$ & $\mathrm{NC}$ & $\mathrm{NC}$ & $\mathrm{NC}$ & $\mathrm{NC}$ & $\mathrm{NC}$ \\
\hline $\mathrm{L}$ & $\mathrm{NC}$ & $\mathrm{NC}$ & $\mathrm{NC}$ & $\mathrm{NC}$ & $\mathrm{NC}$ & $\mathrm{NC}$ & $\mathrm{NC}$ & $\mathrm{NC}$ \\
\hline \multicolumn{9}{|c|}{ Selected 1999 HBESL $(\mathrm{mg} / \mathrm{kg})$} \\
\hline HD & 0.55 & 14 & 0.01 & 0.3 & NA & NA & 0.016 & NA \\
\hline VX & 0.047 & 1.2 & 0.042 & 1.1 & 0.047 & NA & NA & NA \\
\hline GB & 1.6 & 41 & 1.3 & 32 & NA & NA & 0.53 & NA \\
\hline GA & 3.1 & 82 & 2.8 & 68 & NA & NA & 0.8 & NA \\
\hline GD & 0.31 & 8.2 & 0.22 & 5.2 & NA & NA & 0.18 & NA \\
\hline $\mathrm{L}$ & 7.8 & $7.8^{d}$ & 0.3 & 3.7 & 7.8 & NA & NA & NA \\
\hline
\end{tabular}

${ }^{a}$ Because the potential for migration to groundwater is quite low, it is recommended that a site-specific analysis of this SSL (soil screening level) be conducted only for those situations where groundwater contamination is a concern.

$\mathrm{PRG}=$ preliminary remediation goal; $\mathrm{RBC}=$ risk-based concentration.

${ }^{b}$ Volatilization factor not available.

${ }^{\mathrm{c}} \mathrm{SSL}$ cannot be calculated because a $\mathrm{K}_{\mathrm{ow}}$ is not available.

${ }^{d} \mathrm{RBC}$ (risk-based concentration) value derived for the industrial worker scenario was potentially above acute toxicity levels; therefore, the upper bound value of the residential scenario is suggested as a substitute.

$\mathrm{NC}=$ No cancer SFs.

$\mathrm{NA}=$ Not applicable. 

Appendix B

FIELD DRINKING WATER CRITERIA AND AIR EXPOSURE GUIDELINE LEVELS 



\section{Appendix B}

\section{FIELD DRINKING WATER CRITERIA AND AIR EXPOSURE GUIDELINE LEVELS}

This table is taken from Table B.2 of DA (2005a; Sanitary Control and Surveillance of Field Water Supplies, TB MED 577, Headquarters, Department of the Army, December 2005).

Table B.1. DOD and international military potable field water quality standards

\begin{tabular}{|c|c|c|c|c|c|c|c|c|}
\hline \multirow{3}{*}{$\begin{array}{c}\text { Duration } \\
\text { Standard } \\
\begin{array}{c}\text { Consumption } \\
\text { rate }\end{array} \\
\end{array}$} & \multicolumn{4}{|c|}{ Short-term: for use less than $7 \mathrm{~d}$} & \multicolumn{4}{|c|}{ Long-term: for use more than $7 \mathrm{~d}$} \\
\hline & \multirow{2}{*}{$\begin{array}{c}\text { QSTAG } \\
245 \\
5 \mathrm{~L} / \mathrm{d}\end{array}$} & \multirow{2}{*}{$\begin{array}{c}\text { STANAG } \\
2136 \\
5 \text { L/d }\end{array}$} & \multicolumn{2}{|c|}{$\begin{array}{c}\text { DOD tri-service } \\
\text { standards }\end{array}$} & \multirow{2}{*}{$\begin{array}{c}\text { QSTAG } \\
245 \\
5 \mathrm{~L} / \mathrm{d}\end{array}$} & \multirow{2}{*}{$\begin{array}{c}\text { STANAG } \\
2136 \\
5 \mathrm{~L} / \mathrm{d}\end{array}$} & \multicolumn{2}{|c|}{$\begin{array}{c}\text { DOD tri-service } \\
\text { standards }\end{array}$} \\
\hline & & & $5 \mathrm{~L} / \mathrm{d}$ & $15 \mathrm{~L} / \mathrm{d}$ & & & $5 \mathrm{~L} / \mathrm{d}$ & $15 \mathrm{~L} / \mathrm{d}$ \\
\hline \multicolumn{9}{|c|}{ Chemical warfare agents } \\
\hline $\begin{array}{l}\text { Lewisite } \\
\text { (arsenic } \\
\text { fraction) }\end{array}$ & - & 80 & 80 & 27 & - & - & - & - \\
\hline $\begin{array}{l}\text { Sulfur mustard } \\
(\mu \mathrm{g} / \mathrm{L})\end{array}$ & 200 & 140 & 140 & 47 & 50 & - & - & - \\
\hline $\begin{array}{l}\text { Nerve agents }^{a} \\
(\mu \mathrm{g} / \mathrm{L})\end{array}$ & - & 12 & 12 & 4 & 5 & - & - & - \\
\hline $\mathrm{GA}^{b}(\mu \mathrm{g} / \mathrm{L})$ & - & - & 140 & 46 & - & - & - & - \\
\hline $\mathrm{GB}^{b}(\mu \mathrm{g} / \mathrm{L})$ & - & - & 28 & 9.3 & - & - & - & - \\
\hline $\mathrm{GD}^{b}(\mu \mathrm{g} / \mathrm{L})$ & - & - & 12 & 4 & - & - & - & - \\
\hline $\mathrm{VX}^{b}(\mu \mathrm{g} / \mathrm{L})$ & - & - & 15 & 5 & - & - & - & - \\
\hline
\end{tabular}

$\mu \mathrm{g} / \mathrm{L}=$ microgram per liter

${ }^{a}$ Interim standards are based on GD because the current test method is nonspecific for the different organophosphate (OP) nerve agents, and GD has the lowest standard.

${ }^{b}$ These are goal values for individual OP nerve agents. They will become the standards when field tests capable of analyzing water for the specific agents and concentrations become available.

QSTAG = Quadripartite (American-British-Canadian-Australian Armies) Standardization Agreement

STANAG $=$ Standardization Agreement $($ NATO $)$ 
Table B.2. Comparison of chemical warfare Acute Exposure Guideline Levels (AEGLs) with other existing guidelines

\begin{tabular}{|c|c|c|c|c|c|c|c|c|c|}
\hline \multirow[b]{2}{*}{ Agent } & \multirow[b]{2}{*}{$\begin{array}{l}\text { Type of } \\
\text { value }\end{array}$} & \multicolumn{6}{|c|}{ Acute exposures } & \multicolumn{2}{|c|}{$\begin{array}{c}\text { Repeated, chronic } \\
\text { exposures }\end{array}$} \\
\hline & & $\begin{array}{c}\mathrm{Ct}^{a} \\
\text { (no set time) } \\
\left(\text { mg-min } / \mathbf{m}^{3}\right)\end{array}$ & $\begin{array}{l}10 \mathrm{~min} \\
\left(\mathrm{mg} / \mathrm{m}^{3}\right)\end{array}$ & $\begin{array}{l}30 \mathrm{~min} \\
\left(\mathrm{mg} / \mathrm{m}^{3}\right)\end{array}$ & $\begin{array}{c}1 \mathbf{h} \\
\left(\mathbf{m g} / \mathbf{m}^{3}\right)\end{array}$ & $\begin{array}{c}4 \mathbf{h} \\
\left(\mathrm{mg} / \mathrm{m}^{3}\right)\end{array}$ & $\begin{array}{c}\mathbf{8 ~ h} \\
\left(\mathbf{m g} / \mathbf{m}^{3}\right)\end{array}$ & $\begin{array}{c}\mathbf{8 h} \\
\left(\mathrm{mg} / \mathrm{m}^{3}\right)\end{array}$ & $\begin{array}{c}24 \mathrm{~h} \\
\left(\mathrm{mg} / \mathrm{m}^{3}\right)\end{array}$ \\
\hline GB & AEGL-1 ${ }^{b}$ & & 0.0069 & 0.0040 & 0.0028 & 0.0014 & 0.0010 & & \\
\hline GB & $\mathrm{AEGL}^{b}{ }^{b}$ & & 0.087 & 0.050 & 0.035 & 0.017 & 0.013 & & \\
\hline GB & AEGL-3 ${ }^{b}$ & & 0.38 & 0.19 & 0.13 & 0.070 & 0.051 & & \\
\hline GB & IDLH $^{c, d}$ & & & 0.1 & & & & & \\
\hline GB & TWA $^{d}$ & & & & & & & 0.00003 & 0.000001 \\
\hline GB & $\mathrm{ATEL}^{e}$ & 0.5 & & & & & & & \\
\hline GA & AEGL-1 ${ }^{b}$ & & 0.0069 & 0.0040 & 0.0028 & 0.0014 & 0.0010 & & \\
\hline GA & AEGL-2 ${ }^{b}$ & & 0.087 & 0.050 & 0.035 & 0.017 & 0.013 & & \\
\hline GA & AEGL-3 $^{b}$ & & 0.76 & 0.38 & 0.26 & 0.14 & 0.10 & & \\
\hline GA & IDLH $^{c, d}$ & & & 0.1 & & & & & \\
\hline GA & TWA $^{d}$ & & & & & & & 0.00003 & 0.000001 \\
\hline GD & AEGL-1 ${ }^{b}$ & & 0.0035 & 0.0020 & 0.0014 & 0.00070 & 0.00050 & & \\
\hline GD & AEGL-2 $^{b}$ & & 0.044 & 0.025 & 0.018 & 0.0085 & 0.0065 & & \\
\hline GD & AEGL-3 $^{b}$ & & 0.38 & 0.19 & 0.13 & 0.070 & 0.051 & & \\
\hline GD & IDLH $^{c}$ & & & 0.05 & & & & & \\
\hline GD & TWA $^{c}$ & & & & & & & 0.00003 & 0.000001 \\
\hline GF & AEGL-1 $^{b}$ & & 0.0035 & 0.0020 & 0.0014 & 0.00070 & 0.00050 & & \\
\hline GF & AEGL-2 ${ }^{b}$ & & 0.044 & 0.025 & 0.018 & 0.0085 & 0.0065 & & \\
\hline GF & AEGL-3 ${ }^{b}$ & & 0.38 & 0.19 & 0.13 & 0.070 & 0.051 & & \\
\hline GF & IDLH $^{c}$ & & & 0.05 & & & & & \\
\hline GF & TWA $^{c}$ & & & & & & & 0.00003 & 0.000001 \\
\hline HD & AEGL-1 ${ }^{b}$ & & 0.40 & 0.13 & 0.067 & 0.017 & 0.008 & & \\
\hline HD & AEGL-2 $2^{b}$ & & 0.60 & 0.20 & 0.10 & 0.025 & 0.013 & & \\
\hline HD & AEGL-3 ${ }^{b}$ & & 3.9 & 2.7 & 2.1 & 0.53 & 0.27 & & \\
\hline HD & $\mathrm{IDLH}^{c, d}$ & & & 0.7 & & & & & \\
\hline HD & $\mathrm{TWA}^{c, d}$ & & & & & & & 0.0004 & 0.00002 \\
\hline
\end{tabular}


Table B.2. (continued)

\begin{tabular}{|c|c|c|c|c|c|c|c|c|c|}
\hline \multirow[b]{2}{*}{ Agent } & \multirow[b]{2}{*}{$\begin{array}{l}\text { Type of } \\
\text { value }\end{array}$} & \multicolumn{6}{|c|}{ Acute exposures } & \multicolumn{2}{|c|}{$\begin{array}{c}\text { Repeated, chronic } \\
\text { exposures }\end{array}$} \\
\hline & & $\begin{array}{c}\mathrm{Ct}^{a} \\
(\text { no set time) } \\
\left(\mathbf{m g}-\mathrm{min} / \mathrm{m}^{3}\right)\end{array}$ & $\underset{\left(\mathrm{mg} / \mathrm{m}^{3}\right)}{10 \mathrm{~min}}$ & $\underset{\left(\mathrm{mg} / \mathrm{m}^{3}\right)}{30 \mathrm{~min}}$ & $\begin{array}{c}1 \mathrm{~h} \\
\left(\mathrm{mg} / \mathrm{m}^{3}\right)\end{array}$ & $\begin{array}{c}4 \mathrm{~h} \\
\left(\mathrm{mg} / \mathrm{m}^{3}\right)\end{array}$ & $\begin{array}{c}\mathbf{8 ~ h} \\
\left(\mathbf{m g} / \mathbf{m}^{3}\right)\end{array}$ & $\begin{array}{c}\mathbf{8 ~ h} \\
\left(\mathbf{m g} / \mathbf{m}^{3}\right)\end{array}$ & $\underset{\left(\mathrm{mg} / \mathrm{m}^{3}\right)}{24 \mathrm{~h}}$ \\
\hline HD & ATEL $^{e}$ & 2.0 & & & & & & & \\
\hline $\mathrm{VX}$ & AEGL-1 $^{b}$ & & 0.00057 & 0.00033 & 0.00017 & 0.00010 & 0.000071 & & \\
\hline VX & AEGL-2 ${ }^{b}$ & & 0.0072 & 0.0042 & 0.0029 & 0.0015 & 0.0010 & & \\
\hline VX & AEGL-3 ${ }^{b}$ & & 0.029 & 0.015 & 0.010 & 0.0052 & 0.0038 & & \\
\hline $\mathrm{VX}$ & $\mathrm{IDLH}^{c, d}$ & & & 0.003 & & & & & \\
\hline $\mathrm{VX}$ & TWA $^{d}$ & & & & & & & 0.000001 & 0.0000006 \\
\hline VX & $\mathrm{ATEL}^{e}$ & 0.4 & & & & & & & \\
\hline
\end{tabular}

${ }^{a}$ Concentration $\times$ exposure time (in this case applied as a simple linear equation).

${ }^{b}$ Percutaneous absorption of G agent or agent VX vapors is known to be an effective route of exposure; nevertheless, percutaneous exposure vapor concentrations needed to produce similar adverse effects are greater than inhalation vapor concentrations by several orders of magnitude. Thus, the AEGL values presented are considered protective for both inhalation and percutaneous routes of exposure (NRC 2003).

${ }^{\circ} \mathrm{DA}(2004)$.

${ }^{d}$ DHHS (2003) for nerve agents and DHHS (2004) for sulfur mustard agent HD; 8-h value is TWA for repeated chronic occupational exposure; 24-h value is TWA for the repeated general population exposure ( $7 \mathrm{~d} /$ week for multiple years).

${ }^{e}$ Acute threshold effects level; Thacker (1994). [Note: Ct values derived originally for military casualty estimation were approved by DHHS in 1994 for civilian emergency planning at U.S. Army chemical stockpile sites, but have since been superseded by the Army and FEMA with AEGLs (CSEPP 2003). 

Appendix C AGENT AND DEGRADATION PRODUCT PHYSICAL, CHEMICAL, AND ENVIRONMENTAL PARAMETERS 

Table C.1. Physical, chemical, and environmental properties of chemical warfare agents ${ }^{a}$

\begin{tabular}{|c|c|c|c|c|c|c|c|}
\hline Property & HD & $\mathbf{L}$ & GA & GB & GD & GF & VX \\
\hline $\begin{array}{l}\text { Primary } \\
\text { exposure } \\
\text { pathway } \\
\end{array}$ & Vapor/contact & Vapor/contact & Vapor/contact & Vapor & Vapor & Vapor & Contact \\
\hline Physical state & Liquid & Liquid & Liquid & Liquid & Liquid & Liquid & Liquid \\
\hline $\begin{array}{l}\text { Molecular } \\
\text { weight }\end{array}$ & 159.08 & 207.32 & 162.1 & 140.1 & 182.2 & 180.16 & 267.4 \\
\hline Boiling point & 227.8 & 196 (est.) & 245 & 158 & 198 & 228 (est.) & 298 \\
\hline $\begin{array}{l}\text { Vapor pressure } \\
\text { (mm Hg at } \\
25 \mathrm{C} \text { ) }\end{array}$ & $\begin{array}{l}0.07 \text { at } 20 \mathrm{C} \\
0.165^{b}\end{array}$ & $\begin{array}{l}0.35 \\
0.58^{b} \\
0.40 \text { (trans) } \\
1.56 \text { (cis) } \\
\end{array}$ & 0.037 & $2.10^{b}$ & 0.40 & $\begin{array}{l}0.0927,0.0098 \text { at } \\
0 \text { C }\end{array}$ & 0.0007 \\
\hline $\begin{array}{l}\text { Water } \\
\text { solubility } \\
\text { (g/L) }\end{array}$ & $\begin{array}{l}\text { Sparingly sol. } \\
\text { in water } \\
(<1 \%)-0.8^{b}\end{array}$ & $0.5^{c}$ & $\begin{array}{l}98(25 \mathrm{C}) \\
72(20 \mathrm{C}) \\
50-100^{b}\end{array}$ & Miscible $^{b}$ & $\begin{array}{l}21(20 \mathrm{C}) \\
20-30^{b}\end{array}$ & $\begin{array}{l}3.7 \mathrm{~g} / 100 \mathrm{~g} \text { at } \\
25 \mathrm{C} ; 5.1 \mathrm{~g} / \\
100 \mathrm{~g} \text { at } 0 \mathrm{C}\end{array}$ & $\begin{array}{l}30 ; 30 \mathrm{~g} / 100 \mathrm{~g} \text { at } \\
25 \mathrm{C} ; 7.5 \mathrm{~g} / \\
100 \mathrm{~g} \text { at } 15 \mathrm{C} ; \\
10-50^{b}\end{array}$ \\
\hline $\begin{array}{l}\text { Liquid density } \\
(\mathrm{g} / \mathrm{ml} \text { at } 25 \mathrm{C})\end{array}$ & 1.27 & 1.88 & 1.07 & 1.10 & 1.02 & $\begin{array}{l}1.13 ; 1.53 \text { at } 0 \mathrm{C} \\
\text { (est.) }\end{array}$ & 1.006 \\
\hline $\begin{array}{l}\text { log octanol- } \\
\text { water } \\
\text { partition } \\
\text { coefficient } \\
\left(\mathrm{K}_{\mathrm{ow}}\right)\end{array}$ & $1.37^{d}$ & $\mathrm{NA}^{e}$ & $1.18^{f}$ & $0.15^{f}$ & $1.02^{f}$ & NA & $2.09^{d}$ \\
\hline $\log K_{\text {ow }}$ & $1.37^{d}$ & $\mathrm{NA}^{h}$ & $0.384^{f}$ & $0.299^{f}$ & $1.82^{f}$ & NA & $2.09^{d}$ \\
\hline $\begin{array}{l}\text { Hydrolysis } \\
\text { half-life (h) }\end{array}$ & $\begin{array}{l}0.08 \text { (acidic); } \\
1 \text { (in salt water; } \\
0.065-0.26^{d}\end{array}$ & "Rapid" & $\begin{array}{l}2(\mathrm{pH} \mathrm{9})^{b} \\
8.5(\mathrm{pH} 7) ; \\
0.9(\mathrm{pH} \mathrm{10}) \\
3.5(\mathrm{pH} \mathrm{2)} ; \\
2.5(\mathrm{pH} 5)^{b}\end{array}$ & $\begin{array}{l}3.5(\mathrm{pH} 2) ; \\
80(\mathrm{pH} 7)^{b} \\
47(\mathrm{pH} \mathrm{6}) ; \\
0.9(\mathrm{pH} \mathrm{10})^{b}\end{array}$ & $\begin{array}{l}60(\mathrm{pH} \mathrm{10);} \\
45(\mathrm{pH} \mathrm{6.65)} \\
3(\mathrm{pH} \mathrm{2)}\end{array}$ & $\begin{array}{l}42 \text { ( } 25 \mathrm{C} \text { in } \\
\text { distilled water) }\end{array}$ & $\begin{array}{l}\sim 50(\mathrm{pH} 9)^{b} \\
57^{g} \\
80^{h} \\
1000(\mathrm{pH} 7)^{b} \\
2000(\mathrm{pH})^{b} ; \\
\quad 60 \text { (pure water) }\end{array}$ \\
\hline $\begin{array}{l}\text { Persistence in } \\
\text { soil }\end{array}$ & $\begin{array}{l}\text { Several weeks }{ }^{d} \\
+1 \text { year }^{i}\end{array}$ & $\begin{array}{l}\text { L hydrolyzes rapidly } \\
\text { (“instantaneously"); } \\
\text { in bulk, polymeric } \\
\text { coating of } \\
\text { hydrolysis products } \\
\text { may form persistent } \\
\text { capsules }^{i}\end{array}$ & 1 to $1.5 \mathrm{~d}$ & $\begin{array}{l}2.5 \mathrm{~h} \text { to } 5 \mathrm{~d} \\
<1 \text { month }^{i}\end{array}$ & 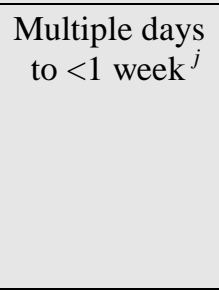 & $\begin{array}{l}\text { Considered } \\
\text { somewhat more } \\
\text { persistent than } \\
\text { GD }\end{array}$ & $\begin{array}{l}2 \text { to } 6 \mathrm{~d} \\
<3 \text { months }\end{array}$ \\
\hline
\end{tabular}


Table C.1. (continued)

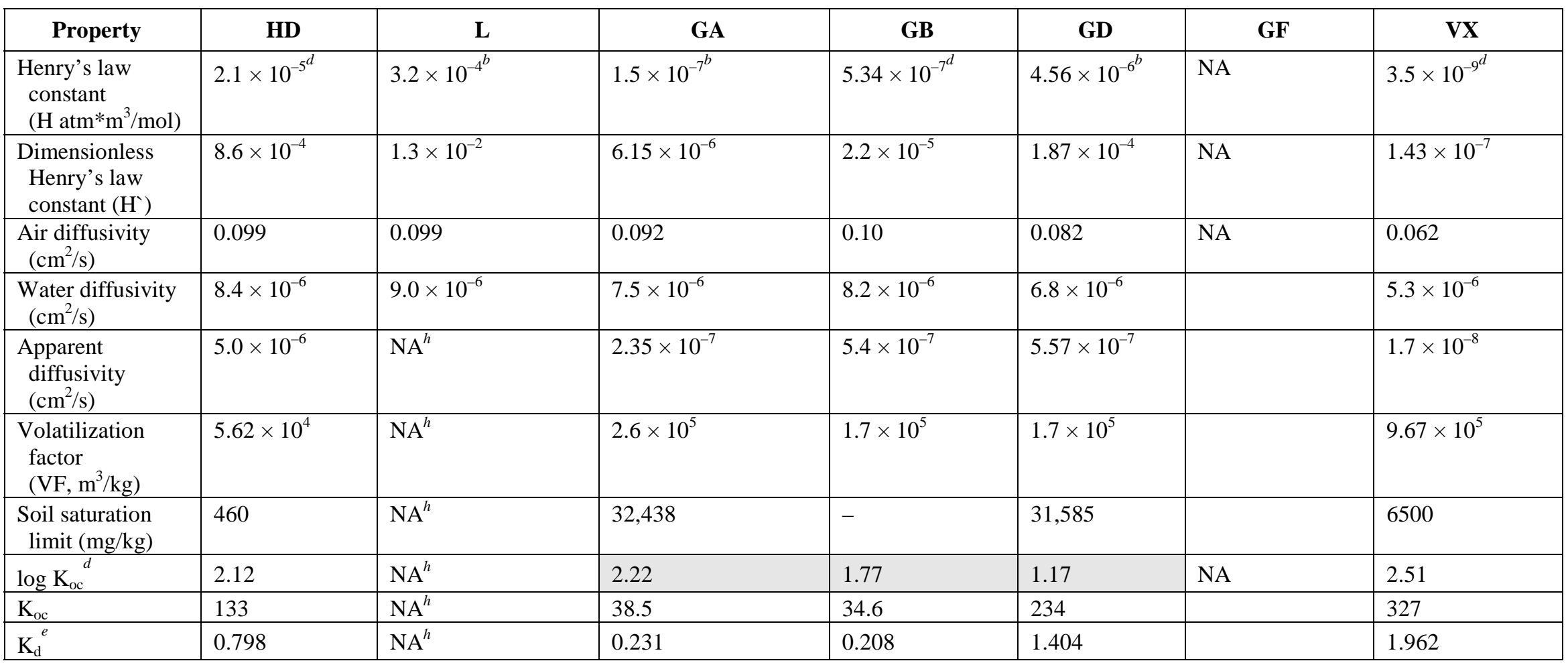

Note: Fields with updated entries from USACHPPM (1999) are highlighted. Updated entries are largely obtained from DA (2005b) and NRC (2003). Persistence is dependent upon temperature, moisture, $\mathrm{pH}$ and organic content of soils, UV exposure, etc.

Sources: Principal summary sources are DA (2005, 1974), NRC (2003), and Munro et al. (1999) unless otherwise noted.

${ }^{a} \mathrm{HD}\left(\mathrm{C}_{4} \mathrm{H}_{8} \mathrm{Cl}_{2} \mathrm{~S}\right.$; CAS \# 505-60-2); L $\left(\mathrm{C}_{2} \mathrm{H}_{2} \mathrm{AsCl}_{3}\right.$, CAS \# 541-25-3); GA $\left(\mathrm{C}_{5} \mathrm{H}_{11} \mathrm{~N}_{2} \mathrm{O}_{2} \mathrm{P}\right.$, CAS \# 77-81-6); GB $\left(\mathrm{C}_{4} \mathrm{H}_{10} \mathrm{FO} \mathrm{O}_{2} \mathrm{P}, \mathrm{CAS}\right.$ \# 107-44-8); GD $\left(\mathrm{C}_{7} \mathrm{H}_{16} \mathrm{FO} \mathrm{P}_{2} \mathrm{P}, \mathrm{CAS}\right.$ \# 96-64-0; GF $\left(\mathrm{C}_{7} \mathrm{H}_{14} \mathrm{FO}_{2} \mathrm{P}\right.$, CAS \# 329-99-7); $\mathrm{VX}\left(\mathrm{C}_{11} \mathrm{H}_{26} \mathrm{NO}_{2} \mathrm{PS}\right.$, CAS \# 50782-69-9)

${ }^{b}$ Value from MacNaughton and Brewer (1994); hydrolysis of HD limited by rates of dissolution.

${ }^{c}$ According to Rosenblatt et al. (1975), solubility data for Lewisite are meaningless because of very rapid hydrolysis to Lewisite oxide (solid). Please note that Lewisite decomposes prior to boiling.

${ }^{d}$ Values from Small (1984); hydrolysis half-lives at $20-25^{\circ} \mathrm{C}$; soil persistence for agent applied to soil surface.

${ }^{e}$ Not available; cannot be calculated due to rapid hydrolysis.

${ }^{f}$ Estimated value from Britton and Grant (1988).

${ }^{g}$ Value from Szafraniec et al. (1990); unbuffered water; when dissolved, VX causes an initial increase in pH to 9 which dissolves slowly in water.

${ }^{h}$ Value from Yang et al. (1990); spontaneous hydrolysis.

${ }^{i}$ Value from Rosenblatt et al. (1995); for worst plausible conditions.

${ }^{j}$ From Buswell et al. (1944), USAF (2003), Murdock et al. (2004), McGuire et al. (1993). 
Table C.2. Some physical properties of selected chemical warfare agent degradation products ${ }^{a}$

\begin{tabular}{|c|c|c|c|c|c|c|}
\hline $\begin{array}{c}\text { Parent } \\
\text { agent }\end{array}$ & Degradation product & $\begin{array}{l}\text { Water solubility } \\
\quad(\mathrm{mg} / \mathrm{L})\end{array}$ & $\log K_{\text {ow }}$ & $\log K_{o c}$ & pK $\left(25^{\circ} \mathrm{C}\right)$ & $\begin{array}{l}\text { Vapor pressure } \\
\quad(\mathbf{m m ~ H g})\end{array}$ \\
\hline $\mathrm{HD}$ & Thiodigylcol (CAS 111-48-8) & Miscible; soluble & $-0.77,-0.62^{b}$ & 0.96 & NA & 0.00002 \\
\hline Lewisite & Lewisite oxide (CAS 3088-37-7) & $1.2 \%^{c}$ & NA & NA & NA & NA \\
\hline GB & $\begin{array}{l}\text { Isopropyl methylphosphonic acid } \\
\text { (IMPA) (CAS 1832-54-8) }\end{array}$ & $4.8 \times 10^{4}$ & -0.54 & 1.08 & NA & $3.4 \times 10^{-3}$ \\
\hline $\begin{array}{l}\text { VX, GB; } \\
\text { GD }\end{array}$ & $\begin{array}{l}\text { Methylphosphonic acid (MPA) } \\
\text { (CAS 993-13-5) }\end{array}$ & $>1.0 \times 10^{6}$ & -2.28 & 0.15 & 2.38 & $2 \times 10^{-6^{d}}$ \\
\hline VX & $\begin{array}{l}\text { Ethyl methylphosphonic acid (EMPA) } \\
\text { (CAS 1832-53-7) }\end{array}$ & $1.8 \times 10^{5}$ & -1.15 & 0.75 & $2.00,2.76^{e}$ & $3.6 \times 10^{-4}$ \\
\hline$\overline{V X}$ & $\begin{array}{l}S \text {-(2-Diisopropylaminoethyl) } \\
\text { methylphosphonothioic acid } \\
\text { (EA-2192) (CAS 73207-98-4) }\end{array}$ & Infinitely soluble & 0.96 & 1.90 & 11.05 & NA \\
\hline
\end{tabular}

$\mathrm{NA}=$ Not available.

${ }^{a}$ From Small (1984) except where otherwise indicated.

${ }^{b}$ Reddy et al. (2005).

${ }^{c}$ Buswell et al. (1944).

${ }^{d}$ Howard and Meylan (1997).

${ }^{e}$ Bossle et al. (1983). 

Appendix D

LAND USE EQUATIONS AND EXPOSURE PARAMETERS 

Appendix D

LAND USE EQUATIONS AND EXPOSURE PARAMETERS

USACHPPM (1999) presented HBESLs for three EPA organizations that reflected regional and programmatic differences. By 2006, the EPA has moved toward a single "national" screening table approach, similar to the EPA Region IX PRG model, in an attempt to unify the risk model differences between various EPA regions (notably Regions III, VI, and IX). The three regional tables contained differences in selection of toxicity values, inclusion of various chemicals, route-to-route extrapolation, and update frequency. It is the goal of the EPA's National Screening Table Working Group to resolve these differences and provide updates as new toxicity information becomes available. The EPA's Office of Superfund, however, presents slightly different PRG equations within different portions of the Assessment and Remediation Division. The radionuclide PRGs use an "inhalation expression" in their PRG equations while the chemical compound PRGs do not. The inhalation expression, as used in the radionuclide PRGs, divides the time a receptor spends outdoors vs indoors and applies an indoor air dilution factor to the time spent indoors.

The residential and indoor worker equations presented in this appendix are presented in a format to allow chemical PRG and Superfund radionuclide formats to be followed and provide the user flexibility to perform site-specific assessment. With the tables, values are presented for the "inhalation expression" variables that allow the equations to generate HBESLs based on either the chemical PRG or Superfund radionuclide equations.

The following equations used for screening level estimation are compilations of the most recent EPA guidance (EPA 1991c, 2000b, 2002, 2004). See the reference section in the main body for documents used. The individual exposure parameter values used in the equations are referenced in the tables (Tables D.1 through D.6) following the equations. Websites were also used and are listed below:

http://rais.ornl.gov/calc start.shtml EPA SSL (soil screening level) http://rais.ornl.gov/rad start.shtml EPA radionuclide SSL http://epa-prgs.ornl.gov/radionuclides/ EPA radionuclide PRG (preliminary remediation goal) http://epa-dccs.ornl.gov/ EPA radionuclide DCC (Dose Compliance Calculator) for ARARs http://rais.ornl.gov/ Risk Assessment Information System https://epa-sprg.ornl.gov/ Radionuclides Outdoor Surfaces PRG Calculator 
Equation 1. 2006 Resident-Soil-Carcinogenic (combination of logic and equations presented in EPA 1991c, 2000b, 2002, 2004)

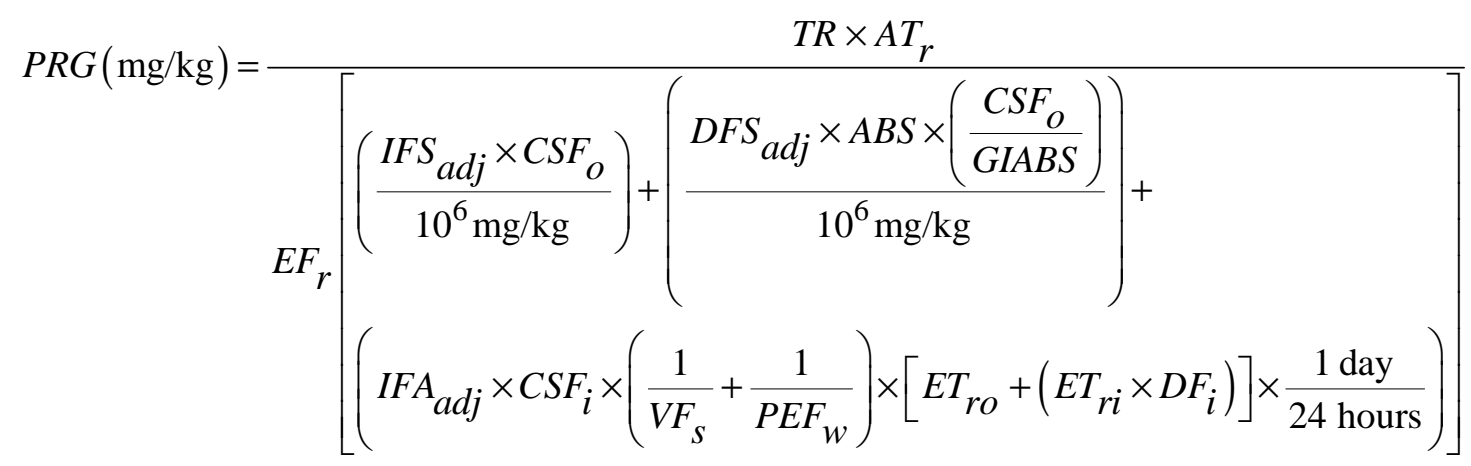

where

$$
\begin{aligned}
& I F S_{a d j}\left(\frac{\mathrm{yr} \times \mathrm{mg} / \mathrm{day}}{\mathrm{kg}}\right)=\frac{E D_{c} \times I R S_{c}}{B W_{c}}+\frac{\left(E D_{r}-E D_{c}\right) \times I R S_{a}}{B W_{a}} \\
& D F S_{a d j}\left(\frac{\mathrm{yr} \times \mathrm{mg} / \mathrm{day}}{\mathrm{kg}}\right)=\frac{E D_{c} \times A F_{c} \times S A_{c}}{B W_{c}}+\frac{\left(E D_{r}-E D_{c}\right) \times A F_{a} \times S A_{a}}{B W_{a}} \\
& I F A_{a d j}\left(\frac{\mathrm{yr} \times \mathrm{m}^{3} / \mathrm{day}}{\mathrm{kg}}\right)=\frac{E D_{c} \times I R A_{c}}{B W_{c}}+\frac{\left(E D_{r}-E D_{c}\right) \times I R A_{a}}{B W_{a}}
\end{aligned}
$$

Equation 2. 2006 Resident-Soil—Noncarcinogenic (combination of logic and equations presented in EPA 1991c, 2000b, 2002, 2004)

$$
P R G(\mathrm{mg} / \mathrm{kg})=\frac{T H Q \times B W_{c} \times A T_{r}}{E F_{r} \times E D_{c}\left[\left(\frac{1}{R f D_{o}} \times I R S_{c} \times \frac{1 \mathrm{~kg}}{10^{6} \mathrm{mg}}\right)+\right.}\left[\begin{array}{l}
\left(\frac{1}{\left(R f D_{o} \times G I A B S\right)} \times S A_{c} \times A F_{c} \times A B S \times \frac{1 \mathrm{~kg}}{10^{6} \mathrm{mg}}\right)+ \\
\left.\left(\frac{1}{R f D_{i}} \times I R A_{c} \times\left(\frac{1}{V F_{s}}+\frac{1}{P E F_{w}}\right) \times\left[E T_{r o}+\left(E T_{r i} \times D F_{i}\right)\right] \times \frac{1 \text { day }}{24 \text { hours }}\right)\right]
\end{array}\right.
$$


Table D.1. Residential soil exposure parameters

\begin{tabular}{|c|c|c|}
\hline Parameters & Value & Reference \\
\hline Target cancer risk (TR) & $10^{-5}$ & USACHPPM 1999 Sect. 1.3.2 \\
\hline Target hazard quotient (THQ) & 1 & EPA 1991 \\
\hline Body weight—adult $\left(\mathrm{BW}_{\mathrm{a}}\right)$ & $70 \mathrm{~kg}$ & EPA 2002 Exhibit 1-2 \\
\hline $\begin{array}{l}\text { Body weight-children 1-6 year old } \\
\left(\mathrm{BW}_{\mathrm{c}}\right)\end{array}$ & $15 \mathrm{~kg}$ & EPA 2002 Exhibit 1-2 \\
\hline \multirow{2}{*}{ Averaging time $-\left(\mathrm{AT}_{\mathrm{r}}\right)$} & $365 \times 70(d)$ carcinogen & \multirow[t]{2}{*}{ EPA 2002 Eq. (3-1) } \\
\hline & $\begin{array}{l}365 \times \mathrm{ED}_{\mathrm{c}}(\mathrm{d}) \text { noncarcinogen } \\
\text { child }\end{array}$ & \\
\hline Exposure frequency—residential $\left(\mathrm{EF}_{\mathrm{r}}\right)$ & $350 \mathrm{~d}$ & EPA 2002 Exhibit 1-2 \\
\hline Exposure duration—residential $\left(\mathrm{ED}_{\mathrm{r}}\right)$ & 30 years & EPA 2002 Exhibit 1-2 \\
\hline $\begin{array}{l}\text { Exposure duration-residential, child } \\
\left(\mathrm{ED}_{\mathrm{c}}\right)\end{array}$ & 6 years & EPA 2002 Exhibit 1-2 \\
\hline $\begin{array}{l}\text { Exposure time outdoor-residential } \\
\left(\mathrm{ET}_{\mathrm{ro}}\right)\end{array}$ & \begin{tabular}{|l}
0.073 unitless (Superfund \\
radionuclide PRG) \\
1.0 (Superfund chemical PRG)
\end{tabular} & EPA 2000b Sect. 2.3.1 \\
\hline Exposure time indoor-residential $\left(\mathrm{ETr}_{\mathrm{i}}\right)$ & $\begin{array}{l}0.683 \text { unitless (Superfund } \\
\text { radionuclide PRG) } \\
1.0 \text { (Superfund chemical PRG) }\end{array}$ & EPA 2000b Sect. 2.3.1 \\
\hline Indoor dilution factor- $\left(\mathrm{DF}_{\mathrm{i}}\right)$ & $\begin{array}{l}0.4 \text { unitless (Superfund } \\
\text { radionuclide PRG) } \\
1.0 \text { (Superfund chemical PRG) }\end{array}$ & EPA 2000b Sect. 2.3.1 \\
\hline Soil ingestion—adult, residential $\left(\right.$ IRS $\left._{\mathrm{a}}\right)$ & $100 \mathrm{mg} / \mathrm{d}$ & EPA 2002 Exhibit 1-2 \\
\hline Soil ingestion—child, residential $\left(\right.$ IRS $\left._{c}\right)$ & $200 \mathrm{mg} / \mathrm{d}$ & EPA 2002 Exhibit 1-2 \\
\hline Soil ingestion factor $\left(\mathrm{IFS}_{\mathrm{adj}}\right)$ & 114.3 mg-year/kg-d & EPA 1991 Eq. (3) \\
\hline Soil contact factor $\left(\right.$ SFS $\left._{\text {adj }}\right)$ & 360.8 mg-year/kg-d & EPA 2002 Eq. (3-5) \\
\hline Inhalation rate-adult $\left(\right.$ IRA $\left._{a}\right)$ & $20 \mathrm{~m}^{3} / 24-\mathrm{h} \mathrm{d}$ & EPA 2002 Exhibit 1-2 \\
\hline Inhalation rate-child $\left(\right.$ IRA $\left._{c}\right)$ & $10 \mathrm{~m}^{3} / 24-\mathrm{h} \mathrm{d}$ & EPA 1997 page 5-24 \\
\hline Inhalation factor $\left(\mathrm{IFA}_{\mathrm{adj}}\right)$ & $10.9 \mathrm{~m}^{3}$-year/kg-d & EPA 1991 Eq. (3) by analogy \\
\hline Exposed skin surface_-adult $\left(\mathrm{SA}_{\mathrm{a}}\right)$ & $5700 \mathrm{~cm}^{2} / \mathrm{d}$ & EPA 2002 Exhibit 1-2 \\
\hline Exposed skin surface-child $\left(\mathrm{SA}_{\mathrm{c}}\right)$ & $2800 \mathrm{~cm}^{2} / \mathrm{d}$ & EPA 2002 Exhibit 1-2 \\
\hline Volatilization factor for soil $\left(\mathrm{VF}_{\mathrm{s}}\right)$ & Chemical-specific $\mathrm{m}^{3} / \mathrm{kg}$ & EPA 2002 Eq. (B-11) \\
\hline $\begin{array}{l}\text { Particulate emission factor for soil } \\
\left(\mathrm{PEF}_{\mathrm{w}}\right)\end{array}$ & $1.36 \times 10^{9} \mathrm{~m}^{3} / \mathrm{kg}$ & EPA 2002 Eq. (B-8) \\
\hline Dermal absorption factor (ABS) & $\begin{array}{l}\text { HD } 0.084 \\
\text { L } 0.1 \\
\text { GA } 0.031 \\
\text { GB } 0.042 \\
\text { GD/GF } 0.094 \\
\text { VX } 0.033 \\
\end{array}$ & USACHPPM 1999 Table 2-4 \\
\hline $\begin{array}{l}\text { Gastrointestinal absorption factor- } \\
\text { (GIABS) }\end{array}$ & 0.017 (Lewisite only) & \begin{tabular}{|l} 
Derived from USACHPPM \\
1999 Table 9-2 by dividing \\
dermal RfD by oral RfD
\end{tabular} \\
\hline $\begin{array}{l}\text { Soil-to-skin adherence factor-child } \\
\left(\mathrm{AF}_{\mathrm{c}}\right)\end{array}$ & $0.2 \mathrm{mg} / \mathrm{cm}^{2}$ & EPA 2002 Exhibit 1-2 \\
\hline $\begin{array}{l}\text { Soil-to-skin adherence factor-adult } \\
\left(\mathrm{AF}_{\mathrm{a}}\right)\end{array}$ & $0.07 \mathrm{mg} / \mathrm{cm}^{2}$ & EPA 2002 Exhibit 1-2 \\
\hline
\end{tabular}


Equation 3. 2006 Indoor Worker-Soil-Carcinogenic (combination of logic and equations presented in EPA 1991c, 2000b, 2002, 2004)

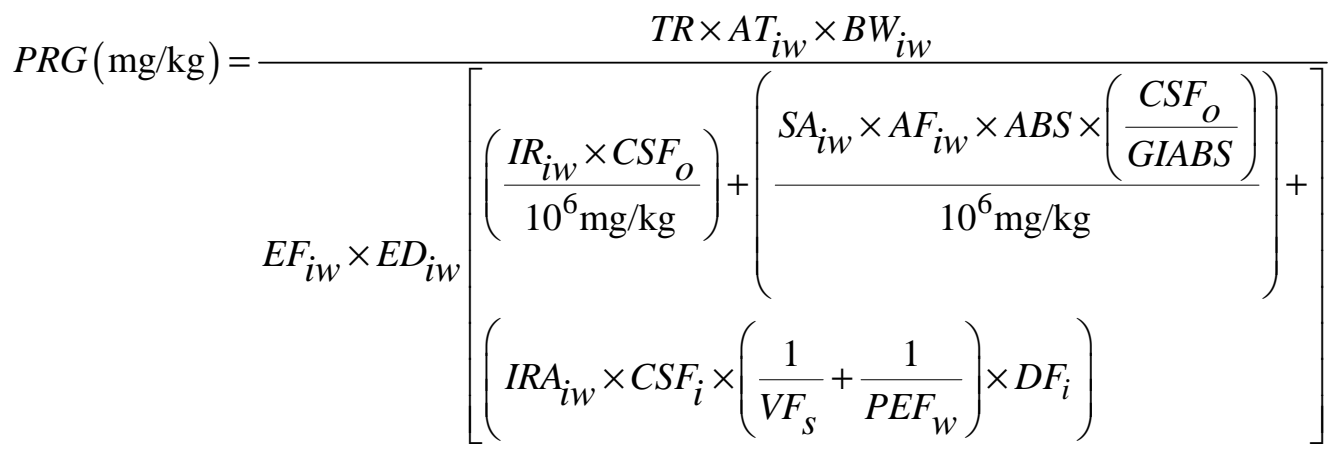

Equation 4. 2006 Indoor Worker-Soil-Noncarcinogenic (combination of logic and equations presented in EPA 1991c, 2000b, 2002, 2004)

$$
P R G(\mathrm{mg} / \mathrm{kg})=\frac{T H Q \times B W_{i w} \times A T_{i w}}{E F_{i w} \times E D_{i w}\left[\left(\frac{1}{R f D_{o}} \times I R_{i w} \times \frac{1 \mathrm{~kg}}{10^{6} \mathrm{mg}}\right)+\right.}\left(\begin{array}{l}
\left(\frac{1}{\left(R f D_{o} \times G I A B S\right)} \times S A_{i w} \times A F_{i w} \times A B S \times \frac{1 \mathrm{~kg}}{10^{6} \mathrm{mg}}\right) \\
\left(\frac{1}{R f D_{i}} \times I R A_{i w} \times\left(\frac{1}{V F_{s}}+\frac{1}{P E F_{w}}\right) \times D F_{i}\right)
\end{array}\right]
$$


Table D.2. Indoor worker soil exposure parameters

\begin{tabular}{|c|c|c|}
\hline Parameters & Value & Reference \\
\hline Target cancer risk (TR) & $10^{-4}$ & $\begin{array}{l}\text { USACHPPM } 1999 \\
\text { Sect. 1.3.2 }\end{array}$ \\
\hline Target hazard quotient (THQ) & 1 & EPA 1991 \\
\hline Body weight—indoor worker $\left(\mathrm{BW}_{\mathrm{iw}}\right)$ & $70 \mathrm{~kg}$ & EPA 2002 Exhibit 1-2 \\
\hline \multirow{2}{*}{ Averaging time- $\left(\mathrm{AT}_{\mathrm{iw}}\right)$} & $25,550 \mathrm{~d}$ carcinogen & \multirow[t]{2}{*}{ EPA 2002 Eq. (3-1) } \\
\hline & $365 \times \mathrm{ED}_{\text {iw }} \mathrm{d}$ noncarcinogen & \\
\hline $\begin{array}{l}\text { Exposure frequency-indoor worker } \\
\left(\mathrm{EF}_{\mathrm{iw}}\right)\end{array}$ & $250 \mathrm{~d}$ & EPA 2002 Exhibit 1-2 \\
\hline Exposure duration-indoor worker $\left(\mathrm{ED}_{\mathrm{iw}}\right)$ & 25 years & EPA 2002 Exhibit 1-2 \\
\hline Indoor dilution factor- $\left(\mathrm{DF}_{\mathrm{i}}\right)$ & $\begin{array}{l}\text { 0.4 (Superfund radionuclide PRG) } \\
1.0 \text { (Superfund chemical PRG) }\end{array}$ & EPA 2000b Sect. 2.3.1 \\
\hline Soil ingestion-indoor worker $\left(\right.$ IRS $\left._{\text {iw }}\right)$ & $50 \mathrm{mg} / \mathrm{d}$ & EPA 2002 Exhibit $1-2$ \\
\hline Inhalation rate-indoor worker $\left(\operatorname{IRA}_{\mathrm{iw}}\right)$ & $20 \mathrm{~m}^{3} / 8-\mathrm{h} \mathrm{d}$ & EPA 2002 Exhibit 1-2 \\
\hline $\begin{array}{l}\text { Exposed skin surface-indoor worker } \\
\left(\mathrm{SA}_{\text {iw }}\right)\end{array}$ & $0.0 \mathrm{~cm}^{2} / \mathrm{d}$ & EPA 2002 Exhibit 1-2 \\
\hline Volatilization factor for soil $\left(\mathrm{VF}_{\mathrm{s}}\right)$ & Chemical-specific $\mathrm{m}^{3} / \mathrm{kg}$ & EPA 2002 Eq. (B-11) \\
\hline Particulate emission factor for soil $\left(\mathrm{PEF}_{\mathrm{w}}\right)$ & $1.36 \times 10^{9} \mathrm{~m}^{3} / \mathrm{kg}$ & EPA 2002 Eq. (B-8) \\
\hline Dermal absorption factor (ABS) & $\begin{array}{l}\text { HD } 0.056 \\
\text { L } 0.1 \\
\text { GA } 0.021 \\
\text { GB } 0.028 \\
\text { GD/GF } 0.061 \\
\text { VX } 0.022 \\
\end{array}$ & $\begin{array}{l}\text { USACHPPM } 1999 \\
\text { Table 2-4 }\end{array}$ \\
\hline $\begin{array}{l}\text { Gastrointestinal absorption factor- } \\
\text { (GIABS) }\end{array}$ & 0.017 (Lewisite only) & $\begin{array}{l}\text { Derived from USACHPPM } \\
1999 \text { Table } 9-2 \text { by dividing } \\
\text { dermal RfD by oral RfD }\end{array}$ \\
\hline $\begin{array}{l}\text { Soil-to-skin adherence factor-indoor } \\
\text { worker }\left(\mathrm{AF}_{\mathrm{iw}}\right)\end{array}$ & $0 \mathrm{mg} / \mathrm{cm}^{2}$ & EPA 2002 Exhibit 1-2 \\
\hline
\end{tabular}


Equation 5. 2006 Outdoor Worker-Soil-Carcinogenic (combination of logic and equations presented in EPA 1991c, 2000b, 2002, 2004)

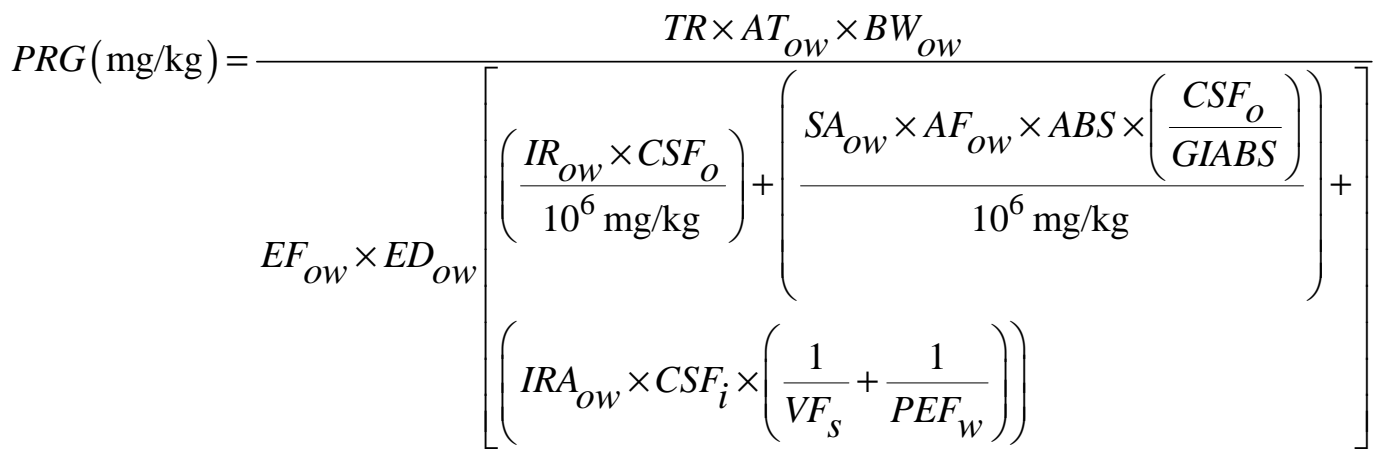

Equation 6. 2006 Outdoor Worker-Soil-Noncarcinogenic (combination of logic and equations presented in EPA 1991c, 2000b, 2002, 2004)

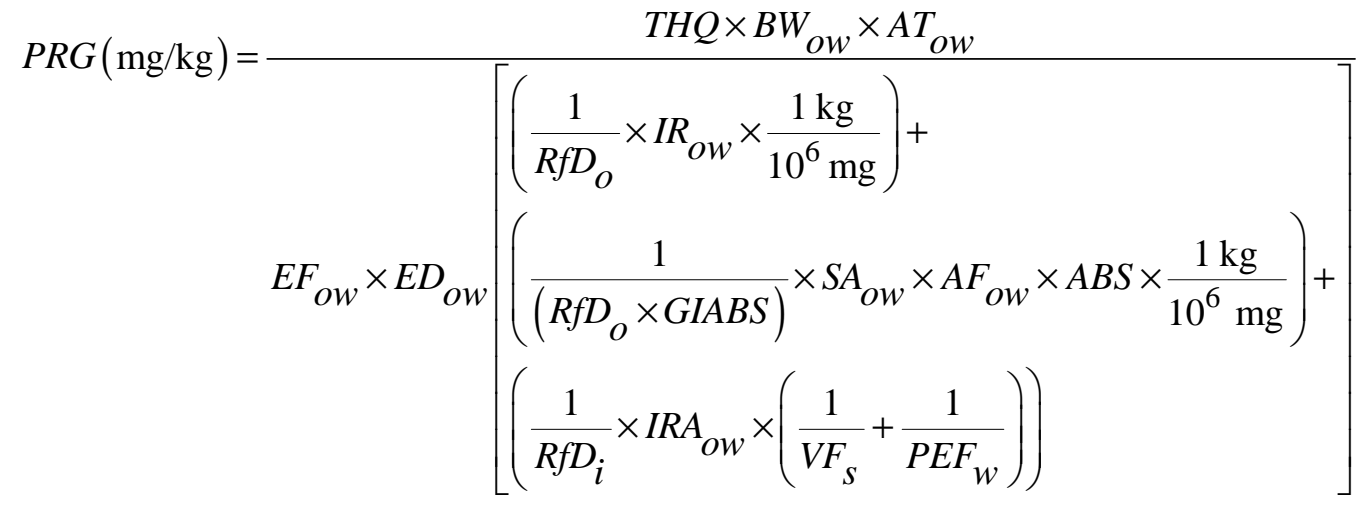


Table D.3. Outdoor worker soil exposure parameters

\begin{tabular}{|c|c|c|}
\hline Parameters & Value & Reference \\
\hline Target cancer risk (TR) & $10^{-4}$ & $\begin{array}{l}\text { USACHPPM } 1999 \\
\text { Sect. 1.3.2 }\end{array}$ \\
\hline Target hazard quotient (THQ) & 1 & EPA 1991 \\
\hline Body weight—outdoor worker $\left(\mathrm{BW}_{\mathrm{ow}}\right)$ & $70 \mathrm{~kg}$ & EPA 2002 Exhibit 1-2 \\
\hline \multirow{2}{*}{ Averaging time- $-\left(\mathrm{AT}_{\mathrm{ow}}\right)$} & $25,550 \mathrm{~d}$ carcinogen & \multirow[t]{2}{*}{ EPA 2002 Eq. (3-1) } \\
\hline & $365 \times \mathrm{ED}_{\mathrm{ow}} \mathrm{d}$ noncarcinogen & \\
\hline Exposure frequency-outdoor worker $\left(\mathrm{EF}_{\mathrm{ow}}\right)$ & $225 \mathrm{~d} /$ year & EPA 2002 Exhibit 1-2 \\
\hline Exposure duration—outdoor worker $\left(\mathrm{ED}_{\mathrm{ow}}\right)$ & 25 years & EPA 2002 Exhibit 1-2 \\
\hline Soil ingestion—outdoor worker $\left(\mathrm{IRS}_{\mathrm{ow}}\right)$ & $100 \mathrm{mg} / \mathrm{d}$ & EPA 2002 Exhibit 1-2 \\
\hline Inhalation rate—outdoor worker $\left(\mathrm{IRA}_{\mathrm{ow}}\right)$ & $20 \mathrm{~m}^{3} / 8-\mathrm{h} \mathrm{d}$ & EPA 2002 Exhibit 1-2 \\
\hline Exposed skin surface—outdoor worker $\left(\mathrm{SA}_{\mathrm{ow}}\right)$ & $3300 \mathrm{~cm}^{2} / \mathrm{d}$ & EPA 2002 Exhibit 1-2 \\
\hline Volatilization factor for soil $\left(\mathrm{VF}_{\mathrm{s}}\right)$ & Chemical-specific $\mathrm{m}^{3} / \mathrm{kg}$ & EPA 2002 Eq. (B-11) \\
\hline Particulate emission factor for soil $\left(\mathrm{PEF}_{\mathrm{w}}\right)$ & $1.36 \times 10^{9} \mathrm{~m}^{3} / \mathrm{kg}$ & EPA 2002 Eq. (B-8) \\
\hline Dermal absorption factor (ABS) & $\begin{array}{l}\text { HD } 0.056 \\
\text { L } 0.1 \\
\text { GA } 0.021 \\
\text { GB } 0.028 \\
\text { GD/GF } 0.061 \\
\text { VX } 0.022\end{array}$ & $\begin{array}{l}\text { USACHPPM } 1999 \\
\text { Table 2-4 }\end{array}$ \\
\hline Gastrointestinal absorption factor-(GIABS) & 0.017 (Lewisite only) & $\begin{array}{l}\text { Derived from } \\
\text { USACHPPM } 1999 \\
\text { Table 9-2 by dividing } \\
\text { dermal RfD by oral RfD }\end{array}$ \\
\hline $\begin{array}{l}\text { Soil-to-skin adherence factor-outdoor worker } \\
\left(\mathrm{AF}_{\mathrm{ow}}\right)\end{array}$ & $0.2 \mathrm{mg} / \mathrm{cm}^{2}$ & EPA 2002 Exhibit 1-2 \\
\hline
\end{tabular}


Equation 7. 2006 Construction Worker-Soil-Carcinogenic (combination of logic and equations presented in EPA 1991c, 2000b, 2002, 2004)

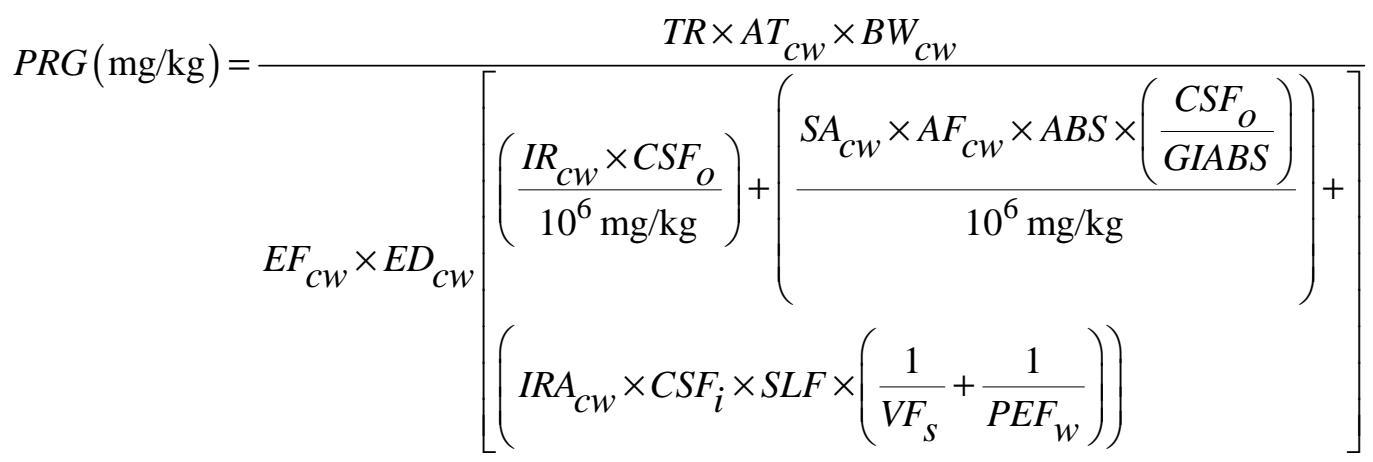

Equation 8. 2006 Construction Worker-Soil-Noncarcinogenic (combination of logic and equations presented in EPA 1991c, 2000b, 2002, 2004)

$$
P R G(\mathrm{mg} / \mathrm{kg})=\frac{T H Q \times B W_{c w} \times A T_{c w}}{E F_{c w} \times E D_{c w}\left[\left(\frac{1}{R f D_{o}} \times I R_{c w} \times \frac{1 \mathrm{~kg}}{10^{6} \mathrm{mg}}\right)+\right.}\left(\begin{array}{l}
\left(\frac{1}{\left(R f D_{o} \times G I A B S\right)} \times S A_{c w} \times A F_{c w} \times A B S \times \frac{1 \mathrm{~kg}}{10^{6} \mathrm{mg}}\right)+ \\
\left(\frac{1}{R f D_{i}} \times I R A_{c w} \times\left(\frac{1}{V F_{S}}+\frac{1}{P E F_{w}}\right) \times S L F\right)
\end{array}\right]
$$


Table D.4. Construction worker soil exposure parameters

\begin{tabular}{|c|c|c|}
\hline Parameters & Value & Reference \\
\hline Target cancer risk (TR) & $10^{-4}$ & $\begin{array}{l}\text { USACHPPM } 1999 \\
\text { Sect. 1.3.2 }\end{array}$ \\
\hline Target hazard quotient (THQ) & 1 & EPA 1991 \\
\hline Body weight—construction worker $\left(\mathrm{BW}_{\mathrm{cw}}\right)$ & $70 \mathrm{~kg}$ & EPA 2002 Exhibit 1-2 \\
\hline \multirow[t]{2}{*}{ Averaging time- $-\left(\mathrm{AT}_{\mathrm{cw}}\right)$} & $25,550 \mathrm{~d}$ carcinogen & \multirow[t]{2}{*}{ EPA 2002 Eq. (3-1) } \\
\hline & $365 \times \mathrm{ED}_{\mathrm{cw}} \mathrm{d}$ noncarcinogen & \\
\hline Exposure frequency—construction worker $\left(\mathrm{EF}_{\mathrm{cw}}\right)$ & Site-specific d/year & EPA 2002 Exhibit 1-2 \\
\hline Exposure duration-construction worker $\left(\mathrm{ED}_{\mathrm{cw}}\right)$ & Site-specific years & EPA 2002 Exhibit 1-2 \\
\hline Soil ingestion—construction worker $\left(\mathrm{IRS}_{\mathrm{cw}}\right)$ & $330 \mathrm{mg} / \mathrm{d}$ & EPA 2002 Exhibit 1-2 \\
\hline Inhalation rate-construction worker $\left(\mathrm{IRA}_{\mathrm{cw}}\right)$ & $20 \mathrm{~m}^{3} / 8-\mathrm{h} \mathrm{d}$ & EPA 2002 Exhibit 1-2 \\
\hline Exposed skin surface — construction worker $\left(\mathrm{SA}_{\mathrm{cw}}\right)$ & $3300 \mathrm{~cm}^{2} / \mathrm{d}$ & EPA 2002 Exhibit 1-2 \\
\hline Volatilization factor for soil $\left(\mathrm{VF}_{\mathrm{s}}\right)$ & Chemical-specific $\mathrm{m}^{3} / \mathrm{kg}$ & EPA 2002 Eq. (B-11) \\
\hline Particulate emission factor for soil $\left(\mathrm{PEF}_{\mathrm{w}}\right)$ & $1.36 \times 10^{9} \mathrm{~m}^{3} / \mathrm{kg}$ & EPA 2002 Eq. (B-8) \\
\hline Dermal absorption factor (ABS) & $\begin{array}{l}\text { HD } 0.056 \\
\text { L } 0.1 \\
\text { GA } 0.021 \\
\text { GB } 0.028 \\
\text { GD/GF } 0.061 \\
\text { VX } 0.022 \\
\end{array}$ & $\begin{array}{l}\text { USACHPPM } 1999 \\
\text { Table 2-4 }\end{array}$ \\
\hline Gastrointestinal absorption factor-(GIABS) & 0.017 (Lewisite only) & $\begin{array}{l}\text { Derived from USACHPPM } \\
1999 \text { Table } 9-2 \text { by dividing } \\
\text { dermal RfD by oral RfD }\end{array}$ \\
\hline $\begin{array}{l}\text { Soil-to-skin adherence factor-construction worker } \\
\left(\mathrm{AF}_{\mathrm{cw}}\right)\end{array}$ & $0.3 \mathrm{mg} / \mathrm{cm}^{2}$ & EPA 2002 Exhibit 1-2 \\
\hline
\end{tabular}


Equation 9. 2006 Trespasser-Soil-Carcinogenic (combination of logic and equations presented in EPA 1991c, 2000b, 2002, 2004)

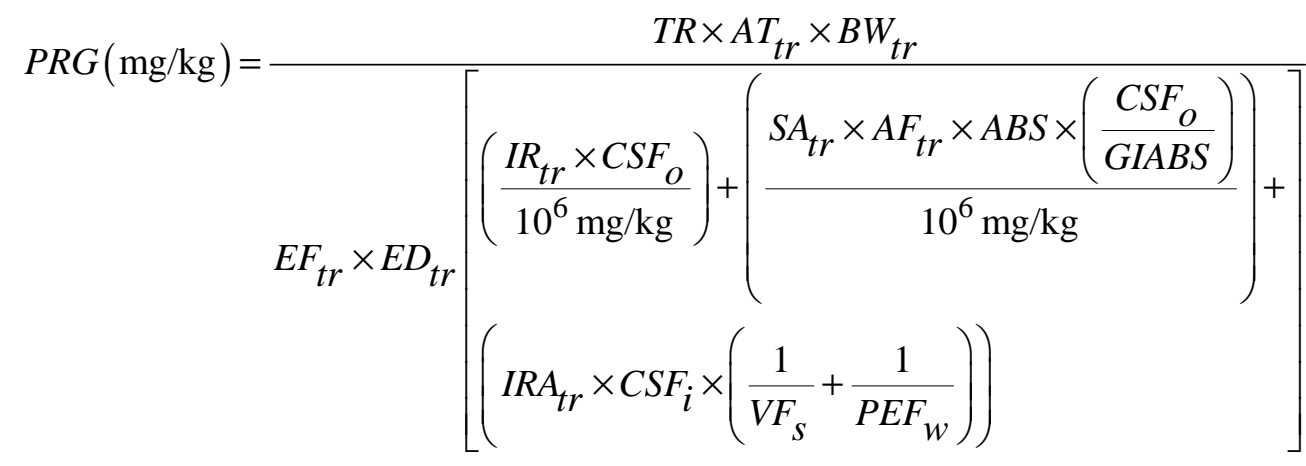

Equation 10. 2006 Trespasser-Soil-Noncarcinogenic (combination of logic and equations presented in EPA 1991c, 2000b, 2002, 2004)

$$
P R G(\mathrm{mg} / \mathrm{kg})=\frac{T H Q \times B W_{t r} \times A T_{t r}}{E F_{t r} \times E D_{t r}\left[\frac{1}{\left(\frac{1}{R f D_{o}} \times I R_{t r} \times \frac{1 \mathrm{~kg}}{10^{6} \mathrm{mg}}\right)+}\right.}\left[\begin{array}{l}
\left(\frac{1}{\left(\frac{1}{R f D_{o}} \times G I A B S\right)} \times S A_{t r} \times A F_{t r} \times A B S \times \frac{1 \mathrm{~kg}}{10^{6} \mathrm{mg}}\right)+ \\
\left.\left(\frac{1}{V F_{s}}+\frac{1}{P E F_{w}}\right)\right)
\end{array}\right]
$$


Table D.5. Trespasser soil exposure parameters

\begin{tabular}{|c|c|c|}
\hline Parameters & Value & Reference \\
\hline Target cancer risk (TR) & $10^{-6}$ & Region IV \\
\hline Target hazard quotient (THQ) & 1 & Region IV \\
\hline Body weight-trespasser $\left(\mathrm{BW}_{\mathrm{tr}}\right)$ & $45 \mathrm{~kg}$ & Region IV \\
\hline \multirow[t]{2}{*}{ Averaging time $-\left(\mathrm{AT}_{\mathrm{tr}}\right)$} & $25,550 \mathrm{~d}$ carcinogen & \multirow[t]{2}{*}{ Region IV } \\
\hline & $\begin{array}{c}365 \times \mathrm{ED}_{\mathrm{tr}} \mathrm{d} \\
\text { noncarcinogen }\end{array}$ & \\
\hline Exposure frequency - trespasser $\left(\mathrm{EF}_{\mathrm{tr}}\right)$ & $350 \mathrm{~d}$ site-specific & Region IV \\
\hline $\begin{array}{l}\text { Exposure duration- }- \text { trespasser } \\
\text { (age } 7 \text { to } 16)\left(E_{\text {tr }}\right)\end{array}$ & 10 years & Region IV \\
\hline Soil ingestion-trespasser $\left(\mathrm{IRS}_{\mathrm{tr}}\right)$ & $100 \mathrm{mg} / \mathrm{d}$ & Region IV \\
\hline Inhalation rate - trespasser $\left(\mathrm{IRA}_{\mathrm{tr}}\right)$ & $20 \mathrm{~m}^{3} / 24-\mathrm{h} \mathrm{d}$ & Region IV \\
\hline Exposed skin surface - trespasser $\left(\mathrm{SA}_{\mathrm{tr}}\right)$ & $3522 \mathrm{~cm}^{2} / \mathrm{d}$ & $\begin{array}{l}\text { RAGs Part E for face, forearms, hands } \\
\text { and lower legs }\end{array}$ \\
\hline Volatilization factor for soil $\left(\mathrm{VF}_{\mathrm{s}}\right)$ & Chemical-specific $\mathrm{m}^{3} / \mathrm{kg}$ & EPA 2002 Eq. (B-11) \\
\hline Particulate emission factor for soil $\left(\mathrm{PEF}_{\mathrm{w}}\right)$ & $1.36 \times 10^{9} \mathrm{~m}^{3} / \mathrm{kg}$ & EPA 2002 Eq. (B-8) \\
\hline Dermal absorption factor (ABS) & Chemical-specific & USACHPPM 1999 Table 2-4 \\
\hline $\begin{array}{l}\text { Gastrointestinal absorption factor- } \\
\text { (GIABS) }\end{array}$ & 0.017 (Lewisite only) & $\begin{array}{l}\text { Derived from USACHPPM } 1999 \\
\text { Table 9-2 by dividing dermal RfD by } \\
\text { oral RfD }\end{array}$ \\
\hline $\begin{array}{l}\text { Soil-to-skin adherence factor-trespasser } \\
\left(\mathrm{AF}_{\mathrm{tr}}\right)\end{array}$ & $0.2 \mathrm{mg} / \mathrm{cm}^{2}$ & Region IV \\
\hline
\end{tabular}


Equation 11. 2006 Particulate Emission Factor-Soil-Wind (combination of logic and equations presented in EPA 2002)

$$
P E F_{w}=Q / C_{w} \times \frac{3,600}{0.036 \times(1-V) \times\left(U_{m} / U_{t}\right)^{3} \times F(\chi)}
$$

where

$$
\frac{Q}{C_{w}}=A \times \exp \left[\frac{\left(\ln A_{s}-B\right)^{2}}{C}\right]
$$

Equation 12. 2006 Particulate Emission Factor-Soil-Mechanical (combination of logic and equations presented in EPA 2002)

$$
P E F_{m}=\frac{Q}{C_{m}} \times \frac{1}{F_{D}} \times \frac{T \times A_{R}}{\frac{2.6 \times(s / 12)^{0.8} \times(W / 3)^{0.4}}{\left(M_{\mathrm{dry}} / 0.2\right)^{0.3}} \times\left[\frac{(365-p)}{365}\right] \times 281.9 \times \sum V K T}
$$

where

$$
\begin{aligned}
& P E F_{m}=\text { mechanical particulate emission factor }\left(\frac{\mathrm{m}^{3}}{\mathrm{~kg}}\right) \\
& A_{R}=L_{R} \times W_{R} \times 0.092903 \mathrm{~m}^{2} / \mathrm{ft}^{2} \\
& F_{D}=0.1852+\frac{5.3537}{t_{c}}+\frac{-9.6318}{t_{c}^{2}} \\
& \frac{Q}{C_{m}}=A \times \exp \left[\frac{\left(\ln A_{s}-B\right)^{2}}{C}\right]
\end{aligned}
$$

$W($ mean vehicle weight in tons $)=\frac{\left[\left(\text { Number of cars } \times \frac{\text { tons }}{\text { car }}\right)+\left(\text { Number of trucks } \times \frac{\text { tons }}{\text { truck }}\right)\right]}{\text { Total number of vehicles }}$ Total number of vehicles

$\sum V K T($ sum of vehicle $\mathrm{km} / \mathrm{yr}$ traveled $)=$ Total number of vehicles $\times \frac{\mathrm{km}}{\text { trip }} \times \frac{\text { trips }}{\mathrm{day}} \times \frac{\text { weeks }}{\mathrm{yr}} \times \frac{\text { days }}{\text { week }}$ 
Table D.6. Particulate emission factor input parameters

\begin{tabular}{|c|c|c|}
\hline Parameters & Value & Reference \\
\hline \multicolumn{3}{|c|}{ Wind-driven particulate emission factor } \\
\hline Wind particulate emission factor- $\left(\mathrm{PEF}_{\mathrm{w}}\right)$ & $\begin{array}{l}1.36 \times 10^{9}\left(\mathrm{~m}^{3} / \mathrm{kg}\right) \text { Minneapolis- } \\
\text { specific }\end{array}$ & EPA 2002, Eq. (4-5) \\
\hline $\begin{array}{l}\text { Inverse of the mean concentration at the center of } \\
\text { a } 0.5 \text { acre square source-wind }\left(\mathrm{Q} / \mathrm{C}_{\mathrm{w}}\right)\end{array}$ & $\begin{array}{l}93.77\left(\mathrm{~g} / \mathrm{m}^{2}-\mathrm{s} \text { per } \mathrm{kg} / \mathrm{m}^{3}\right) \\
\text { Minneapolis-specific and } \mathrm{A}_{\mathrm{s}} \\
\text { specific }\end{array}$ & EPA 2002, Eq. (4-5) \\
\hline Area of site $\left(A_{s}\right)$ & 0.5 site-specific (acres) & EPA 2002, Eq. (4-5) \\
\hline Fraction of vegetative cover $(\mathrm{V})$ & 0.5 unitless & EPA 2002, Eq. (4-5) \\
\hline Mean annual wind speed $\left(\mathrm{U}_{\mathrm{m}}\right)$ & $4.69 \mathrm{~m} / \mathrm{s}$ & EPA 2002, Eq. (4-5) \\
\hline $\begin{array}{l}\text { Equivalent threshold value of wind speed at } 7 \mathrm{~m} \\
\left(\mathrm{U}_{\mathrm{t}}\right)\end{array}$ & $11.32 \mathrm{~m} / \mathrm{s}$ & EPA 2002, Eq. (4-5) \\
\hline Function dependent on $\mathrm{U}_{\mathrm{m}} / \mathrm{U}_{\mathrm{t}}[\mathrm{F}(\mathrm{x})]$ & 0.194 unitless & EPA 2002, Eq. (4-5) \\
\hline Dispersion constant (A) & PEF and region-specific unitless & $\begin{array}{l}\text { EPA 2002, Exhibit D-2 and } \\
\text { D-4 }\end{array}$ \\
\hline Dispersion constant (B) & PEF and region-specific unitless & $\begin{array}{l}\text { EPA 2002, Exhibit D-2 and } \\
\text { D-4 }\end{array}$ \\
\hline Dispersion constant $(\mathrm{C})$ & PEF and region-specific unitless & $\begin{array}{l}\text { EPA 2002, Exhibit D-2 and } \\
\text { D-4 }\end{array}$ \\
\hline \multicolumn{3}{|c|}{ Mechanically driven particulate emission factor } \\
\hline Mechanical particulate emission factor- $\left(\mathrm{PEF}_{\mathrm{m}}\right)$ & $1.12 \times 10^{5}\left(\mathrm{~m}^{3} / \mathrm{kg}\right)$ & From SPRG calculator ${ }^{a}$ \\
\hline $\begin{array}{l}\text { Inverse of the ratio of the } 1-\mathrm{h} \text { geometric mean air } \\
\text { concentration to the emission flux along a } \\
\text { straight road segment bisecting a square site- } \\
\text { mechanical }\left(\mathrm{Q} / \mathrm{C}_{\mathrm{m}}\right)\end{array}$ & $\begin{array}{l}90.54\left(\mathrm{~g} / \mathrm{m}^{2} \text {-s per } \mathrm{kg} / \mathrm{m}^{3}\right) \\
\text { Phoenix-specific and } A_{\mathrm{s}} \\
\text { specific }\end{array}$ & EPA 2002, Eq. (E-18) \\
\hline Dispersion correction factor $\left(\mathrm{F}_{\mathrm{D}}\right)$ & 0.1858 (calculated) (unitless) & EPA 2002, Eq. (E-16) \\
\hline Total time over which exposure occurs $\left(\mathrm{t}_{\mathrm{c}}\right)$ & $\begin{array}{c}t_{c}=T \text { changing units to hours } \\
262,800 \text { ( } 30 \text { years resident }) \\
219,000 \text { ( } 25 \text { years worker })\end{array}$ & EPA 2002, Eq. (E-18) \\
\hline Total time over which exposure occurs (T) & $\begin{array}{l}\mathrm{T}=\text { ED changing units to } \\
\text { seconds } \\
946,080,000 \text { ( } 30 \text { years resident }) \\
788,400,000 \text { ( } 25 \text { years worker })\end{array}$ & EPA 2002, Eq. (E-18) \\
\hline Surface area of contaminated road segment $\left(A_{R}\right)$ & $\begin{array}{l}\text { Calculated }\left(\mathrm{m}^{2}\right) \\
\mathrm{AR}=\mathrm{L}_{\mathrm{R}} \times \mathrm{W}_{\mathrm{R}} \times 0.092903 \\
\mathrm{~m}^{2} / \mathrm{ft}^{2} 274.2\end{array}$ & EPA 2002, Eq. (E-18) \\
\hline Road surface silt content (s) & $8.5 \%$ & EPA 2002, Eq. (E-18) \\
\hline Mean vehicle weight (W) & 3.2 tons & SPRG calculator $^{a}$ \\
\hline $\begin{array}{l}\text { Road surface material moisture content under } \\
\text { dry, uncontrolled conditions }\left(\mathrm{M}_{\mathrm{dry}}\right)\end{array}$ & $0.2 \%$ & EPA 2002, Eq. (E-18) \\
\hline
\end{tabular}


Table D.6. (continued)

\begin{tabular}{|c|c|c|}
\hline Parameters & Value & Reference \\
\hline $\begin{array}{l}\text { Number of days per year with at least } 0.01 \text { in. of } \\
\text { precipitation }(\mathrm{p})\end{array}$ & 150 region-specific & EPA 2002, Eq. (E-18) \\
\hline $\begin{array}{l}\text { Sum of fleet vehicle kilometers traveled during } \\
\text { the exposure duration (VKT) }\end{array}$ & $\begin{array}{l}2,8140,018(\mathrm{~km} / \text { year}) \text { (based on } \\
\text { annualized urban California } \\
\text { road and traffic data) }\end{array}$ & SPRG calculator $^{a}$ \\
\hline Length of road segment $\left(L_{R}\right)$ & $\begin{array}{l}147.6 \mathrm{ft} \\
\mathrm{LR}=\text { square root of site surface } \\
\text { contamination used for } \mathrm{A}_{\mathrm{s}}= \\
0.5 \text { acres }\end{array}$ & EPA 2002, Eq. (E-18) \\
\hline Width of road segment $\left(\mathrm{W}_{\mathrm{R}}\right)$ & $20 \mathrm{ft}$ & EPA 2002, Eq. (E-18) \\
\hline Number of cars & Site-specific & SPRG calculator ${ }^{a}$ \\
\hline Number of trucks & Site-specific & SPRG calculator $^{a}$ \\
\hline Average tons per car & Site-specific & SPRG calculator ${ }^{a}$ \\
\hline Average tons per truck & Site-specific & SPRG calculator $^{a}$ \\
\hline Total number of vehicles & Site-specific & SPRG calculator $^{a}$ \\
\hline Kilometers per trip & Calculated based on $\mathrm{A}_{\mathrm{s}}$ & SPRG calculator ${ }^{a}$ \\
\hline Trips per day & Site-specific & SPRG calculator $^{a}$ \\
\hline Weeks per year & Site-specific & SPRG calculator ${ }^{a}$ \\
\hline Days per week & Site-specific & SPRG calculator ${ }^{a}$ \\
\hline
\end{tabular}

${ }^{a}$ Please see the Radionuclides Outdoor Surfaces PRG Calculator https://epa-sprg.ornl.gov/. 


\section{Equation 13. 2006 Volatilization Factor-Soil-Wind (combination of logic and equations presented in EPA 2002)}

$$
V F=\frac{Q / C_{w} \times\left(3.14 \times D_{A} \times T\right)^{\frac{1}{2}} \times 10^{-4}\left(\mathrm{~m}^{2} / \mathrm{cm}^{2}\right)}{2 \times \rho_{b} \times D_{A}}
$$

where

$$
D_{A}=\frac{\left[\left(\theta_{a}^{10 / 3} \times H^{\prime}+\theta_{a}^{10 / 3} \times D_{W}\right) / n^{2}\right]}{\rho_{b} \times K_{d}+\theta_{w}+\theta_{a} \times H^{\prime}}
$$

\begin{tabular}{|c|c|c|}
\hline Parameters & Value & Reference \\
\hline Wind volatilization factor- $\left(\mathrm{VF}_{\mathrm{w}}\right)$ & $\left(\mathrm{m}^{3} / \mathrm{kg}\right)$ Los Angeles-specific & EPA 2002, Eq. (4-8) \\
\hline $\begin{array}{l}\text { Inverse of the geometric mean air } \\
\text { concentration to the volatilization flux at } \\
\text { center of a square source- -wind }\left(\mathrm{Q} / \mathrm{C}_{\mathrm{w}}\right)\end{array}$ & $\begin{array}{l}68.18\left(\mathrm{~g} / \mathrm{m}^{2}-\mathrm{s} \text { per } \mathrm{kg} / \mathrm{m}^{3}\right) \text { Los Angeles- } \\
\text { specific and } \mathrm{A}_{\mathrm{s}} \text { specific }\end{array}$ & EPA 2002, Eq. (4-8) \\
\hline Area of site $\left(A_{s}\right)$ & 0.5 site-specific (acres) & EPA 2002, Eq. (4-8) \\
\hline Exposure interval $(\mathrm{T})$ & $\begin{array}{l}9.5 \times 10^{08} \mathrm{~s} \\
\mathrm{~T}=\mathrm{ED} \text { changing units to seconds } \\
946,080,000(30 \text { years resident }) \\
788,400,000(25 \text { years worker })\end{array}$ & EPA 2002, Eq. (4-8) \\
\hline Fraction organic carbon in soil (foc) & $0.006 \mathrm{~g} / \mathrm{g}$ & EPA 2002, Eq. (4-8) \\
\hline Dry soil bulk density $\left(\rho_{\mathrm{b}}\right)$ & $1.5 \mathrm{~g} / \mathrm{cm}^{3}$ & EPA 2002, Eq. (4-8) \\
\hline Soil particle density $\left(\rho_{\mathrm{s}}\right)$ & $2.65 \mathrm{~g} / \mathrm{cm}^{3}$ & EPA 2002, Eq. (4-8) \\
\hline Water-filled soil porosity $\left(\Theta_{w}\right)$ & $0.15 \mathrm{~L}_{\text {water }} / \mathrm{L}_{\text {soil }}$ & EPA 2002, Eq.(4-8) \\
\hline Air-filled soil porosity $\left(\Theta_{a}\right)$ & $\mathrm{n}-\Theta_{\mathrm{w}}$ & EPA 2002, Eq. (4-8) \\
\hline Apparent diffusivity $\left(\mathrm{D}_{\mathrm{A}}\right)$ & Chemical-specific & EPA 2002, Eq. (4-8) \\
\hline Total soil porosity (Lpore/Lsoil) $\left(\Theta_{a}\right)$ & $1-\left(\rho_{\mathrm{b}} / \rho_{\mathrm{s}}\right)$ & EPA 2002, Eq. (4-8) \\
\hline Diffusivity in air $\left(\mathrm{D}_{\mathrm{i}}\right)$ & Chemical-specific $\left(\mathrm{cm}^{2} / \mathrm{s}\right)$ & Appendix C \\
\hline Diffusivity in water $\left(\mathrm{D}_{\mathrm{w}}\right)$ & Chemical-specific $\left(\mathrm{cm}^{2} / \mathrm{s}\right)$ & Appendix C \\
\hline Soil-water partition coefficient $\left(\mathrm{K}_{\mathrm{d}}\right)$ & Chemical-specific or $\mathrm{K}_{\mathrm{oc}} \times \mathrm{f}_{\mathrm{oc}}$ & EPA 2002, Eq. (4-8) \\
\hline Henry's law constant $(\mathrm{H})$ & Chemical-specific $\left(\mathrm{atm}-\mathrm{m}^{3} / \mathrm{mol}\right)$ & Appendix C \\
\hline Dimensionless Henry's law constant $\left(\mathrm{H}^{\prime}\right)$ & $\begin{array}{l}\mathrm{H} \times 41 \text {, where } 41 \text { is a unit conversion } \\
\text { factor }\end{array}$ & EPA 2002, Eq. (4-8) \\
\hline Soil organic carbon partition coefficient & Chemical-specific $\left(\mathrm{cm}^{3} / \mathrm{g}\right)$ & Appendix C \\
\hline Fraction organic carbon in soil & $0.006(\mathrm{~g} / \mathrm{g})$ & EPA 2002, Eq. (4-8) \\
\hline
\end{tabular}

Table D.7. Volatilization factor input parameters 